\title{
The uppermost Pleistocene-Holocene mud drape across the Marmara Sea: quantification of detrital supply from southern Marmara rivers
}

\author{
Hiscott R.N. ${ }^{1}$, Aksu A.E. ${ }^{1,{ }^{*}}$, Yaltırak C. ${ }^{2}$ \\ ${ }^{1}$ Earth Sciences Department, Memorial University of Newfoundland, St. John's, NL A1B 3X5, Canada \\ 2 Istanbul Technical University, Faculty of Mines, 80626 Maslak, Istanbul, Turkey \\ * Corresponding author : A. E. Aksu, email address : aaksu@mun.ca
}

\begin{abstract}
:
The Marmara Sea (area 11,350 km2; volume 3,378 km3; central basins $>1100 \mathrm{~m}$ deep) straddles the North Anatolian Transform Fault separating the Eurasian and Aegean-Anatolian tectonic plates. Along with the shallow straits of Dardanelles and Bosphorus (depths $\sim 63 \mathrm{~m}$ and $\sim 40 \mathrm{~m}$, respectively), the Marmara Sea forms the only marine connection between the Black Sea and the eastern Mediterranean. During Pleistocene glacial stages, the modern straits were subaerial valleys and the modern Marmara basin was occupied by the landlocked Propontis Lake. Previous researchers attributed major portions of a widely distributed uppermost Pleistocene-Holocene mud blanket (locally $>10-25 \mathrm{~m}$ thick; volume 43$47 \mathrm{~km} 3$ ) to transport of suspended load through one or both of the straits, as either the Aegean Sea (at $\sim 13.8 \mathrm{cal} \mathrm{ka}$ ) or the Neoeuxine Lake (today's Black Sea, at $\sim 11.1 \mathrm{cal} \mathrm{ka)} \mathrm{began} \mathrm{to} \mathrm{spill} \mathrm{into} \mathrm{the} \mathrm{Marmara}$ basin. To test these suggestions, the thicknesses and volume of the mud blanket were determined from $>5000$ line-km of airgun, sparker and boomer profiles and $>100$ cores, and compared with the contemporary supply from local rivers to decide, by difference, if the straits might have had a significant role. Volume calculations for the detrital supply from rivers rely on (1) decades of daily water- and sediment-discharge data from gauging stations, acquired before 20th century dam construction and, independently, (2) the BQART model which uses a variety of hydrological, geomorphic, geological and climate data. These calculations demonstrate that $>85-90 \%$ of the detritus in the offshore mud blanket was supplied by steep rivers (Kocasu River and its tributaries) and mountainous streams draining the highlands of the southern Marmara region. Geochemistry of the $<38 \mu \mathrm{m}$ fraction supports this source. Any input through the Dardanelles has been sporadic and limited to perhaps $\sim 5$ Gt of suspended load (equivalent to $\sim 5.2 \mathrm{~km} 3$ of porous mud when deposited) because of changing directions and rates of flow since the Last Glacial Maximum. Resedimentation through mass wasting and transgressive shoreface erosion appear to be minor compared with river supply. The isolated nature of the Marmara basin and its supply from mostly a single watershed afford an opportunity to verify the reliability of this type of hindcast analysis, based upon sediment-discharge data and catchment models - analysis which cannot be completed with a comparable level of certainty along open marine coastlines elsewhere.
\end{abstract}




\section{Highlights}

- Latest Pleistocene-Holocene Unit 1 forms a blanket of $43-47 \mathrm{~km}^{3}$ in Marmara Sea Kocasu River and its tributaries can account for $85-90 \%$ of the volume of Unit $1>$ Sediment budget calculations rely on data from gauging stations and BQART model - Isolated Marmara basins allow reliable quantification of the sedimentary budget

Keywords : marine sediment, mud, chemical analyses, sea-level changes, transgression, waterways 


\section{Introduction}

Geomorphologists, sedimentologists and stratigraphers have long sought to understand the various factors which control the rate of delivery of sediment from river drainage basins to the sea (Syvitski and Milliman, 2007, and references therein). These factors include area and relief of the drainage basin; climate as it controls soil development, vegetation cover and water discharge (both its average and extremes); bedrock composition (which controls erosion rate), and human perturbations to any of the above (e.g., deforestation, agricultural practices, damming

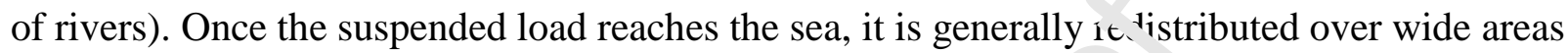

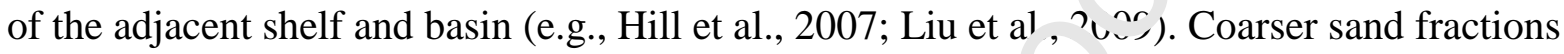
tend to be retained near the shore in littoral drift cells (War : $\mathrm{k}, 2020)$. Off-shelf transport is greatest when sealevel is at lowstands, although some riv o with direct access to the nearshore heads of modern submarine canyons may contin' $\epsilon^{t} \mathrm{ot}$ ansfer sediment into deep water even at highstands (e.g., Sakarya River, Algan et ‘’ , ग02; Congo River; Azpiroz-Zabala et al., 2017).

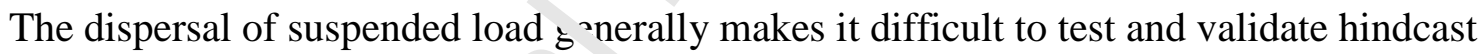
calculations and modelling results $f \sim r t \cdot e$ long-term sediment contributions of modern rivers. The small size and isolated natu ${ }^{2}$ of the Marmara Sea, western Turkey (Fig. 1) prevent escape of even the finest detritus. Thi $\mathrm{a}_{1}{ }^{\prime}$ ws quantification and tracking of the sediment supplied to its offshore since the rising i Tediterranean Sea breached the $\sim-75 \mathrm{~m}$ sill in the Strait of Dardanelles at $\sim 13.8 \mathrm{cal}$ ka (calibrated using Marine13 dataset). This sediment forms a mud blanket (or drape) locally $>10-20 \mathrm{~m}$ thick, the facies and biota of which are well known from previous studies (Table 1). The Kocasu River draining the Susurluk Drainage Basin (Fig. 2) (Kazanc1 et al., 2019) accounts for $\sim 80 \%$ of the freshwater and $\sim 90 \%$ of the suspended-sediment discharge to the Marmara Sea (Aksu et al., 1999). The remainder is almost entirely accounted for by the Biga and Gönen streams which also drain the southern Marmara region (Fig. 2). Small quantities of 
freshwater reach the sea via the Kemer creek near the Strait of Dardanelles, and via a number of mostly ephemeral streams which head north of the Marmara Sea, including the Ana, Kınıklı, Kula and Kurbağalıdere creeks (Fig. 1). None of these are significant sediment sources.

The tributaries of the Kocasu River (Fig. 2) have their own names (i.e., the Nilüfer, Orhaneli, Emet, Simav and Kocaçay branches). They coalesce to flow in a single channel through the Karacabey Gorge and into the Marmara Sea. Today, the Kocaçay and Emet branches have their seaward flow interrupted by the small Manyas and Ulua'u ${ }^{+}$Lakes, respectively, but this was not the case before $\sim 4.1$ cal ka (Kazanc1 et al., 2004) $11_{1} \ldots$ outaries have been dammed to varying degrees since $\sim 1985$ (with a few earlier exceptio.'s).

There has never been a quantitative study to asses whether the Susurluk Drainage Basin (i.e., Kocasu River and its tributaries) could have $F^{\circ} \mathrm{Jv}$ ded the bulk of the mud in the uppermost Pleistocene to Holocene drape across the ' 'ar' ara Sea. An alternative sediment supply through the straits of Dardanelles (Baştürk et al., 1986; Gökaşan et al., 2010) and Bosphorus (Aksu et al., 2016; Hiscott et al., 2017) has been ^dv $\leadsto$ ated, but never compared with the local river supply. Past detrital supply from the Sus rluk Drainage Basin can be reliably estimated for two main reasons: (1) there are numprnu :auging stations along the various tributaries of the Kocasu River (as well as the Göı`n and Biga streams), with records of daily water discharge over 30-60 years, as well as sediment-trap data to establish relationships between water discharge and suspended-sediment discharge; (2) although farming is practiced in the lowland area around the Manyas and Uluabat Lakes, the upland areas covering much of the inland portion of the drainage basin are forested with limited human disturbance (Google Earth ${ }^{\mathrm{TM}}$ satellite imagery acquired 30 December, 2016), so potentially experience erosion today as they did during the Holocene. With appropriate caveats, the enclosed nature of the Marmara basin might allow a quantitative 
comparison of the long-term sediment supply by rivers and streams of the Susurluk Drainage Basin to the post-13.8 cal ka mud drape. There is no reason to suspect loss of sediment through either the Strait of Dardanelles or Strait of Bosphorus (Fig. 1), which are narrow and presently are controlled by sills only $\sim 63 \mathrm{~m}$ and $\sim 40 \mathrm{~m}$ deep, respectively, with saline Mediterranean water moving northward along their floors since $\sim 13.8 \mathrm{cal} \mathrm{ka} \mathrm{(Dardanelles;} \mathrm{Aksu} \mathrm{et} \mathrm{al.,} \mathrm{2016)} \mathrm{and} ~ 9.4$ cal ka (Bosphorus; Yanchilina et al., 2017; Ankindinova et al., 2019).

In this study, we compare and contrast (1) the volume and $\mathrm{f}_{1 \mathrm{n}}{ }^{\mathrm{s}}$-fraction $(<38 \mu \mathrm{m})$ geochemistry of uppermost Pleistocene and Holocene sedime ${ }_{i t}{ }_{t} t_{\mu} u s i t e d$ across the shelves and basins of the Marmara Sea since its reconnection with the A 'gean Sea at $~ 13.8$ cal ka with (2) the volume of sediment supplied over this same time in+eı $t$ l by the Kocasu River and the Gönen and Biga streams draining the southern Marmarc $r_{2}$, ir, 1 , as well as the fine-fraction geochemistry of samples from the modern $\mathrm{r}_{\mathrm{c}}$ asu Delta. Other possible sediment sources are critiqued. The aim is to ascertain whethe rivers of the Susurluk Drainage Basin can account for the offshore mud drape.

\section{Setting}

The Marmara Sea is a $\sim 220 \mathrm{~km}$ long and $\sim 70 \mathrm{~km}$ wide east-west-trending inland depression, developed over the western extension of the North Anatolian Fault zone (Fig. 1). It has a surface area of $\sim 11,350 \mathrm{~km}^{2}$ and a water volume of $3,378 \mathrm{~km}^{3}$. The Marmara Sea is connected to the Black Sea and the Aegean Sea via the straits of Bosphorus and Dardanelles, respectively (Fig. 1). The Black Sea receives continental runoff from European rivers and exports $\sim 300 \mathrm{~km}^{3} \mathrm{yr}^{-1}$ of brackish water to the Marmara Sea and onward into the eastern Mediterranean Sea (Polat and Tuğrul, 1996; Özsoy et al., 2001). The present water exchange 
across both straits occurs as a two-layer flow. A cooler, lower salinity $(\mathrm{S}=17-20$ practical salinity units, hereafter unitless) surface layer 20-30 m thick exits the Black Sea and a warmer, higher salinity ( $\mathrm{S}=38-39$ ) layer of Mediterranean water flows northward through the straits at greater depths (Polat and Tuğrul, 1996; Özsoy et al., 2001). Shear between the upper and lower layers provides a mechanism to enhance sediment suspension and advection in the Marmara Sea, as does agitation under storm waves. Today, the Marmara Sea is subjected to frequent gale-force winds (Deniz et al., 2013), with 100-year storms generating $23.9 \mathrm{~m}_{\mathrm{r}} \mathrm{s}^{-1}$ (or $\sim 86 \mathrm{~km} \mathrm{hr}^{-1}$ ) winds (Öztunal1-Özbahçeci, 2020). Given the N-S fetch distance of 41, 7's km across the Marmara Sea, these 100-year storms can generate average wavelengı ` of 150-190 m (e.g., Thurman, 1988), with a storm wave base in the range 75-85 m (i.e., '.alf the wavelength; Garrison, 2005).

The Marmara Sea straddles an elongated i. ir e negative flower structure situated above a central master fault (e.g., Aksu et al., 20 9). Between the northern and southern shelves and steep fringing slopes, there are four cent..$^{1}$ basins separated by three intervening ridges. The western Tekirdağ and Central basir `ar $\bullet$ longate, southwest-trending rhombohedral depressions where water depths exceed $110 \_-12,0 \mathrm{~m}$ (Fig. 1). The easternmost Çınarcık Basin is a westnorthwest-trending elongat^ $a_{1} \sim$ ession with water depth $>1200 \mathrm{~m}$. The smaller and significantly shallower Kumburgaz $\mathrm{B}_{\mathfrak{c}}$ - in ( $~ 800 \mathrm{~m}$ deep) is situated on the broad southwest-trending ridge separating the Central and Çınarcık basins (Fig. 1). A fifth basin outside the central zone is a shallow ( $\sim 370 \mathrm{~m}$ deep), crescent-shaped depression perched high on the southern slope of the Çınarcık Basin, called the İmralı Basin (e.g., Sorlien et al., 2012). The three ridges which separate the Tekirdağ, Central and Çınarcık basins have water depths generally shallower than $600 \mathrm{~m}$. The shelf edge occurs at water depths of 90-100 m around the Marmara Sea, and very steep slopes of $10^{\circ}-30^{\circ}$ lead to the abyssal depths of the central basins. The northern shelf is 
narrow (3-10 km wide), whereas an approximately $20-30 \mathrm{~km}$-wide shelf occurs across the southern Marmara Sea (Fig. 1). The former is characterised by eroded Tertiary bedrock overlain by a very thin veneer of Holocene sediments, whereas the latter is characterised by a thick succession of Miocene-Recent stacked and north-prograded delta wedges (Aksu et al., 1999; Sorlien et al., 2012; Vardar et al., 2014).

The Marmara Sea experienced a lowstand from 25-13.8 cal ka (e.g., Aksu et al., 1999, 2016; Yaltirak et al., 2002), when the global ocean was lower than t. - floor of the Strait of Dardanelles (Lambeck et al., 2007). Lowstand terraces at $\sim-8 \mp \eta_{1}:$ 'evation (Çağatay et al., 2009) and down-stepping of southern shelf deltas to an - $70 \mathrm{~m}$ topset-foreset transition point (Aksu et al., 1999) pin the lowest stand of the Marmara $\mathrm{I}^{\prime}{ }^{\prime} \sim$ to an elevation of $\sim-85 \mathrm{~m}$ to $\sim-90$ $\mathrm{m}$, which is $10-15 \mathrm{~m}$ below the latest Pleistocen ${ }^{2} 1 \mathrm{e}$.evation of $-75 \mathrm{~m}$ in the Strait of Dardanelles (Aksu et al., 2016). The draw. nw.. of the lake level would only be possible if evaporation exceeded the input from loca' rivers and streams during the latest Pleistocene.

The Susurluk Drainage Basin ( $\left.5,000 \mathrm{~km}^{2}\right)$ consists of two distinct regions: (a) a rugged upland reaching elevations of $>\Sigma 500 \mathrm{~m}$ and drained by tributaries of the Kocasu River, and (b) a lowland depression $\left(\sim 106^{n}{ }^{n_{1}}{ }^{2}\right)$ confined on its northern side by Karadağ Mountain and an adjacent prominent line $\iota^{c}$ hills, with a single exit through the Karacabey Gorge (Kazanc1 et al., 2019) (Fig. 2). The depression has an elevation less than $+15 \mathrm{~m}$ and, today, is a swampy inland extension of the Kocasu delta plain (together, they cover $\sim 1350 \mathrm{~km}^{2}$ ). Through the latest Pleistocene and early Holocene, the depression was an area of bypass until the level of the Marmara Sea approached its current highstand at $~ 7.0 \mathrm{cal}$ ka (Lambeck et al., 2007). Subsequently, floodplain deposits started to infill the depression, and at $\sim 4.1$ cal ka (Kazanc1 et al., 2004) lacustine muds started to accumulate in what are now the Manyas and Uluabat Lakes. 
Late Holocene mini-deltas have developed where branches of the Kocasu system enter the lakes. Hence, these lakes have been traps for both bedload and some suspended load since $\sim 4.1 \mathrm{cal}$ ka. Kazanc1 et al. $(1999,2004)$ documented upper Holocene sediments $\sim 11 \mathrm{~m}$ thick and $\sim 8 \mathrm{~m}$ thick in the Manyas and Uluabat Lakes, respectively, as well as 5-40 m thick fluviatile sediments across the surrounding lowland depression.

The bedrock in the Susurluk Drainage Basin is extremely varied (Fig. 3). Ehrmann et al. (2007) attributed high proportions of smectite in the western Marma` Sea to weathering and erosion of the widespread volcanic rocks in the southern Marmara $r_{a}$ gion. Kazanc1 et al. (2014) linked high levels of boron in sediments of Lake Uluabat to valley incision into economic deposits crossed by the Emet branch of the Kocasu syste $\mathbf{l}_{\mathbf{L}}$ Although carbonates are not abundant in the Susurluk Drainage Basin, $\mathrm{CaCO}$; co ints for 6-7\% of the fine-grained infill of Lake Uluabat at core site LV 10 (Fig.2) (K эza .ıcı et al., 2014).

\section{Data and methods}

\subsection{Seismic reflection 1 -ofites and cores}

This paper is based $\sim \eta(n) \sim 3300$ line-km of single-channel airgun profiles with $\sim 135 \mathrm{~ms}$ $(\sim 100 \mathrm{~cm})$ vertical resolu "on and $\sim 100-300$ ms maximum penetration at shelf depths to $\sim 500$ 900 ms penetration in deep basins, (b) 1940 line-km of Huntec deep-tow-system (DTS) boomer/sparker profiles with $\sim 20-25 \mathrm{~ms}(\sim 15-20 \mathrm{~cm})$ vertical resolution and $\sim 20-40 \mathrm{~ms}$ maximum penetration at shelf depths to 50-90 ms penetration in deep basins, and (c) visual description of 74 gravity and 35 piston cores (Fig. 4). Piston cores were collected using a Mooring Systems Inc ${ }^{\mathrm{TM}}$ Kullenburg-type piston corer (original Benthos ${ }^{\mathrm{TM}}$ design) with split piston option, $1000 \mathrm{~kg}$ head weight, triggered $\sim 4.5 \mathrm{~m}$ above the sediment-water interface using a 
$50 \mathrm{~kg}$ trigger weight. Core-table descriptions recorded texture, colour (Geological Society of America, 1984), approximate carbonate content from reaction to $1 \mathrm{~N} \mathrm{HCl}$, physical sedimentary structures, bioturbation intensity, ichnotaxa wherever possible, mollusc and (rarely) echinoderm genus and species identity. The airgun profiles were acquired using a 40 cubic inch $\left(655 \mathrm{~cm}^{3}\right)$ sleeve gun with the reflections received by a 21 -element $9 \mathrm{~m}$ long streamer and filtered to 150 $1500 \mathrm{~Hz}$. The Huntec DTS profiles were collected using a $500 \mathrm{~J}$ boomer or periodically a $1000 \mathrm{~J}$ multi-tip sparker source, with echoes recorded using a single interria: hydrophone as well as a 21-element $6 \mathrm{~m}$ long streamer and filtered to 600-6000 Hz. N - riy.t.tional fixes from GPS (global positioning system) receivers were recorded every 10 minu . ${ }^{\text {s }}$ while surveying at a ship speed of $\sim 10 \mathrm{~km} \mathrm{hr}^{-1}$. The two-way travel time was converted to su "iment thickness using an acoustic velocity of $1500 \mathrm{~m} \mathrm{~s}^{-1}$ (consistent with Dal Forn r a d ' ' jasperini, 2008).

The volume of the uppermost Plei ner ne to Holocene Unit 1 was determined by tabulating and then contouring the thickı 'ss of the unit at each navigation fix (or fraction of a navigation fix where additional $\operatorname{det}^{\mathrm{i}} 1 \mathrm{v}, \mathrm{ar}$ needed). The contouring was done using two methods: (a) applying Global Mapper ${ }^{\mathrm{TM}} \mathrm{S}_{2}$ ftware to the xyz dataset (latitude, longitude, thickness) and (b)

hand-contouring in AutoC ${ }^{1} \cdot$ - iter the xyz data were imported into MapInfo ${ }^{\mathrm{TM}}$ and thicknesses placed at navigation poir $`$ as tags. In both cases the volume of sediments in Unit 1 was determined as a last step by Global Mapper ${ }^{\mathrm{TM}}$. The two methods differed in their volume estimates by $<5 \%$.

\subsection{Elemental composition of silt-to-clay fractions - laser ablation ICPMS}

To compare the Kocasu source and both shelf and basinal examples of Unit 1 muds, 38 medium-grained silt to clay samples $(<38 \mu \mathrm{m})$ were taken from cores acquired in 2002 , and 
seven samples were collected in 2017 on the subaerial top of the modern Kocasu Delta (samples M17-1 to M17-7; Fig. 2). The cores recovered typical Unit 1 facies (Table 1) so are not described here. Geographic coordinates, sample depths and ages of the deepest Unit 1 sample in each core are given in Supplementary material 1. Ages are based on calibrated radiocarbon dates (Supplementary material 2) and confirm that the samples come from Unit 1. At each sample depth, $\sim 25 \mathrm{~cm}^{3}$ of mud was extracted, treated with $10 \mathrm{~mL} 15 \% \mathrm{H}_{2} \mathrm{O}_{2}$ and wet-sieved through a $38 \mu \mathrm{m}$ sieve. The fine fractions were collected in $1 \mathrm{~L}$ beakers, and $\mathrm{u} \backslash$ s suspensions were flocculated using $20 \mathrm{~mL}$ of saturated $\mathrm{CaCl}_{2}$ solution. The exces wa..r was decanted and the residues were transferred into $500 \mathrm{~mL}$ beakers and acidifieu using $25-50 \mathrm{~mL} 10 \% \mathrm{HCl}$ to remove carbonates. The carbonate-free residues were rin is several times with settling accelerated using a centrifuge. They were oven $d n \cdot 1$ a $.40^{\circ} \mathrm{C}$ and powdered in the Memorial University of Newfoundland rock crushin far $_{\text {lity }}$ using titanium rings. The powdered samples were sent to Actlabs ${ }^{\mathrm{TM}}$ (Ancaster, Ontarn Canada) for the preparation of lithium borate glasses (or fused disks) for laser ablation i ${ }^{{ }^{-}{ }_{11}}$ ic ir ely coupled plasma mass spectrometry (LA-ICPMS) analyses. Small chips from each ' sticky tape. For the LA-ICDMA nalyses, a $193 \mathrm{~nm}$ ArF Excimer GeoLas ${ }^{\mathrm{TM}}$ laser system (Coherent, Germany) wa coupled to an Element XR ${ }^{\mathrm{TM}}$ (Thermo Fisher, Germany). The laser ablation system at Memorial University of Newfoundland is equipped with a cylindrical ablation cell with a volume of $\sim 10 \mathrm{~cm}^{3}$ capable of holding one sample slide at a time. NIST SRM 610 was used as the primary standard and BCR-2G as the secondary standard.

The laser was operated with a repetition rate of $4 \mathrm{~Hz}$, an energy density of $4 \mathrm{~J} \mathrm{~cm}^{-2}$ and five pre-ablation shots were carried out on each sample. Pre-ablation shots are used to remove the upper layer of each glass chip. The carrier gas flow was $1 \mathrm{~L} / \mathrm{min}$ He and the ICPMS was 
optimised for high sensitivity and a low oxide formation ratio (i.e., a $\mathrm{ThO}+/ \mathrm{Th}+$ ratio of $<0.2$ $\%)$. A crater size of $40 \mu \mathrm{m}$ was used during the ablations. In each sample, three spots were ablated. The concentrations of 55 elements (Al, Ag, As, Ba, Ca, Cd, Ce, Co, Cr, Cs, Cu, Dy, Er, $\mathrm{Eu}, \mathrm{Fe}, \mathrm{Ga}, \mathrm{Gd}, \mathrm{Ge}, \mathrm{Hf}, \mathrm{Ho}, \mathrm{In}, \mathrm{K}, \mathrm{La}, \mathrm{Lu}, \mathrm{Mg}, \mathrm{Mn}, \mathrm{Mo}, \mathrm{Na}, \mathrm{Nb}, \mathrm{Nd}, \mathrm{Ni}, \mathrm{P}, \mathrm{Pb}, \mathrm{Pr}, \mathrm{Pt}, \mathrm{Rb}, \mathrm{Re}$, Sb, Sc, Si, Sm, Sn, Sr, Ta, Tb, Th, Ti, Tm, U, V, W, Y, Yb, Zn, Zr) were measured.

\subsection{River and stream loads}

The Turkish General Directorate of Waterworks (EIE. 19, 2011) has collected daily water discharge and sediment load data at strategic points a. $n$ ng various tributaries since the 1950s. The EIE databases (EIE, 1982, 1987, 1993, 200n), rate water discharge (units $\mathrm{m}^{3} \mathrm{~s}^{-1}$ ) to suspended sediment load (units tonnes $\mathrm{day}^{-1}$ ), but. $\iota^{\natural} \mathrm{e}$ aly data which are useful for this study are from un-dammed water courses. Fortu. 'ate y, the EIE measurements started before post-1985 dam construction. The 1972-1985 data $1 \_$m the Gönen stream (147 measurements), the 19711990 data from the Kocaçay branch of $h$ r, Kocasu River (219 measurements) and the 1964-1979 data from the Emet branch (141 neasurements) pre-date damming, and allow fitting of best-fit curves which can be used to es tinate average loads of each watershed in the southern Marmara region (as tonnes $\mathrm{yr}^{-1}$ ) an ${ }^{1}$ long-term contributions to the offshore area. On log-log plots of water discharge versus sediment load, data points define trends which can be summarised by secondorder polynomial trends (Fig. 5), indicating that high-discharge events transport particularly high amounts of suspended sediment. Bedload is not accounted for in EIE datasets, so an increment is required to estimate the total sediment load. Data for similar watersheds elsewhere (e.g., Turowski et al., 2010) suggest an increment of $\sim 20 \%$, which has been applied in this study. 
Estimates of annual suspended-sediment contributions to Unit 1 from the Kocasu, Gönen and Biga watersheds were calculated using long-term records of daily discharges. Day-by-day conversions to sediment discharges capture as much short-term variation as possible, for example the high sediment loads characteristic of flood events. Daily water discharges were reduced to $67 \%$ of modern measurements before $11.7 \mathrm{cal}$ ka to acknowledge a drier climate during the Younger Dryas (Mudie et al., 2002a; Valsecchi et al., 2012). After accounting for bedload, the result (as solid mineral mass, in Gt) was reduced by 60,7 to recognise the loss of a significant amount of river detritus to floodplains and delta con the don before the remainder escapes to offshore, marine areas. The figure of $60 \%$ is froi Kukal (1971, p. 38), who argued that only $\sim 40 \%$ of the river supply successfully bypasses." contribute to contemporary marine successions.

A second, independent method of s stir ating sediment contributions from rivers and streams is provided by a global database $\mathrm{f}$ river loads and yields. Equation 1, from Syvitski and

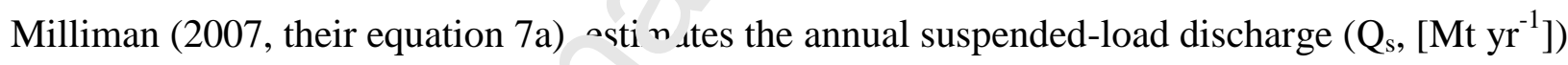
of a river when a number of para neters are known or can be reliably estimated. In situations without anthropogenic efferts, the difference between BQART estimates and directly measured values of annual load are $-5-7 \%$ of the estimate. The relationship is given by:

$$
\mathrm{Q}_{\mathrm{s}}=0.0006 \mathrm{~B} \mathrm{Q}^{0.31} \mathrm{~A}^{0.5} \mathrm{R} \mathrm{T}
$$

where B is a substrate factor set to 1.0 or 1.2 in the Susurluk Drainage Basin based on the bedrock composition (Konak, 2002; Türkecan and Yurtsever, 2002) (Fig. 3), Q is the annual water discharge $\left[\mathrm{km}^{3}\right], \mathrm{A}$ is the area of the drainage basin $\left[\mathrm{km}^{2}\right], \mathrm{R}$ is the maximum drainagebasin relief in headwater areas $[\mathrm{km}]$, and $\mathrm{T}$ is the annual average temperature $\left[{ }^{\circ} \mathrm{C}\right]$. Areas $(\mathrm{A})$ 
drained by individual branches of the Kocasu system and the Gönen and Biga streams were digitised from topographic maps; the maximum relief $(\mathrm{R})$ was measured in cross sections from upland areas acquired in Google Earth ${ }^{\mathrm{TM}}$ (December 30, 2016 imagery) using the pull-down menu Ruler $>$ Path $>$ Profile, and values of average annual temperature were taken from Vidal et al. (2010) and Valsecchi et al. (2012). As with calculations based on gauging-station data, daily water discharges were reduced to $67 \%$ of modern measurements before $11.7 \mathrm{cal} \mathrm{ka}$ to acknowledge a drier climate during the Younger Dryas (Mudie et á., 2002a; Valsecchi et al.,

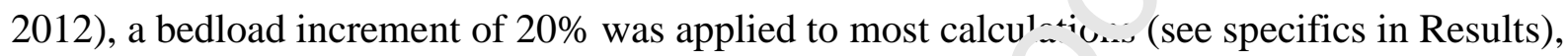
and only $40 \%$ of the resulting solid mass is estimated to hav a escaped the delta front to reach the open sea (and Unit 1 depocentres).

Comparison of river contributions to Unit, , ,er iment volumes requires conversion of solid mineral masses (in Gt, for river load.' to equivalent volumes of porous mud $\left(\mathrm{km}^{3}\right.$, consistent with seismic mapping of offsı $\checkmark$ re successions). We first converted the sediment loads [Gt] to solid volume $\left[\mathrm{km}^{3}\right]$ using ar $\mathrm{vv}^{\mathrm{v}}$ ge assumed grain density of $2.65 \mathrm{t} \mathrm{m}^{-3}$ (silicate bedrock), then expanded this to . notional equivalent volume of porous sediment having a porosity of $60 \%$, and finally in $\sim$ mented the result by an additional $10 \%$ to recognise the fact that marine Unit 1 contaı $\varsigma \sim 10 \%$ biogenic carbonate not supplied by rivers (e.g., nannofossils, foraminifera; Çağatay et al., 2000; Ergin et al., 2007). This is in addition to the $\sim 6-7 \%$ detrital carbonate carried in the suspended load of the Kocasu River (Kazanc1 et al., 2014). The 60\% porosity is directly calculated from measurements of bulk density reported by Dal Forno and Gasperini (2008) for core IM-05 acquired in $153 \mathrm{~m}$ of water $\sim 8 \mathrm{~km}$ east of İmralı Island (Fig. 4). There, Unit 1 is $\sim 2.4 \mathrm{~m}$ thick and bulk density is $1.7 \mathrm{t} \mathrm{m}^{-3}$. With a pore-water density of $1.028 \mathrm{t}$ 
$\mathrm{m}^{-3}$ and grain density of $2.67 \mathrm{t} \mathrm{m}^{-3}$ (silicates and minor carbonate), this value of bulk density translates to a porosity of $59 \%$.

\section{Results}

\subsection{Character and volume of uppermost Pleistocene to Holocene Unit 1}

This paper deals entirely with the uppermost Pleistocene to Holocene sedimentary unit which was deposited after saline Mediterranean water entered the Irs: rmara Sea at $\sim 13.8 \mathrm{cal}$ ka. Following Aksu et al. (1999), this is designated as Unit 1. The ₹ $\mathfrak{l}_{1} \approx$ unit has been recognised by Evans et al. (1989; their bioturbated muds), Wong et al. (15, 95 ; their unit 4), Smith et al. (1995; their unit A), Gökaşan et al. (2008, 2010, 2012; their unı ', Çağatay et al. (2000; their unit 1), Çağatay et al. (2009; their seismostratigraphic urit ' C', P1, lithologic unit L1), Eriş et al. (2007; their unit 1), Eriş et al. (2011; their seismc tra .graphic unit S1, lithologic unit L1), Eriş et al. (2012; their unit 2), Vardar et al. (2014, weir unit C3). Although authors have used different names in their publications (e.g., Ç řat v et al., 2000, 2009; Eriş et al., 2007, 2011, 2012) the descriptions and the basal ages a. signed to these units indicate that they are synonymous with the 'transparent' drape (i.e., Unit 1 , $\sim_{i}$ this paper (characteristics in Table 1). Unit 1 has also been recognised in Calypso gl 't piston cores acquired by the RV Marion Dufresne from the deep Marmara Sea basins as a marine hemipelagic unit overlying a pre-Holocene lacustrine succession (e.g., Beck et al., 2007, 2015; Campos et al., 2013). Above the -85 m level of the last lowstand, Unit 1 sits on a transgressive surface (called $\alpha 1$ ) which returns a strong, high amplitude reflection because of subaerial exposure during the lowstand. This simplifies mapping of the drape unit. In basinal areas, cores confirm the base of the post-transgressive mud with the arrival of euryhaline to stenohaline organisms like foraminifera, or chemical and mineralogical 
changes (e.g., calcite spike of Reichel and Halbach, 2007; see also Beck et al., 2015). On steep basin-margin slopes, Holocene sediments are thin or absent because of unstable conditions which promote sliding and other mass flow processes (Beck et al., 2007; Zitter et al., 2012).

Away from the modern coastline, from active deltas of the southern basin margin (Aksu et al., 1999; Hiscott and Aksu, 2002), from the Holocene outflow delta immediately south of the Strait of Bosphorus (Hiscott et al., 2002, 2007a; Aksu et al., 2016), and from the saline inflow channel at the eastern exit of the Strait of Dardanelles (Aksu et al., L`18), Unit 1 is characterised by laterally continuous, high-frequency, acoustically weak refl: $=l_{1}-\mathrm{s}$ (leading to a 'transparent' appearance) which can be traced in Huntec DTS profiles ac. nss shelf portions of the entire study area (Fig. 6). This internal seismic architecture suggests i. „Unit 1 is composed predominantly of fine-grained sediments with thin beds of slightly io rser or denser material.

Across the southwestern Marmara 'ea Unit 1 onlaps the prominent erosional unconformity $\alpha 1$ (Fig. 6). The hiatus at $\alpha^{1}$ must be several millennia wherever it is mapped at elevations shallower than $-75 \mathrm{~m}, \mathrm{~b}$ ^au $e$ the underlying successions had to be subaerially exposed at those localities since narme isotopic stage (MIS) 3 (ending $29 \mathrm{ka}$ ). This is the last time that the base level in the r.rmara basin could have exceeded the sill depth in the Strait of Dardanelles because the ise level in the Aegean Sea was in the vicinity of $-30 \mathrm{~m}$ to $-40 \mathrm{~m}$ (Skene et al., 1998; Svitoch et al., 2000).

An isopach map of Unit 1 (Fig. 7) allows the calculation of its volume (as sediment with water-filled pores). Graphic logs of Memorial University of Newfoundland cores (Fig. 8) and Marion Dufresne (Calypso) cores (Fig. 9) show the extent of thickness variations within Unit 1. Unit 1 is $15-25 \mathrm{~m}$ thick in the Tekirdağ, Central, Kumburgaz and Çınarcık basins along the central deep axis of the Marmara Sea (Figs. 7B, 9). It is equally thick within the İmralı Basin 
perched on the southeastern slope. Across the southern shelf, Unit 1 is distributed as a broadly east-west-trending, $>20 \mathrm{~m}$-thick narrow belt which encircles the present-day mouth of the Kocasu River and which shows evidence of progradational clinoforms in water depths less than $\sim 35 \mathrm{~m}$ (Vardar and Alpar, 2017, their fig. 5a). This lobe extends north and northwest for a considerable distance onto the southern Marmara shelf. Similar, but distinctly smaller and thinner prodelta lobes occur seaward of the mouths of the Gönen and Biga streams. Unit 1 is only $\sim 5 \mathrm{~m}$ thick in Gemlik Bay.

The thickness of Unit 1 varies from 7-15 $\mathrm{m}$ along the $r r_{i=2} \mathrm{n}$ and southern levées of the Dardanelles channel to $<5 \mathrm{~m}$ across the northwestern portic: of the Strait of Dardanelles (Fig. 7B) (Aksu et al., 2018). It is thickest along the northern lc ee where Unit 1 defines narrow, broadly east-west-trending, elongated lobes witl c atr 1 thicknesses locally exceeding $25 \mathrm{~m}$. Similar narrow, but thinner lobes $(15-20$ i’') a'so occur along the southern levée. Unlike broad areas of the middle and outer shelves, thc -e is an internal unconformity (d-unconformity, Fig. 10) within Unit 1 in both levées of the $\operatorname{Prc}{ }^{2}$.elles channel, and the top of the unit is truncated along the northern side of the channel. These relationships suggest a more complex post-13.8 cal ka history of sedimentation in thl ? ea, with possible implications for significant sediment supply to Unit 1 .

Atypical Unit 1 facies are also present at the southern exit of the Bosphorus Strait in the northeastern Marmara Sea. An older part of the unit (11.1-10.2 cal ka) constitutes an early Holocene mid-shelf delta characterised in Huntec DTS profiles by an elongate, lobate plan view shape and a climbing topset-foreset transition (Fig. 11). This deltaic wedge has a volume of $\sim 0.53 \mathrm{~km}^{3}$ and is sandwiched between the oldest muds of Unit 1 (between reflectors $\beta 3$ and $\beta 2$ of Aksu et al., 2016) and the post-delta Holocene drape ( $\beta 1$ to seabed, Fig. 11). This lobe 
developed as a result of vigorous Black Sea outflow through the strait (Aksu et al., 2016; Hiscott et al., 2017), and must have introduced prodelta mud at least to that local area and perhaps to the nearby Çınarcık Basin (Fig. 1). If $60 \%$ of the load of the Bosphorus outflow was retained in the delta itself (Kukal, 1971), the offshore contribution would have been rather small, at $\sim 0.35 \mathrm{~km}^{3}$.

For the purpose of a comparison between the volume of post-13.8 cal ka sediment across the Marmara Sea and the sediment contributions of the Kocasu River and the Gönen and Biga streams, the Marmara Sea and the Kocasu delta plain can be divideu into five depositional domains: (1) the southern shelf, (2) the southwestern Marmar $\mathrm{Ce}_{\mathrm{m}}$ it the entrance to the Strait of Dardanelles, (3) the northern shelf, including the early to $m_{\text {. }}$-ddle Holocene mid-shelf delta at the Bosphorus exit, (4) the deep basins beyond the shelf edgt .nd (5) the Manyas and Uluabat Lakes situated in the low-lying region south of Karada 7A). Except for the finest clay-sized partic es 'n long-term suspension by waves, there is no sediment pathway between the southern : Tarmara water courses and the northern shelf, including the vicinity of the Bosphorus exit ( $\sigma_{.} ., \Delta$ su et al., 2016).

The entire volume of pos -13.8 cal ka water-saturated sediment in the Marmara basin exclusive of the northern sholi $\cdots d$ Bosphorus exit (thus domains 1,2 and 4) is estimated to be $45.0 \mathrm{~km}^{3}$ (Table 2). Unce tanty is expected to be of the order of about $\pm 5 \%$, so a reasonable range for this volume is $43-47 \mathrm{~km}^{3}$. The Manyas and Uluabat Lakes have accumulated an additional $1.1 \mathrm{~km}^{3}$ (Table 2).

\subsection{Quantity of detritus provided by Kocasu, Gönen and Biga watersheds}

Two approaches to the quantification of sediment supply from rivers and streams along the southern margin of the Marmara Sea are considered: (1) utilisation of data from gauging 
stations on the Kocasu River and the Gönen and Biga streams to calculate long-term sediment supply, based on the assumption that latest Pleistocene to Holocene sediment loads of the various rivers and streams can be estimated from modern relationships (Fig. 5), and (2) application of the BQART model of Syvitski and Milliman (2007).

\subsubsection{River supply using data from gauging stations}

The Kocasu River and the Gönen and Biga streams are the $\mathrm{V}_{1}{ }^{1} \mathrm{~V}$ significant point sources in the Marmara Sea, with the Kocasu River dominating the ser:m_... and water discharges. The equivalent volumes of porous sediment expected from thes water courses, using pre-dam relationships (Fig. 5), are presented in Table 3 as sums nv . three time intervals: (a) 13.8-7.0 cal $\mathrm{ka}$ (transgression) when all load from the four $\mathrm{K} x{ }^{\prime}, \mathrm{u}$ ributaries and from the Biga and Gönen streams escaped the river mouths, (b) 7.0- 1 al ka (early highstand) when only $40 \%$ of the load from all watersheds is hypothesised to ha'e reached the open sea as the remainder constructed delta lobes and aggraded low-eleva*: on $\mathrm{fl}^{\mathrm{l}}$ Jodplains, and (c) 4.1-0.0 cal ka (highstand) when no bedload from the Kocaçay, Emt. and Orhaneli tributaries reached the sea, but other water courses continued to provida $L^{\prime} 140 \%$ of their suspended load and $40 \%$ or their bedload. By this time, a portion of the bec' ad fraction would have likely remained in nearshore and shelf transport (Warrick, 2020) while the muddy suspended load would have more readily moved offshore to the outer shelf or deep basins.

Decades of data have been incorporated to improve the estimate of average annual suspended loads (e.g., 55 years of Kocaçay data $=20,075$ conversions of water discharge to suspended-load discharge). Based on the scenarios explained above, the Kocasu, Gönen and Biga contributions of suspended load and bedload since 13.8 cal ka total $\sim 4.3 \mathrm{~km}^{3}$ (Table 3). 
More than $95 \%$ of this is attributed to the Kocasu River and its tributaries (i.e., the Susurluk Drainage Basin). This is essentially identical to the $45.0 \mathrm{~km}^{3}$ (with uncertainty, $43-47 \mathrm{~km}^{3}$ ) required to account for Unit 1 in the Marmara Sea (Table 2).

Furthermore, calculations suggest fthat $14.0-16.8 \mathrm{~km}^{3}$ of sediment were retained in floodplain and delta top settings, assuming in this case a porosity of 40-50\% more typical of continental deposits (Manger, 1963). This can be tested against the measured volume around the Manyas and Uluabat Lakes and in the modern Kocasu Delta and its r rodelta. If $14.0-16.8 \mathrm{~km}^{3}$ of sediment were retained in this area since $\sim 7.0 \mathrm{cal} \mathrm{ka}$, when se $10_{V}: 1$. reached a near-modern elevation, the average sediment thickness over an area of $1.50 \mathrm{~km}^{2}$ would be $\sim 10.4-12.5 \mathrm{~m}$. This range is very reasonable based on what is known about sc "iment thicknesses in the southern Marmara onshore region (Kazanc1 et al., 2019).

\subsubsection{River supply using BQA↔T equation of Syvitski and Milliman (2007)}

Using the same temporal $c^{-n} \operatorname{str}^{-i}$, ts that were imposed on calculations based on gaugingstation data, the BQART procea. re gives a total sediment supply of $38.31 \pm 2.68 \mathrm{~km}^{3}$ over the last $13.8 \mathrm{cal} \mathrm{ka}$ (Table 4), with $-2.2-14.7 \mathrm{~km}^{3}$ retained on land and in the subaerial portion of the highstand Kocasu De ${ }^{+}$a. This is $86 \%$ of the amount calculated independently using data from modern gauging stations, and strongly supports those results, although in detail the BQART estimates are less than those using station data for most tributaries of the Kocasu River, and are larger for the Nilüfer, Biga, Gönen and Keçi streams (Tables 3, 4). In the remainder of the paper, the $13.8-0.0$ cal ka sediment supply from rivers and streams of the southern Marmara region is set to $40 \mathrm{~km}^{3}$ to simplify interpretations and discussion, and individual tributary and stream 
values are taken to be averages of estimates in Tables 3 and 4. Uncertainty in the total supply is probably at least $5 \%$ of $40 \mathrm{~km}^{3}$, so notionally $\pm 2 \mathrm{~km}^{3}$ of porous mud.

\subsubsection{Fine-fraction geochemical linkages, Kocasu Delta to deep basins}

Volumes aside, erosion products of the Susurluk Drainage Basin should have a composition consistent with Unit 1 muds to strengthen the case for a source-to-sink linkage. Given the dearth of sand in offshore portions of the mud drape, a ge -hemical approach has been selected. An exact match in the abundances and ratios of elem ants = nnnot be expected for several reasons: (1) although all samples consist of $<38 \mu \mathrm{m}$ silt anc -lay, the samples surely have different proportions of coarse, medium and fine silt and $\downarrow$ y, so likely different adsorption characteristics for certain chemical elements; (2) t $\mathrm{t} \cdot \mathrm{m}$. odern samples from the subaerial Kocasu Delta are probably contaminated due to ag. "cr itural fertilisers and industry in the watershed; (3) in some cases there is considerable scatte, in elemental abundances at single core sites, so although the source and sink may $r_{*} \cdot \cdots$ erlapping ranges for particular elements, the mean values may not correspond. For ' 'ese reasons, comparison of the seven Kocasu Delta samples to the offshore shelf and dee overlapping 95\% confide. ce intervals for mean abundances, and in many cases simply an indication that abundances are in the same range.

LA-ICPMS data are available in Supplementary Material 3, except for platinum which showed a high degree of scatter attributed to the use of platinum crucibles for the preparation of the fused disks. Mean values were calculated for (a) the Kocasu delta top, (b) the western shelf drape (cores M02-103P and M02-106P) and (c) deep basins (cores M02-88P, M02-89P, M0290P, M02-102P). The averages were then sorted from smallest to largest (for the Kocasu set; 
Table 5) and plotted as pairs of $\log _{10}$ values to assess how closely the pairs of delta and marine values follow a straight line (Fig. 12). For both the western shelf and the deep basinal cores, linear regression coefficients $\left(\mathrm{R}^{2}\right)$ exceed 0.97 . This suggests an overall good similarity of mean values across the spectrum of elements, although matches for a few elements are poor (e.g., As, $\mathrm{P}, \mathrm{Sb}$, Mo in deep basin samples, and to some extent $\mathrm{Cu}$ and W) (Fig. 12). Arsenic is also high in modern sediments of Uluabat Lake (Katip et al., 2012) and its elevated level in delta-top samples M17-1 to M17-2 is similarily interpreted as an anthropogenic effec. Antimony ( $\mathrm{Sb}$ ) likewise is probably high in modern samples because of use in industry $a^{\text {nd }}$ a a culture (Li et al., 2018).

As a second approach, $95 \%$ confidence intervals aru ind means for the Kocasu Delta samples versus (a) shelf samples and (b) basins samples v. ie calculated with the objective of looking for overlapping confidence intervals as $\mathrm{in}$ : idi :ator of good correspondence between means. This is similar to, but not as string $n t ?$ a two-tailed student t-test with the null hypothesis of equality of mean values (e.- Tan and Tan, 2010) but our goal is to demonstrate general similarities between groups $\sim f:{ }^{2}$..ples, not that all samples are from the same population. Overlap of $95 \%$ con idence intervals characterises 17 minor, trace and rare-earth elements when the delta sampi $\cdots$ are compared with all marine samples (shelf and deep basin samples together) and an 'dditional nine elements if delta and shelf fine fractions are considered alone (Table 5). For Kocasu Delta and shelf silt-clay samples alone (i.e., cores M02-103P and M02-106P), 15 of the 47 minor, trace and rare-earth elements have statistically indistinguishable means using a 2-tailed student t-test and the assumption of unequal variances.

Overall, there is nothing in the geochemical data to suggest that the Unit 1 silts and clays could not have been derived entirely from the suspended load of the Kocasu River, but neither is there a strong tracer element to prove this linkage. Kazanc1 et al. (2014) point to boron as a 
possible tracer because there are economic borate deposits currently mined in the Emet watershed, and boron concentrations in lacustrine muds of Uluabat Lake sharply increase 1000 years ago. However, lithium borate flux was used in the preparation of LA-ICPMS fused glasses, so boron is not in our dataset. Also, the vast majority of the Unit 1 drape is older than 1000 CE.

Molybdenum is 28 times more abundant in the average of basinal cores than in shelf cores M02-103P and M02-106P (Fig. 12 outlier). Otherwise there is only one difference marginally greater than a factor of two. Samples of Unit 1 from the $\mathrm{c}$ ?rly Holocene outflow delta at the southern exit of the Strait of Bosphorus have not been ir $\approx 1_{1} L_{-\perp}$ in this study because of coarser mean grain size, some problems with authigenic $\mathrm{gy}_{\mathrm{F}}$ sum raising $\mathrm{Ca}$ abundances in several samples, and poor similarity to samples at our $\mathrm{o}^{+} \mathrm{h}$ - sites, particularly for $\operatorname{Re}(57 \times$ multiplier), $\mathrm{Cd}(15 \times$ multiplier $), \mathrm{Sb}(13 \times$ multiplieı, ar $\mathrm{d}$ As $(7 \times$ multiplier $)$ (see data in Supplementary Material 3). However, avern? - Mo is 116× more abundant in the area of the Bosphorus exit than elsewhere in Unit 1 (a rerage of 38 shelf and basin samples), and 1670× more abundant than in our 15 shel sanples alone. None of these samples are younger than $\sim 2.5$ cal ka, so apparently elevated $\wedge_{0}: s$ a primary source characteristic of detritus from the Bosphorus outflow.

\subsubsection{Denudation rate}

Table 4, column 5 provides areas for the watersheds contributing to each gauging station. These areas pertain to the steeper upstream areas away from the lowland depression occupied by the Manyas and Uluabat Lakes, and were obtained using Global Mapper ${ }^{\mathrm{TM}}$ software. The denudation rate for the study area can be estimated from the summed solid volumes of suspended and bedload (Table 4, with $20 \%$ increment for bedload and a grain density of $2.65 \mathrm{~kg} \mathrm{~m}^{-3}$ ) 
divided by the total watershed area and duration of erosion (13,800 years). The results are slightly different for gauging-station volumes and BQART estimates, but fall in the range of $0.05-0.06 \mathrm{~mm} \mathrm{yr}^{-1}$. This is far less than rates for steep watersheds with high annual rainfall in Japan (Sueoka et al., 2016) where denudation rates can locally reach $\sim 10 \mathrm{~mm} \mathrm{yr}^{-1}$. The lower rate in the Susurluk Drainage Basin results from a drier climate.

\section{Interpretation}

The volume of uppermost Pleistocene to Holocene sed: $m_{t_{2} . \pm}$ (13.8-0.0 cal ka) buried across the southern Marmara shelf $\left(9.09 \mathrm{~km}^{3}\right.$; Table 2) can $\cdot$ e accounted for by the Kocasu River $\left(\sim 38.0 \mathrm{~km}^{3}\right.$ as porous equivalent, averaging gauging-statı , and BQART results). However, the Gönen and Biga streams (contribution of $\sim 3.3 \mathrm{~km}$ qv valent since $13.8 \mathrm{cal} \mathrm{ka}$ ) cannot account for the volume of contemporaneous sedim $\cdot n t s$ in the southwestern Marmara region near the entrance to the Strait of Dardanelles (4.5- $\mathrm{km}^{3}$, Table 2). Some of the mud in that domain must have been imported from elsewhere - $\epsilon$ tr.er from the Kocasu system which appears to have generated an excess supply or fi. $m$ the initial entry of Aegean water through the Strait of Dardanelles at the time of the : $r$ t reconnection of the Marmara Sea to the global ocean (Section 6.2).

The deep Marmara basins contain $\sim 31.4 \mathrm{~km}^{3}$ of uppermost Pleistocene to Holocene sediments (Table 2). Based solely on mean values, if it is assumed that the Kocasu, Gönen and Biga sediment loads (averaged across Tables 3 and 4) first fully accounted for deposits on the southern and southwestern shelves, then there might be the possibility of a deficit in supply of $\sim 3.5 \mathrm{~km}^{3}$ in the deep basins since $13.8 \mathrm{cal} \mathrm{ka}$. 
Uncertainties are likely in the calculations, stemming from the underlying assumptions, which might be sufficient to explain the apparent mismatch in riverine supply versus Unit 1 volumes. In this study, modern relationships between sediment loads of rivers and water discharges have been extrapolated back to $13.8 \mathrm{cal} \mathrm{ka}$. However, there is good evidence from around Turkey that $20^{\text {th }}$ century erosion rates are several times higher than previous rates because of intensive agriculture and urban development (Atalay, 1984; Özsoy et al., 2012). This would affect the equations used to calculate sediment loads if the wa'ar courses involved were in areas of intensive land use, but would increase rather than decmas .tie apparent mismatch in sediment volumes if pre-historical sediment yields were lov ar than today. Fortunately, the gauging stations for this study (Fig. 2) are close to the up . eam, forested and little-developed parts of the various watersheds. It is implicit in the 'se of modern water and sediment discharges that the climate, in particular rainfall, has , tt v aried significantly through the Holocene (whereas Younger Dryas dryness is incorporated $1_{1}$. 0 calculations; Tables 3, 4). Although some

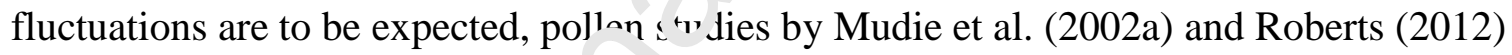
suggest persistent relatively waı $\urcorner$ and wet conditions in the region by $\sim 9.7$ cal ka and stability in these aspects of the climat hy $\because .5 \mathrm{cal}$ ka. If the period 13.8-9.7 cal ka was somewhat drier than assumed in the calculativ: 's of this study, then the possible deficit of supply to the central basins would be higher, not lower, than calculations suggest.

The fact that gauging station calculations (Table 3) seem to agree, within uncertainty, with the mapped volumes of Unit 1 (Table 2) should not be taken as proof that no other sources of silt and clay existed through the latest Pleistocene and Holocene. Certain critical assumptions on how to translate suspended-load detritus (in Gt) into equivalent volumes of porous marine sediment could be sufficiently incorrect to widen the disagreement between apparent supply and 
the Unit 1 volume. The volume itself, calculated from seismic profiles, could be an underestimate. Strict adherence to a porosity of $60 \%$, biogenic carbonate content of $10 \%$, and retention of $60 \%$ of river load in floodplains and highstand deltas (Kukal, 1971) can all be questioned, certainly in detail. However, from what is known about marine muds (Kominz et al., 2011), the present average porosity is not likely to be lower than $60 \%$, and anything higher than $60 \%$ would reduce (or even reverse) the already small difference in volume estimates between Kocasu, Gönen and Biga output and Unit 1. The same porosity, calc `nate requirement and onland retention were applied to BQART estimates of sediment. surply (Table 4), yet those are $\sim 15 \%$ lower than the estimates based on gauging station res.tionships. Although no single parameter can explain the differences between Tables $3 a_{2}: 4$, it is our view that an estimate in the lower range of gauging station results makes $\mathrm{n}$ - st ,ense, and that the post-13.8 cal ka contribution from the Susurluk Drainage L asi ‘ and Gönen and Biga watersheds was likely in the range of $38-40 \mathrm{~km}^{3}$ (at a notional porosı.' of $60 \%$ incremented by $10 \%$ biogenic carbonate introduced offshore).

\section{Discussion}

The primary reası $\urcorner$ tor insisting on a deficiency in supply from rivers alone is that there are several other processes which must have contributed fine-grained sediment, even if the river supply was dominant. The deep central basins contain thick post-reconnection deposits (Figs. 7B, 9) with ubiquitous muddy turbidites and homogenites attesting to seismically-induced failures of portions of the very steep slopes which encircle these areas (e.g., Beck et al., 2007, 2015; Eriş et al., 2012; Zitter et al., 2012; Campos, 2014). Any material mobilised in this way from Pleistocene and older deposits would not be accounted for by the calculations targeting 
contemporaneous river supply. Roberts (2012) documents common presence and several spikes in reworked pre-Quaternary dinoflagellate cysts (600-1200 cysts $\left.\mathrm{g}^{-1}\right)$ and pollen in core M0289P from the İmralı Basin, confirming some input from older seafloor erosion and failures.

Another potential source for sediment in the deep basins is lateral transfer of detritus from the lowstand shelves during the 13.8-7.0 cal ka transgression. This process is called transgressive shoreface erosion, or ravinement (Swift, 1968). Ravinement depends on energetic waves to carve up to several metres of shoreface deposits away as in shoreline sweeps landward. Modern storm wave base at $\sim-75$ to $85 \mathrm{~m}$ (Section ?) , sumpatible with shoreface erosion, but the burial of pristine sand waves and delta lobc: on parts of the southern shelf (Aksu et al., 1999) suggests minor downcutting during the lates -ieistocene to early Holocene transgression.

\subsection{Possible Bosphorus contrib.tions}

A possible sediment source $\urcorner \mathrm{t} 1$ 1 , t from $\sim 11.1-6.0 \mathrm{cal} \mathrm{ka}$, is outflow from the Black Sea through the Strait of Bosphorus. The strait carried bedload in a one-way flow until $\sim 10.2$ cal ka (Aksu et al., 2016; Hiscott $\wedge^{+}$á. $^{\prime}$ 2017) and then suspended load until $\sim 6.0$ cal ka as a salt wedge penetrated, at depth, into 'he strait, presaging the eventual full penetration of a bottom-hugging saline density current into the Black Sea by 9.4 cal ka (Flood et al., 2009; Ankindinova et al., 2019).

The majority of the Unit 1 mud drape is younger than 10.2 cal ka when the Black Sea outflow started to weaken as indicated by abandonment of the climbing delta at the southern exit of the Strait of Bosphorus (Fig. 11). It is therefore likely that only small amounts of detritus introduced by Holocene Bosphorus outflow reached central and western parts of the Marmara 
Sea to contribute to the Unit 1 mud drape. Based on the volume of the delta lobe itself, the offshore contribution might have been $\sim 0.35-0.50 \mathrm{~km}^{3}$ (Section 4.1). Nevertheless, the Mo signature of deep basinal muds in this study (Fig. 12, average $20.8 \mu \mathrm{g} \mathrm{g}^{-1}$ ) is consistent with the high Mo abundances in the silts and muds of the Holocene drape overlying the outflow delta itself (average $1243 \mu \mathrm{g} \mathrm{g}^{-1}$ for 10 samples, but as high as $3715 \mu \mathrm{g} \mathrm{g}^{-1}$ in M02-110P samples with an age of $\sim 8.3 \mathrm{cal} \mathrm{ka}$ ). A dedicated study based on deep basinal cores in the Çınarcık Basin would be required to investigate the extent of this source-to-sink relatinship.

\subsection{Possible Dardanelles contributions}

Baştürk et al. (1986) calculated the suspended-s $s d_{1 .}$ nent discharge into the Marmara Sea

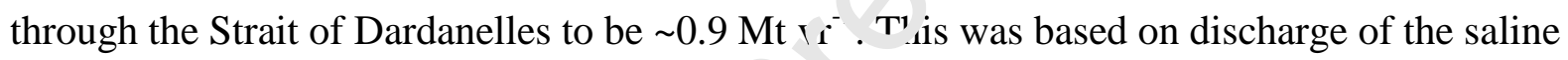
lower layer and the quantity of suspended $s$ ment in water samples, captured on $1.2 \mu \mathrm{m}$ filter papers during a limited number of casts in March, April and July of 1986. We do not find the sampling frequency nor density to $u$ uniicient for strong conclusions, and are somewhat skeptical because no rivers or 'ary ' streams enter the strait to provide suspended material to the Aegean inflow. Also, ther a a $:$ ields of bioherms across most of the floor and at the northern end of the strait, in water up tc $60 \mathrm{~m}$ deep (Aksu et al., 2018), constructed in part by coralline red algae which require diffuse sunlight to survive (i.e., relatively clear water well down into the saline lower layer). Nevertheless, we assess the possible impact of a sediment contribution of $\sim 0.9 \mathrm{Mt} \mathrm{yr}^{-1}$ below.

Melting of the Scandinavian ice sheet after the Last Glacial Maximum caused meltwater to spill from the Neoeuxine Lake (today's Black Sea), through the Propontis Lake (today's Marmara Sea) to the Aegean Sea (Grosswald, 1980; Tudryn et al., 2016; Yanchilina et al., 2019). 
The overspill occurred $~ 17.2-15.7$ cal ka (Tudryn et al., 2016). Then, the sill at the northern end of the Strait of Dardanelles had an elevation of -76 to -77 m (Aksu et al., 2016) so the level of the Propontis Lake must have been somewhat higher, say -75 to $-73 \mathrm{~m}$. The Aegean Sea was significantly lower at -120 m (Lambeck et al., 2014). The level of the Propontis Lake then fell to -85 $\mathrm{m}$ when outflow from the Neoeuxine Lake ceased and net evaporation ensued (Aksu et al., 1999), resulting in isolation of the lake from the Aegean Sea.

Gökaşan et al. (2010) argued that the subsequent entry of $A c_{\varepsilon}^{-e a n}$ water into the lowstand Marmara basin (starting $13.8 \mathrm{cal}$ ka according to Aksu et al., $2 \Omega^{1} \mathrm{U}$, _arried large amounts of detritus eroded from the floor of the former Dardanelles vai' $y$. Because of the large difference in density between this Aegean inflow and the fresh to $h_{l}$. kish waters of the pre-reconnection Propontis Lake, the initial inflow likely descendra s s a underflow into the westernmost Tekirdağ Basin, confining its sediment co trir ation to that basin. The spill depth between the Tekirdağ Basin and the Central Basin is $\mathrm{u}^{+}$an elevation of $-710 \mathrm{~m}$, below which the Tekirda $\breve{g}$ Basin has a volume of $\sim 105 \mathrm{~km}^{3}$. This rume is sufficient to have retained $\sim 75 \%$ of the dense, inspilling Aegean seawater neecid to equalise the water levels of the Aegean and Marmara seas.

The initial inflow of $A_{2}$ _an surface water into the Marmara basin through the Strait of Dardanelles likely introa``ed sediment (Gökaşan et al., 2010). However, that inflow would have ceased once the level of the Marmara Sea rose to coincide with the level in the Aegean Sea, because there was no connection to the Neoeuxine Lake at this time. The level of the Propontis Lake immediately before entry of Aegean water was about $-85 \mathrm{~m}$, and its level by $13.2 \mathrm{cal} \mathrm{ka}$ was no shallower than $-60 \mathrm{~m}$ (Lambeck et al., 2007). The volume of Aegean Sea water needed to raise the base level from $-85 \mathrm{~m}$ to $-60 \mathrm{~m}$ is $\sim 140 \mathrm{~km}^{3}$, which is one-quarter to one-sixth of today's annual northward bottom flow (Polat and Tuğrul, 1996). At the time of first entry of 
saline water the cross-sectional area of the strait would have been much less than today, so the flow velocity and erosional potential might have been greater. The $\alpha 1$ unconformity marking the base of Unit 1 where the Dardanelles inflow channel enters the Marmara Sea (Fig. 10) might have been created by scour during this event. The lower portion of Unit 1 (i.e., the sediments between the $\alpha 1$ unconformity and the $d$ reflector, Fig. 10) potentially accumulated atop this scoured surface as the initial inflow waned and as water level rose to coincide with the level in the Aegean Sea.

The incoming seawater had to overtop a sill located at the _... thern end of the strait (Aksu et al., 2016, their fig. 3a). Because the strait deepens by $\sim 2 \mathrm{~m}$ on the Aegean side of this point, erosion would have been limited to the area of the sill itsc ${ }^{16}$, and the descent from the sill to the lowstand Marmara shoreline, then $\sim 30 \mathrm{~km}$ away. $\sim \mathrm{IV} f \mathrm{n}$ the modest water volume $\left(\sim 140 \mathrm{~km}^{3}\right)$ and the short distance, the volume of sedii. ' $\mathrm{n}^{\prime}$ mobilised by the initial entry was likely considerably smaller than suggested by $\subset$ ökaşan et al. (2010). If the suspended sediment concentration had been $1200 \mathrm{mg} \mathrm{L}^{-1}(0) .12 \mathrm{Gt} \mathrm{km}^{-3}$ ), which is high for rivers in flood (e.g., Blanchard et al., 2011; Ellison $\epsilon_{\text {. }}$ ll., 2014) and double the typical wet-season concentration for mountainous tributaries of the 1 nazon River (Gibbs, 1967), then the $140 \mathrm{~km}^{3}$ of Aegean inflow would have transported $\iota 1 /$ Gt of detritus into the Tekirdağ Basin, equivalent at $60 \%$ porosity and $10 \%$ biogenic carbonate to only $0.18 \mathrm{~km}^{3}$ of porous sediment.

After the equalisation of water levels, saline Aegean water probably continued to flow, albeit more slowly, into the Marmara basin (a) because of its density contrast with the preexisting brackish water mass and (b) to replenish evaporative losses. This slow inflow expelled and replaced $2740 \mathrm{~km}^{3}$ of brackish water remaining from the lacustrine phase; at $10 \%$ of today's rate of inflow (so $\sim 70 \mathrm{~km}^{3} \mathrm{yr}^{-1}$ ) the replacement might have taken $\sim 40$ years to complete. 
The Kocasu, Gönen and Biga watersheds only supply fresh water at $\sim 5.2 \mathrm{~km}^{3} \mathrm{yr}^{-1}$, so would not have significantly delayed the salination.

From 13.2-11.1 cal ka, the Marmara Sea remained an embayment of the Mediterranean Sea, with full marine salinity (Table 6). The $d$ reflector in the mud-prone levées at the eastern exit of the Strait of Dardanelles (Fig. 10) possibly records reduced sedimentation during stagnation of exchange at this time (i.e., little inflow or outflow). Subsequently, the rising Neoeuxine Lake began to export brackish water down the Bosphoru. valley (Aksu et al., 2016), across the Marmara Sea and through the Dardanelles, but with no ¿a. urn flow because saline water had not yet gained access to the Neoeuxine Lake. Th southward flow through both straits was one-way only, so opposite to the situation from $\sim 13 . \imath \quad 13.2 \mathrm{cal}$ ka (Table 6). The unidirectional outflow might have controlled dero ic 1 of the uppermost portion of Unit 1 above the $d$ reflector (Fig. 10). This situat: $\urcorner$ r r ontinued until $\sim 9.5 \mathrm{cal}$ ka when the first saline water began to enter the Neoeuxine Lakt.'Black Sea (Major et al., 2006; Yanchilina et al., 2017; Ankindinova et al., 2019). Sustaine ${ }^{\lambda}$ th $~$ way flow along the Strait of Bosphorus began later at $\sim 8.0$ cal ka (Hiscott et al., 2007८, and it is only then that the northward flow of saline water along the floor of the Strait $n t$ rdanelles might have become competent to transport $\sim 0.9 \mathrm{Mt}$ $\mathrm{yr}^{-1}$ of suspended sedime. ${ }^{+}$into the Marmara basin (Baştürk et al., 1986) and to cause the erosion seen in the modern walls of the Dardanelles channel (i.e., the $\alpha 0$ unconformity, Fig. 10). Integrated over 8,000 years, this flux would have been able to bring $~ 7.2 \mathrm{Gt}$ of suspended sediment into the western Marmara Sea. As explained above, we believe this estimate is too large given other constraints, so $5 \mathrm{Gt}$ might be a more realistic maximum, which is equivalent to $\sim 5.2 \mathrm{~km}^{3}$ of porous marine mud. A Dardanelles input of this amount, and only since $\sim 8.0 \mathrm{cal} \mathrm{ka}$, is $~ 12 \%$ of the $43-47 \mathrm{~km}^{3}$ of siliciclastic detritus in Unit 1 (Table 2). 


\section{Conclusions}

The uppermost Quaternary, post-transgressive mud drape in the Marmara Sea provides a rare opportunity to quantitatively compare the supply of detritus from specific rivers and streams to the volume of material dispersed to offshore shelves and basins. More commonly, fine material of this calibre is advected far offshore and alongshore so that it cannot be confidently tracked backward to its source. In this study, sediment supply from ivers and streams along the southern margin of the Marmara Sea is estimated in two ways $\cdot 1, \ldots . .1 n g$ hydrographic measurements of water and suspended-sediment discharge, ver several decades in these watersheds, and (2) using a multivariate model developec " ur a large number of rivers worldwide (BQART model), taking into consideration the a*e. re ief and geology of the watersheds, climatic regime, and average water discha. re. The predicted sediment supply since reconnection of the Marmara basin to the global ocean १t $\sim 13.8$ cal ka approaches what is needed to account for all the coeval muddy Unit 1 acr $\sim s_{\text {i }}$ f modern marine shelves and basins, surpassing 85$90 \%$ of the requirement. Althou ${ }_{z}$ h otner sediment sources must have been active, this study strongly suggests their limita a ${ }^{\circ}$ ntribution. These include: (a) products of shoreface erosion during the $-85 \mathrm{~m}$ to $0 \mathrm{~m}$. ansgression; (b) episodic transport of detritus through the Strait of Dardanelles (13.8-13.2 cal ka; 8.0-0 cal ka); (c) early Holocene supply of detritus through the Strait of Bosphorus, and (d) failure of older slope material adding to deep basin successions.

The application of a cap of $40 \%$ on the amount of river-borne detritus available to marine areas fits nicely with reasonable estimates of the volume of latest Quaternary floodplain and lacustrine deposits in the lower part of the Susurluk Drainage Basin, around the Manyas and Uluabat Lakes. If the sequestering of $60 \%$ of river load in floodplains and delta lobes had not 
been specified in calculations, the post-13.8 cal ka supply would have significantly exceeded the volume of contemporary marine mud.

For the first time, the detrital input through the Strait of Dardanelles has been critically evaluated based on the complex history of flow in that waterway (both changing magnitude and direction). Unconformity-bounded sedimentary wedges beneath the banks of the Dardanelles channel as it enters the Marmara Sea are tentatively assigned to five distinct phases of flow: (1) 13.8-13.2 cal ka erosion producing the late Pleistocene $\alpha 1$ unconfur rity; (2) accumulation of lenticular levée wedges under waning inflow from the Aegear. S $^{s_{a}}$ us the water level in the Marmara Sea approached the level of the global ocean; (3) ¿ velopment of an hiatus ( 13.2-11.1 cal ka) and minor unconformity ( $d$ reflector) when the Ma.nara Sea was a marine embayment of the Aegean Sea with limited water exchange in $\epsilon$ it. $r$ irection; (4) accumulation of the uppermost levée wedges under westward-८ ‘re _ted outflow toward the Aegean Sea, 11.1-8.0 cal

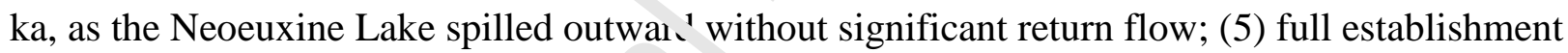
of two-way flow in both straits so $t^{1}+1=$ bottom water in the Strait of Dardanelles now moves persistently northeastward, wide. ing the saline inflow channel (Fig. 10) and locally truncating older strata along its bankr.

The primary objec ive of explaining the origin of the thick mostly Holocene mud drape in the tectonically active Marmara Sea has been addressed successfully, with relatively steep rivers and streams of the southern margin contributing the majority of the detritus. Further coring and dating will be necessary to test hypotheses advanced here on the origin of wedges of sediment beneath the banks of the submarine channel at the northeastern exit of the Strait of Dardanelles.

\section{Acknowledgments}


We thank the officers and crew of the RV Koca Piri Reis, particularly the former Captains M. Özsaygılı and K. Dursun and the former Chief Engineers B. Nuriler and Ö. Çubuk for their invaluable assistance during the 1995, 1997, 1998, 2000, 2002, 2008, 2011 and 2014 geophysical and coring operations. We further thank Dr. D. Yaşar of the Institute of Marine Sciences and Technology, Dokuz Eylül University, for his role in facilitating these cruises. Dr. D. Tezcan kindly assisted the authors by obtaining copies of out-of-print oceanographic reports critical to the research. We thank the Natural Sciences and Enginetring Research Council of Canada (NSERC) for Shiptime and Discovery Grants to AEA $=n$ a n...NH. Two anonymous reviewers and the journal editor Catherine Chagué helped l. ^authors focus their arguments and improve the overall presentation. 


\section{References}

Abrajano, T., Aksu, A.E., Hiscott, R.N., Mudie, P.J., 2002. Aspects of carbon isotope biogeochemistry of late Quaternary sediments from the Marmara Sea and Black Sea. Marine Geology 190, 151-164.

Aksu, A.E., Hiscott, R.N., Yaşar, D., 1999. Oscillating Quaternary water levels of the Marmara Sea and vigorous outflow into the Aegean Sea from the Marmara Sea-Black Sea drainage corridor. Marine Geology 153, 275-302.

Aksu, A.E., Calon, T., Hiscott, R.N., Yaşar, D, 2000. Anatom $n_{1} \ldots$ … North Anatolian Fault Zone in the Marmara Sea, western Turkey: extensic.'əl basins above a continental transform. GSA Today June 2000, 3-7.

Aksu, A.E., Hiscott, R.N., Kaminski, M.A., Muric P. ., Gillespie, H., Abrajano, T., Yaşar, D., 2002. Last glacial - Holocene pale rer .ıgraphy of the Black Sea and Marmara Sea: stable isotopic, foraminiferal ana vocolith evidence. Marine Geology 190, 119-149.

Aksu, A.E., Hiscott, R.N., Yaltırak C., $\Upsilon$ $r 16$. Early Holocene age and provenance of a mid-shelf delta lobe south of the Sᄂ ait of Bosphorus, Turkey, and its links to vigorous Black Sea outflow. Marine Genloe: 380, 113-137.

Aksu, A.E., Hiscott, R.N. Kostylev, V.E., Yaltırak, C., 2018. Organized patches of bioherm growth where the Strait of Dardanelles enters the Marmara Sea, Turkey. Palaeogeography, Palaeoclimatology, Palaeoecology 490, 325-346.

Algan, O., Gökaşan, E., Gazioğlu, C., Yücel, Z.Y., Alpar, B., Güneysu, C., Kirci, E., Demirel, S., Sar1, E., Ongan, D., 2002. A high-resolution seismic study in Sakarya delta and submarine canyon, southern Black Sea shelf. Continental Shelf Research 22, 1511-1527. 
Aloisi, G., Soulet, G., Henry, P., Wallmann, K., Sauvestre, R., Vallet-Coulomb, C., Lécuyer, C., Bard, E., 2015. Freshening of the Marmara Sea prior to its post-glacial reconnection to the Mediterranean Sea. Earth and Planetary Science Letters 413, 176-185.

Ankindinova, O., Hiscott, R.N., Aksu, A.E., Grimes, V., 2019. Strontium isotopic composition of shells from the Black Sea and implications for the reconnection with the global ocean. Marine Geology 407, 213-228.

Atalay, I., 1984. Soil erosion and its effects on the transportation aic the modern sedimentation in Turkey. Ege Coğrafya Dergisi 2, 31-47.

Azpiroz-Zabala, M., Cartigny, M.J.B., Talling, P.J., Parson. D.R., Sumner, E.J., Clare, M.A., Simmons, S.M., Cooper, C., Pope, E.L., 2017. Ne . iy recognized turbidity current structure can explain prolonged flushing ot ' ab narine canyons. Science Advances 3, e1700200, doi: 10.1126/sciadv.17C $120 \mathrm{~J}$.

Baştürk, Ö, Saydam, A.C., Salihoğlu, İ., Vilmaz, A. 1986. Oceanography of the Turkish Straits, Vol. III: Health of the Strait ${ }^{\text {r }}$ II $r$,hemical and Environmental Aspects of the Sea of Marmara. Institute of Ma ine s̃ciences, METU, Erdemli-İçel, Turkey, First Annual Report, 96 pp.

Bayhan, E., Ergin, M., ' I nel, A., Keskin, S., 2001. Sedimentology and mineralogy of surficial bottom deposits from the Aegean-Canakkale-Marmara transition (Eastern Mediterranean): effects of marine and terrestrial factors. Marine Geology 175, 297-315. Beck, C. de Lépinay, B.M., Schneider, J-L., Cremer, M., Çağatay, N., Wendenbaum, E., Boutareaud, S., Ménot, G., Schmidt, S., Weber, O., Eris, K., Armijo, R., Meyer, B., Pondard, N., Gutscher, M-A., the MARMACORE Cruise Party 2007. Late Quaternary 
co-seismic sedimentation in the Sea of Marmara's deep basins. Sedimentary Geology 199, $65-89$.

Beck, C., Campos, C., Eriş, K.K., Çağatay, N., de Lepinay, B.M., Jouanne, F., 2015. Estimation of successive coseismic vertical offsets using coeval sedimentary events - application to the southwestern limit of the Sea of Marmara's Central Basin (North Anatolian Fault). Natural Hazards and Earth System Sciences 15, 247-259.

Blanchard, R.A., Ellison, C.A., Galloway, J.M., Evans, D.A., 2011. ^ediment Concentrations, Loads, and Particle-Size Distributions in the Red River $+\ldots$ North and Selected Tributaries near Fargo, North Dakota, during the 26:n Spring High-Flow Event. U.S. Geological Survey Scientific Investigations Repoı: ¿011-5064, 27 pp.

Büyükmeriç, Y., 2016. Postglacial floodings of the Ms imara Sea: molluscs and sediments tell the story. Geo-Marine Letters 36, _ 17- 321.

Çağatay, N.M., Görür, N., Algan, O., Ea``oe, E., Tchapalyga, A., Ongan, D., Kuhne, T., Kuşcu, I., 2000. Late Glacial-Holor n€ $n$, laeoceanography of the Sea of Marmara: timing of connections with the Me'iterranean and the Black Seas. Marine Geology 167, 191-206.

Çağatay, N.M., Eriş, K., Rıran, v.B.F., Sancar, Ü. Polonia, A., Akçer, S., Biltekin, D., Gasperini, L., Go *ir, N., Lericolais, G., Bard, E., 2009. Late Pleistocene-Holocene evolution of the northern shelf of the Sea of Marmara. Marine Geology 265, 87-100.

Campos, C., 2014. Comparative Study of Co-Seismic Sedimentation in Two Tectonically Active Areas: the Sea of Marmara and the Gulf of Corinth. Methodological Developments, Implication for Seismic Hazards Assessment (Ph.D. thesis). Grenoble University, 248 pp.

Campos, C., Beck, C., Crouzet, C., Demory, F., Van Welden, A., Eriş, K., 2013. Deciphering hemipelagites from homogenites through anisotropy of magnetic susceptibility. 
Paleoseismic implications (Sea of Marmara and Gulf of Corinth). Sedimentary Geology $292,1-14$.

Dal Forno, G., Gasperini, L., 2008. ChirCor: A new tool for generating synthetic chirp-sonar seismograms. Computers and Geosciences 34, 103-114.

Deniz, A., Özdemir, E.T., Sezen, I, Coşkun, M., 2013. Investigations of storms in the region of Marmara in Turkey. Theoretical Applied Climatology 112, 61-71.

Ehrmann, W., Schmiedl, G., Hamann, Y., Kuhut, T., 2007. Distribui nn of clay minerals in surface sediment of the Aegean Sea: a compilation. Int_ancis unal Journal of Earth Sciences (Geologische Rundschau) 96, 769-780.

EIE, 1950-2011. Elektrik İşleri Etüt İdaresi Genel Direkı ıügü (General Directorate of Waterworks). Water Year Discharges, Arn' d ' ' 'atalogues published in years 1950 to 2011 by EIE, Ankara, Turkey. 195 · (4 • pp), 1951 (48 pp), 1952 (63 pp), 1953 (190 pp), 1954 (110 pp), 1955 (115 pp), 1५こ5 (119 pp), 1956 (115 pp), 1958 (129 pp), 1959 (102 pp), 1960 (103 pp), 1961 (9 np! 1962 (141 pp), 1963 (167 pp), 1964 (192 pp), 1965 (212 pp), 1966 (221 pp), 196 / (208 pp), 1968 (204 pp), 1969 (214 pp), 1970 (211 pp), 1971 (215 pp), 1979 (_. 17 pp), 1973 (207 pp), 1974 (206 pp), 1975 (186 pp), 1976 (186 pp), 1977 (186 pp， 1978 (189 pp), 1979 (192 pp), 1980 (190 pp), 1981 (205 pp), 1982 (206 pp), 1983 (206 pp), 1984 (205 pp), 1985 (207 pp), 1986 (203 pp), 1987 (204 pp), 1988 (209 pp), 1989 (209 pp), 1990 (208 pp), 1991 (205 pp), 1992 (210 pp), 1993 (224 pp), 1994 (220 pp), 1995 (219 pp), 1996 (227 pp), 1997 (229 pp), 1998 (234 pp), 1999 (228 pp), 2000 (230 pp), 2001 (277 pp), 2002 (227 pp), 2003 (219 pp), 2004 (220 pp), 2005 (219 pp), 2006 (226 pp), 2007 (239 pp), 2008 (236 pp), 2009 (249 pp), 2010 (443 pp), 2011 (417 pp) (in Turkish). 
EIE, 1982, 1987, 1993, 2000. Elektrik İşleri Etüt İdaresi Genel Direktörlüğü (General

Directorate of Waterworks). Türkiye Akarsularında Sediment Gözlemleri ve Sediment Taşınım Miktarları (Sediment data and sediment transport amount for surface water in Turkey). Catalogues published in 1982 (82-22; 283 pp.), 1987 (87-44; 495 pp.), 1993 (93-59; 615 pp) and 2000 (20-17; 617 pp) by EIE, Ankara, Turkey (in Turkish).

Ellison, C.A., Savage, B.E., Johnson, G.D., 2014. Suspended-Sediment Concentrations, Loads, Total Suspended Solids, Turbidity, and Particle-Size Fractivı- for Selected Rivers in Minnesota, 2007 through 2011. U.S. Geological Surver Su: 2013-5205, 43 pp., http://dx.doi.org/10.3133/sir201.25205.

Ergin, M., Bodur, M.N., 1999. Silt/clay fractionation in su icial Marmara sediments: implication for water movement and sediment transpor, sat as in a semi-enclosed and two-layered flow system (northeastern Mediter. ne „n Sea). Geo-Marine Letters 18, 225-233.

Ergin, M., Uluadam, E., Sarıkavak, K., L’`skin, Ş., Gökaşan, E., Tur, H., 2007. Late Quaternary sedimentation and tectonics in t.e submarine Şarköy Canyon, western Marmara Sea (Turkey). In: Taymaz, T., Yılınaz, Y., Dilek, Y. (Eds.), The Geodynamics of the Aegean and Anatolia. Geoln ric.'1 Society London, Special Publication 291, pp. 231-257.

Eriş, K.K., Ryan, W.B.F., Çağatay, M.N., Sancar, U., Lericolais, G., Ménot, G., Bard, E., 2007. The timing and evolution of the post-glacial transgression across the Sea of Marmara shelf south of İstanbul. Marine Geology 243, 57-76.

Eriş, K.K., Çağatay, N., Akçer, S., Gaperini, L., Mart, Y., 2011. Late glacial to Holocene sealevel changes in the Sea of Marmara: new evidence from high-resolution seismics and core studies. Geo-Marine Letters 31, 1-18. 
Eriş, K.K., Çağatay, N., Beck, C., de Lépinay, M.B., Campos, C., 2012. Late-Pleistocene to Holocene sedimentary fills of the Çinarcik Basin of the Sea of Marmara. Sedimentary Geology 281, 151-165.

Evans, G., Erten, H., Alavri, S.N., Von Gunten, H.R., Ergin, M., 1989. Superficial deep-water sediments of the eastern Marmara basin. Geo-Marine Letters 9, 27-36.

Flood, R.D., Hiscott, R.N., Aksu, A.E., 2009. Morphology and evolution of an anastomosed channel network where saline underflow enters the Black Sen Sedimentology 56, 807839.

Garrison, T., 2005. Oceanography: An Invitation to Marint Science, 5th edition. Thomson Brooks/Cole, Pacific Grove, CA, 522 pp.

Geological Society of America, 1984. Rock Colrr 'na t. Rock-color chart committee (representing the U.S. Geological s ' rrv 4 y, Geological Society of America, the American Association of Petroleum Geolog: 'ts, the Society of Economic Geologists, the Association of American Stre ('e slogists). Geological Society of America, Boulder, CO.

Gibbs, R.J., 1967. The geochem, try of the Amazon River system: part I. The factors that control the salinity and the $n_{1 .}^{n}$ ssition and concentration of the suspended solids. Geological Society of Amerı? Bulletin 78, 1203-1232.

Gökaşan, E., Ergin, M., Özyalvaç, M., Sur, H.İ., Tur, H., Görüm, T, Ustaömer, T, Batuk, F.G., Alp, H., Birkan, H., Türker, A., Gezgin, E., Özturan, Ö., 2008. Factors controlling the morphological evolution of the Çanakkale Strait (Dardanelles, Turkey). Geo-Marine Letters 28, 107-129.

Gökaşan, E., Tur, H., Ergin, M., Görüm, T., Batuk, F.G., Sağc1, N., Ustaömer, T., Emem, O., Alp, H., 2010. Late Quaternary evolution of the Çanakkale Strait region (Dardanelles, 
NW Turkey): implications of a major erosional event for the postglacial MediterraneanMarmara Sea connection. Geo-Marine Letters 30, 113-131.

Gökaşan, E., Görüm, T., Tur, H., Batuk, F., 2012. Morpho-tectonic evolution of the Çanakkale Basin (NW Anatolia): evidence for a recent tectonic inversion from transpression to transtension Geo-Marine Letters 32, 227-239.

Grosswald, M.G., 1980. Late Weichselian ice sheet of Northern Europe. Quaternary Research $13,1-32$.

Hill, P.S., Fox, J.M., Crockett, J.S., Curran, K.J., Friedrichs, C. T , Zıyer, W.R., Milligan, T.G., Ogston, A.S., Puig, P., Scully, M.E., Traykovski, P.` ., Wheatcroft, R.A., 2007. Sediment delivery to the seabed on continental margins. In: "'*ittrouer, C.A., Austin, J.A., Field, M.E., Kravitz, J.H., Syvitski, J.P.M., Wire, _, P.L. (Eds.), Continental Margin Sedimentation: from Sediment Tra.' $s \mathrm{p}^{\prime}, \mathrm{rt}$ to Sequence Stratigraphy. International Association of Sedimentologists, 7xford, pp. 49-97.

Hiscott, R.N., Aksu, A.E., 2002. L" ${ }^{\text {to }}$ ("ternary history of the Marmara Sea and Black Sea from high-resolution seis. nic and gravity core studies. Marine Geology 190, 261-282.

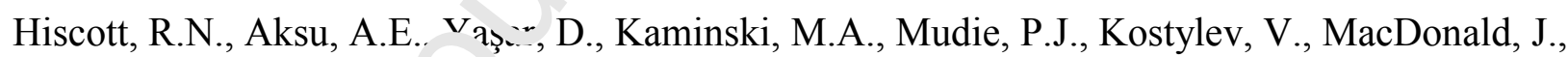
Işler, F.I., Lord, 5 R., 2002. Deltas south of the Bosphorus Strait record persistent Black Sea outflow to the Marmara Sea since $10 \mathrm{ka}$. Marine Geology 190, 95-118.

Hiscott, R.N., Aksu, A.E., Mudie, P.J., Kaminski, M.A., Abrajano, T., Yaşar, D., Rochon, A., 2007a. The Marmara Sea Gateway since 16 ka: non-catastrophic causes of paleoceanographic events in the Black Sea at 8.4 ka and 7.15 ka. In: Yanko-Hombach, V., Gilbert, A.S., Panin, N., Dolukhanov, P.M. (Eds.), The Black Sea Flood Question: 
Changes in Coastline, Climate, and Human Settlement. Springer, Dordrecht, The Netherlands, pp. 89-117.

Hiscott, R.N., Aksu, A.E., Mudie, P.J., Marret, F., Abrajano, T., Kaminski, M.A., Evans, J., Çakıroğlu, A., Yaşar, D., 2007b. A gradual drowning of the southwestern Black Sea shelf: evidence for a progressive rather than abrupt Holocene reconnection with the eastern Mediterranean Sea through the Marmara Sea Gateway. Quaternary International 167-168, 19-34.

Hiscott, R.N., Aksu, A.E., Yaltırak, C., 2017. Modelling the pmvannce of detritus flushed through the Strait of Bosphorus, Turkey, during ear, ${ }^{\prime}$ Holocene outflow from the Black Sea to the world ocean. Marine Geology 390, 14, : : $: 9$.

Intergovernmental Oceanographic Commission $\left./ I^{\prime}-\right)$ 1981. International Bathymetric Chart of the Mediterranean. Published by th $\cdot \mathrm{H}$ ad Department of Navigation and Oceanography, Russia under the authority of IOC, 10 sheets.

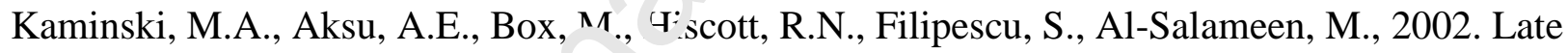
glacial to Holocene benti : ${ }^{c}$ foraminifera in the Marmara Sea: implications for Black SeaMediterranean Sea $\mathrm{nth}^{\circ}$ :tions following the last deglaciation. Marine Geology 190, $165-202$.

Katip, A., Karaer, F., Ileri, S., Sarmasik, S., Aydoğan, N., Zenginay, S., 2012. Analysis and assessment of trace elements pollution in sediments of Lake Uluabat, Turkey. Journal of Environmental Biology 33, 961-968.

Kazanc1, N., Emre, Ö., Erkal, T., İleri, Ö., Ergin, M. Görür, N., 1999. Morphology and sedimentary facies of modern Kocasu and Gönen rivers deltas, northwestern Anatolia. Mineral Research and Exploration Bulletin 121, 1-18. 
Kazanc1, N., Leroy, S.A.G., İleri, Ö., Emre, Ö, Kibar, M. Öncel, S., 2004. Late Holocene erosion in NW Anatolia from sediments of Lake Manyas, Lake Uluabat and the southern shelf of the Marmara Sea, Turkey. Catena 57, 277-308.

Kazanc1, N., Emre, Ö, Erturaç, K., Leroy, S.A.G., Öncel, S., Ileri, Ö, Toprak, Ö, 2014. Possible incision time of the large valleys in southern Marmara region, NW Turkey. Bulletin of the Mineral Research and Exploration 148, 1-17.

Kazancı, N., Ergun, Z., İren, K., Leroy, S.A.G., Boyraz Arslan, S., C’ncel, S., Koç, K., Gürbüz, A., 2019. Late Quaternary landscape evolution of the paleogeographic implications for settlements, NW i rrkey. Turkish Journal of Earth Sciences 28, 479-499.

Kominz, M., Patterson, K., Odette, D., 2011. Lith' ${ }^{1}$ Jg' dependence of porosity in slope and deep marine sediment. Journal of Sedim 'nt $:$ y Research 81, 730-742.

Konak, N., 2002. Geological Map of Tuı'rey, İzmir Map Sheet, General Directorate of Mineral Research and Exploration (MT 1 Ankara, Turkey, 1:500,000 scale.

Kukal, Z., 1971. Geology of Re` ’nt Sediments. Academic Press, London, 490 pp.

Lambeck, K., Sivan, D., Pיrct.1 A., 2007. Timing of the last Mediterranean Sea - Black Sea connection from .. istatic models and regional sea-level data. In: Yanko-Hombach, V., Gilbert, A.S., Panin, N., Dolukhanov, P.M. (Eds.), The Black Sea Flood Question: Changes in Coastline, Climate and Human Settlement. Springer, The Netherlands, pp. 797-808.

Lambeck, K., Rouby, H., Purcell, A., Sun, Y., Sambridge, M., 2014. Sea level and global ice volumes from the Last Glacial Maximum to the Holocene. Proceedings of the National Academy of Sciences of the United States of America 111, 15296-15303. 
Li, J., Zheng, B., He, Y., Zhou, Y., Chen, X., Ruan, S., Yang, Y., Dai, C., Tang, L., 2018.

Antimony contamination, consequences and removal techniques: a review. Ecotoxicology and Environmental Safety 156, 125-134.

Liu, J.P., Xue, Z., Ross, K., Wang, H.J., Yang, Z.S., Li, A.C., Gao, S., 2009. Fate of sediments delivered to the sea by Asian large rivers: long-distance transport and formation of remote alongshore clinothems. The Sedimentary Record 7, 4-9.

Londeix, L., Herreyre, Y., Turon, J-L., Fletcher, W., 2009. Last Gla '^l to Holocene hydrology of the Marmara Sea inferred from dinoflagellate cyst record $n:$. 1ew of Palaeobotany and Palynology 158, 52-71.

Major, C., Goldstein, S., Ryan, W., Lericolais, G., Piotrov ,ki, A.M., Hajdas, I., 2006. The coevolution of Black Sea level and compos ${ }^{-1}$ or through the last deglaciation and its paleoclimatic significance. Quater. ary s̀cience Reviews 25, 2031-2047.

Manger, G.E., 1963. Porosity and Bulk L’ansity of Sedimentary Rocks. Contributions to

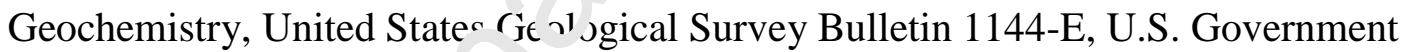
Printing Office, Washing on L.C., 55 pp.

McHugh, C.M.G., Gurung, ワ., Ciosan, L., Ryan, W.B.F., Mart, Y., Sancar, U., Burckle, L., Çağatay, M.N., 2008. The last reconnection of the Marmara Sea (Turkey) to the World Ocean: A paleoceanographic and paleoclimatic perspective. Marine Geology 255, 64-82. Mudie, P.J., Rochon, A., Aksu, A.E., 2002a. Pollen stratigraphy of Late Quaternary cores from Marmara Sea: land-sea correlation and paleoclimatic history. Marine Geology 190, 233260. 
Mudie, P.J., Rochon, A., Aksu, A.E., Gillespie, H., 2002b. Dinoflagellate cysts and freshwater algae and fungal spores as salinity indicators in Late Quaternary cores from Marmara and Black Seas. Marine Geology 190, 203-231.

Özsoy, E., Di Iorio, D., Gregg, M., Backhaus, J.O., 2001. Mixing in the Bosphorus Strait and the Black Sea continental shelf: observations and a model of the dense water outflow. Journal of Marine Systems 31, 99-135.

Özsoy, G., Aksoy, E., Dirim, M.S., Tumsavas, Z., 2012. Determinalinn of soil erosion risk in the Mustafakemalpasa River Basin, Turkey, using the revis: ‘ _...iversal soil loss equation, geographic information system, and remote sensing. Environmental Management 50, $679-694$.

Öztunal1-Özbahçeci, B., 2020. Extreme value strsti ${ }^{+} \mathrm{cs}$ of wind speed and wave height of the Marmara Sea based on combined r. dar altimeter data. Advances in Space Research 66, 2302-2318.

Polat, Ç., Tuğrul, S., 1996. Chemic ${ }^{-1} \mathrm{e}^{-1}$ lange between the Mediterranean and Black Sea via the Turkish Straits. In: Brian` ' F. (Ed.), Dynamics of Mediterranean Straits and Channels.

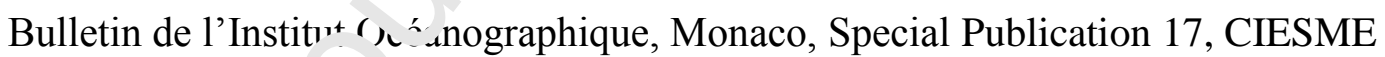
Science Series 2, ^ ๆ. 167-186.

Rangin, C., Demirbağ, E., Imren, C., Crusson, A., Normand, A., Le Drezen, E., Le Bot, A., 2001. Marine Atlas of the Sea of Marmara (Turkey). Ifremer, Plouzane, France, 15 pp, 11 plates.

Reichel, T., Halbach, P., 2007. An authigenic calcite layer in the sediments of the Sea of Marmara - a geochemical marker horizon with paleoceanographic significance. Deep-Sea Research II 54, 1201-1215. 
Roberts, K., 2012. Paleoenvironment of Marmara Sea: Palynology of Upper Pleistocene Holocene Sediments in Long Piston Cores (M.Sc. thesis). Memorial University of Newfoundland, St. John's, 162 pp.

Ryan, W.B.F., Carbotte, S.M., Coplan, J.O., O'Hara, S., Melkonian, A., Arko, R., Weissel, R.A., Ferrini, V., Goodwillie, A., Nitsche, F., Bonczkowski, J., Zemsky, R., 2009. Global multiresolution topography synthesis. Geochemistry, Geophysics, Geosystems 10, Q03014, doi:10.1029/2008GC002332.

Skene, K.I., Piper, D.J.W., Aksu, A.E., Syvitski, J.P.M., 1998 F、_.'.ation of the global oxygen isotope curve as a proxy for Quaternary sea level by modeling of delta progradation. Journal of Sedimentary Research 68, 1077-1092.

Smith, A.D., Taymaz, T., Oktay, F., Yüce, H., A'p’`, , ., Başaran, H., Jackson, J.A., Kara, S., Şimşek, M., 1995. High-resolutior eir mic profiling in the Sea of Marmara (northwest Turkey): late Quaternary sedimeı' 'ation and sea-level changes. Bulletin of the Geological Society of America 107, 922 -9:6

Sorlien, C.C., Akhun, S.D., Seeı `r, L., Steckler,M., Shillington, D., Kurt, H., Çifçi, G., Poyraz, D.T., Gürçay, S., P^nc. ‘..r, D., İmren, C., Perinçek, E., Küçük, M., Diebold, J.B., 2012. Uniform basin gr ' wth over the last 500 ka, North Anatolian Fault, Marmara Sea, Turkey. Tectonophysics 518-521, 1-16.

Sueoka, S., Tsutsumi, H., Tagami, T., 2016. New approach to resolve the amount of Quaternary uplift and associated denudation of the mountain ranges in the Japanese islands. Geoscience Frontiers 7, 197-210.

Svitoch, A.A., Selivanov, A.O., Yanina, T.A., 2000. Paleohydrology of the Black Sea Pleistocene basins. Water Resources 27, 594-603. 
Swift, D.J.P., 1968. Coastal erosion and transgressive stratigraphy. Journal of Geology 76, 444456.

Syvitski, J.P.M., Milliman, J.D., 2007. Geology, geography and humans battle for dominance over the delivery of fluvial sediment to the coastal ocean. Journal of Geology 115, 1-19.

Tan, S.H., Tan, S.B., 2010. The correct interpretation of confidence intervals. Proceedings of Singapore Healthcare 19, 276-278.

Thurman, H.V., 1988. Introductory Oceanography. Merrill Publishı_ Company, Columbus, 515 pp.

Tudryn, A., Leroy, S.A.G., Toucanne, S., Gibert-Brunet, E., Tucholka, P., Lavrushin, Y.A., Dufaure, Olivier, D., Serge M., Germain, B., 201c i he Ponto-Caspian basin as a final trap for southeastern Scandinavian ice-shet+ mf Itwater. Quaternary Science Reviews 148, $29-43$.

Türkecan, A., Yurtsever, A., 2002. Geolı sical Map of Turkey, İstanbul Map Sheet. General

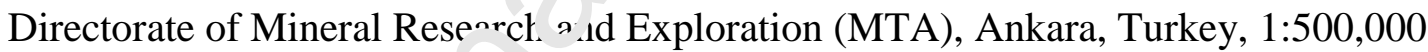
scale.

Turowski, J.M., Rickenmann, 卫 , Dadson, S.J., 2010. The partitioning of the total sediment load of a river into sus ${ }_{1}$ ended load and bedload: a review of empirical data. Sedimentology 57, $1126-1146$.

Valsecchi, V., Sanchez Goñi, M.F., Londeix, L., 2012. Vegetation dynamics in the northeastern Mediterranean region during the past 23000 yr: insights from a new pollen record from the Sea of Marmara. Climate of the Past 8, 1941-1956. 
Vardar, D., Alpar, B., 2017. High-resolution seismic characterization of shallow gas accumulations in the southern shelf of Marmara Sea, Turkey. Acta Geophysica 64, 589609.

Vardar, D., Öztürk, K., Yaltırak, C. Tur, H., 2014. Late Pleistocene-Holocene evolution of the southern Marmara shelf and sub-basins: middle strand of the North Anatolian fault, southern Marmara Sea, Turkey. Marine Geophysical Research 35, 69-85.

Vidal, L., Ménot, G., Joly, C., Bruneton, H., Rostek, F., Çağatay, M. V., Major, C., Bard, E., 2010. Hydrology in the Sea of Marmara during the las ${ }^{+}$? $u^{2}$, years: Implications for timing of Black Sea connections and sapropel depos 'tion. Paleoceanography 25, 1-16.

Warrick, J.A., 2020. Littoral sediment from rivers: patterı , rates and processes of river mouth morphodynamics. Frontiers in Earth Scienc 8 article 355. doi: 10.3389/feart.2020.00355

Wong, H.K., Lüdmann, T., Uluğ, A., Göri“* N', 1995. The Sea of Marmara: a plate boundary sea in an escape tectonic regime. Tec. nnophysics $244,231-250$.

Yaltırak, C., Sakınç, M., Aksu, A.F, H crott, R.N., Galleb, B., Ülgen, U.B., 2002. Global sealevel variations and raist. ' coastal deposits along the southwestern Marmara Sea during the last 224,000 yenrs. : ‘. . urine Geology 190: 283-305.

Yanchilina, A.G., Ryan, 'v.B.F., McManus, J.F., Dimitrov, P., Dimitrov, D., Slavova, K., Filipova-Marinova, M., 2017. Compilation of geophysical, geochronological, and geochemical evidence indicates a rapid Mediterranean-derived submergence of the Black Sea's shelf and subsequent substantial salinification in the early Holocene. Marine Geology 383, 14-34. 
Yanchilina, A.G., Ryan, W.B.F., Kenna, T.C., McManus, J.F., 2019. Meltwater floods into the Black and Caspian seas during Heinrich Stadial 1. Earth-Science Reviews 198, doi.org/10.1016/j.earscirev.2019.102931

Zitter, T.A.C., Grall, C., Henry, P., Özeren, M.S., Çağatay, M.N., Şengör, A.M.C., Gasperini, L, Mercier de Lépinay, B., Géli, L., 2012. Distribution, morphology and triggers of submarine mass wasting in the Sea of Marmara. Marine Geology 329-331, 58-74. 


\section{Figure Captions}

Figure 1. (A) Location of the study area in western Turkey. (B) Map of the Marmara Sea as a gateway linking the Black Sea to the Aegean Sea via the Straits of Bosphorus and Dardanelles. Coastline and rivers are from NOAA National Geophysical Data Center, extracted from http://www.ngdc.noaa.gov/mgg/shorelines/ shorelines.html. Topography and bathymetry compiled using GeoMapApp (Ryan et al., 2009), bathymetry of the Marmara Sea compiled from Rangin et al. (2001). White dasil 1 line (long dashes) represents the catchment area of water courses draining $: \cdots t$, s using the digital topography in Global Mapper. Whitc lines with shorter dashes delimit the portion of this catchment called the Susurluk Drain _ e Basin (Kazancı et al., 2019) which includes tributaries of the Kocasu River. $\mathrm{N}_{\mathrm{i}}$ ' th 't the Kocasu River and the Gönen, Biga and Kemer streams enter Marmara $s$ a f. om the south, and several much smaller streams from the north, including $\mathrm{A}=\mathrm{Ana}, \mathrm{K} 1=\mathrm{K} \mathrm{n}_{1 \mathrm{kl}}, \mathrm{K}=\mathrm{Kula}, \mathrm{Ku}=$ Kurbağalıdere streams. Tekirdağ, Central, Kumburga - Ç 'n „rcık and İmralı are basins and Manyas and Uluabat are Lakes discussed in text. 5乞 $\mathrm{m}$ and $100 \mathrm{~m}$ isobaths are from IOC (1981). Red box is illustrated in Figure 1

Figure 2. (A) Location o: EIE stations (white filled circles with red numbers). Also shown are the drainage areas of the Kocasu River and the Gönen and Biga streams (white dashed lines). Emet, Kocaçay, Nilüfer, Orhaneli and Simav are branches of the Kocasu River. The inset (B) shows an enlargement of the Karacabey gorge and sample locations in that area (red filled circles). The gorge connects the low-lying alluvial plain (including the Manyas and Uluabat Lakes) behind the shore parallel rugged hills, including Karadağ Mountain, and the present-day coastal. Credits for the base maps are given in the Figure 1 caption. 
Figure 3. Geological maps of the Marmara region, simplified and redrawn from the 1:500,000 İzmir and İstanbul Map Sheets of Konak (2002) and Türkecan and Yurtsever (2002), respectively. Because of the complicated nature of the map, the pertinent geology is presented in four panels: (A) ophiolitic mélange and plutonic rocks; (B) metamorphic rocks, $(\mathrm{C})$ volcanic rocks and (D) sedimentary rocks. $\mathrm{b}=$ Biga Stream, $\mathrm{g}=$ Gönen Stream, $\mathrm{k}=$ Kocasu River, $\mathrm{c}=$ coastal erosion along the southeastern Gallipoli Peninsula and northern shoreline of the Marmara Sea. Credits for the base 1. . $p$ are given in the Figure 1 caption.

Figure 4. Map of the study area showing the locations of $t_{1}{ }^{2}$ seismic reflection profiles (white lines) and piston and gravity cores used in this stua, Red, aquamarine, white and yellow filled circles are gravity, piston, Calipso ard 'IV ngstone cores, respectively. Credits for the base map are given in the Figure $1 \mathrm{c} \cdot$ ption.

Figure 5. Graphs showing the pre-dam 1 'ationships between water discharges and suspended sediment loads in the Emet $a^{r d} \mathrm{~K}$ `r açay branches (stations 302 and 314) of the Kocasu River and the Gönen strea`` (station 210). Data are compiled from EIE (1982, 1987, 1993, 2000) sources. The ? $^{\text {nd }}$ o.d $-\mathrm{r}$ quadratic equations are used for the calculation of post-13.8 cal ka sediment bui'rets.

Figure 6. High-resolution Huntec seismic reflection profile showing the internal architecture of the sedimentary successions across the southwestern Marmara Sea and the correlation of seismostratigraphic Unit 1 with core M02-106P. Vertical scale is calculated using $1500 \mathrm{~m}$ $\mathrm{s}^{-1}$ acoustic velocity. Red numbers $=$ navigation fix positions. Location is shown in the inset and Figure 4. 
Figure 7. (A) Depositional domains for the purpose of comparison between the volumes of Unit 1 sediments (latest Quaternary; post-13.8 cal ka) across the Marmara Sea and the sediment contributions of the Kocasu River and the Gönen and Biga streams. (B) Thickness distribution of Unit 1 (in metres, calculated using $1500 \mathrm{~m} \mathrm{~s}^{-1}$ acoustic velocity in seismic reflection profiles) across the Marmara Sea. Thicknesses of Holocene sediments in the Manyas and Uluabat Lakes are from Kazanc1 et al (2004). Also shown are the Kocasu River and the Gönen, Biga, Ana (A), Kınıklı (K1), Kula (K) aıı ${ }^{`}$ Kurbağalıdere (Ku) streams. Note the thick accumulation of Unit 1 in the so entrance to the Strait of Dardanelles, off the mouth or the Kocasu River, as well as in deep water basins. Credits for the base map are given in $:-$ Figure 1 caption.

Figure 8. Lithostratigraphic logs of cores used in i' is t tudy, showing radiocarbon dates (in cal yr $\mathrm{BP}$; see Supplementary Material $2 \mathrm{f} \cdot \mathrm{r}_{\mathrm{N}}{ }^{14} \mathrm{C}$ ages $)$. Gravity cores at the sites of M02103P, M02-104P and M02-106P a monstrate core-top losses of $74 \mathrm{~cm}, 100 \mathrm{~cm}$ and $36 \mathrm{~cm}$ in those piston cores, respectirely 7 .he volcanic ash layer in cores M02-89P, M02-90P, M02-102P and M14-16P ^ the regionally widespread Y2 ash dated at 21,945 cal yr BP. Credits for the locatinn ${ }_{1} \cdots \rho$ are given in the Figure 1 caption. On the map, a trailing $\mathrm{P}$ is omitted from every ?iston core name to reduce clutter.

Figure 9. Summary core logs for Calypso cores raised from deep basins of the Marmara Sea, extracted from Beck et al. (2007, 2015), Çağatay et al. (2009), Vidal et al. (2010), Eriş et al. (2011, 2012), Campos (2014) and Aloisi et al. (2015). Unit 1 is the marine section, shown either as a green fill or grey (sapropel M1). Credits for the location map are given in the Figure 1 caption. 
Figure 10. High-resolution Huntec seismic reflection showing the internal architecture of the sedimentary successions across the Dardanelles channel at the northeastern entrance to the Strait of Dardanelles. The $d$ reflector ( $d$ for Dardanelles) is interpreted as an unconformity, explained in the text. Vertical scale in metres is calculated using $1500 \mathrm{~m} \mathrm{~s}^{-1}$ acoustic velocity; VE (vertical exaggeration) $\sim 23 \times$. Red numbers at base = navigation fix positions . Location is shown in the inset where red- and aqua-filled circles are gravity and piston cores, respectively.

Figure 11. Interpreted Huntec DTS profile across the 11.1-1ศ.2 cai ka Holocene outflow delta at the southern exit of the Strait of Bosphorus, modifiea 'rom Aksu et al. (2016). Subtle upand-down wobbles along the seabed result from tow ish flight variations created by strong currents in the area. Ages of reflectors are: $\beta: 1$ J.2 cal ka; $\beta 2,11.8 \mathrm{cal} \mathrm{ka} ; \beta 3,12.0 \mathrm{cal} \mathrm{ka}$; $\beta 4,16.2$ cal ka. Everything above $\beta 3$ ' $^{\prime}$ songs to Unit 1 of this study.

Figure 12. Log-log plot of average eleme.. ${ }^{+}$al abundances in the modern versus abundances in shelf cores M02-103P and N $\mathrm{v}_{2}$ livoP (blue dots) and deep basinal cores (red dots). Blue dots are alway on top, sc in , laces partially obscure other data points. The order of elements, left to rig' $\iota$, in same as the ranking in Table 5. Only the anomalies are labelled, but the ide tity of other pairs can be determined using the tabulated values. Blue and red dots for each element are aligned vertically, and their degree of separation is a qualitative indication of the difference in shelf and deep basin means. 


\section{Table Captions}

Table 1. Characteristics of Unit 1 (uppermost Pleistocene to Holocene mud drape), from literature sources.

Table 2. Volumes of porous, water-saturated Unit 1 mud in various parts of the Marmara Sea. Thicknesses were determined from seismic profiles assuming an acoustic velocity of $1500 \mathrm{~m} \mathrm{~s}^{-1}$. Values for domain 5 consider the lakes only and not adjacent portions of the inland depression.

Table 3. Contributions of river and stream detritus to the Marma ${ }^{2}$ dsin as environmental conditions changed since 13.8 cal ka. Column 4 giv s annual suspended loads from gauging station daily records and equations in Fig $\_5$. The values in column 5 are the result of reducing daily water discharges $t^{r}, 7 c$, of modern measurements to acknowledge a drier climate durin th Younger Dryas. Columns 6-9 take account of constraints noted in Section 4.2.1 'e.g., 20\% increment at certain times for bedload). Column 10 sums columns 69 . Frlumn 11 converts the values in column 10 to an equivalent volume of sec̈ ment with $60 \%$ porosity, a grain density of $2.65 \mathrm{t} \mathrm{m}^{-3}$, and a $10 \%$ increment for the $: i$ sgenic carbonate added to river input in the marine setting. To convert, divide $b, 2.65$, then by $1.0-0.60=0.40$ and finally multiply by 1.1 .

Table 4. Input values (columns 3-7) for BQART determinations (columns 8-11) of river suspended-load contributions. Column 4 presents averages over 30-60 years (gauging stations), reduced in Younger Dryas to account for less rainfall. Column 6 is from Google Earth $^{\mathrm{TM}}$ (Ruler>Path $>$ Profile). Column 7 is from Valsecchi et al. (2012) with an interpolated value of temperature for $11.7-7.0 \mathrm{cal}$ ka. Columns $8-10$ are calculated using equation 7a of Syvitski and Milliman (2007). The values in column 11 are based on totals 
for each branch incremented by $20 \%$ for bedload (only before $4.1 \mathrm{cal}$ ka for Emet and Kocaçay branches due to Manyas and Uluabat trapping afterward), then reduced to $40 \%$ of that amount (following the Kukal, 1971, suggestion that $60 \%$ remains on the floodplain and in the delta during highstands), then inflated to an assumed porosity of $60 \%$ with an additional $10 \%$ increment for biogenic carbonate. These are estimates of the volumes available to Unit 1 since $13.8 \mathrm{cal} \mathrm{ka}$. The TOTAL includes $\pm 7 \%$ expected bias (Syvitski and Milliman, 2007).

Table 5. Mean abundances of elements from LA-ICPMS mea $\cdots r_{4} \cdots$ nts, ranked in order of decreasing abundance in the Kocasu Delta sample s. ${ }^{+}$. Column 1 averages samples M171 to M17-7; column 3 averages samples from she. ${ }^{-}$. ores M02-103P and M02-106P; column 4 averages samples from basinal a`es M02-88P, M02-89P, M02-90P, M02102P. Column 5 indicates if 95\% c $n f$ dence intervals (C.I.) overlap for Kocasu and all marine data (shelves and basins), olumn 6 indicates if 95\% confidence intervals overlap for delta and shelf samples $n \eta y$, slumn 7 indicates if delta and shelf samples have indistinguishable means asec on a two-tailed student t-test.

Table 6. Inferred evolution nt ? Ardanelles valley and channel after the Last Glacial Maximum. SW flow is towaı. the Aegean Sea; NE flow is toward the Marmara Sea. 
Table 1.

\begin{tabular}{|c|c|c|}
\hline Feature or parameter & Value or description & Sources \\
\hline Texture & $\begin{array}{l}\text { Mixtures of generally }<10- \\
15 \% \text { sand, clay }>30 \% \text { (rarely } \\
\text { less near deltas and } \\
\text { shorelines), silt }>10 \% \text { and } \\
<30 \% \text { in deep basins. Silt- } \\
\text { fine sandy laminae } \\
\text { intercalated in deep basins. }\end{array}$ & $\begin{array}{l}\text { Ergin and Bodur (1999), Beck } \\
\text { et al. (2007), Hiscott et al. } \\
\text { (2017) }\end{array}$ \\
\hline Facies & 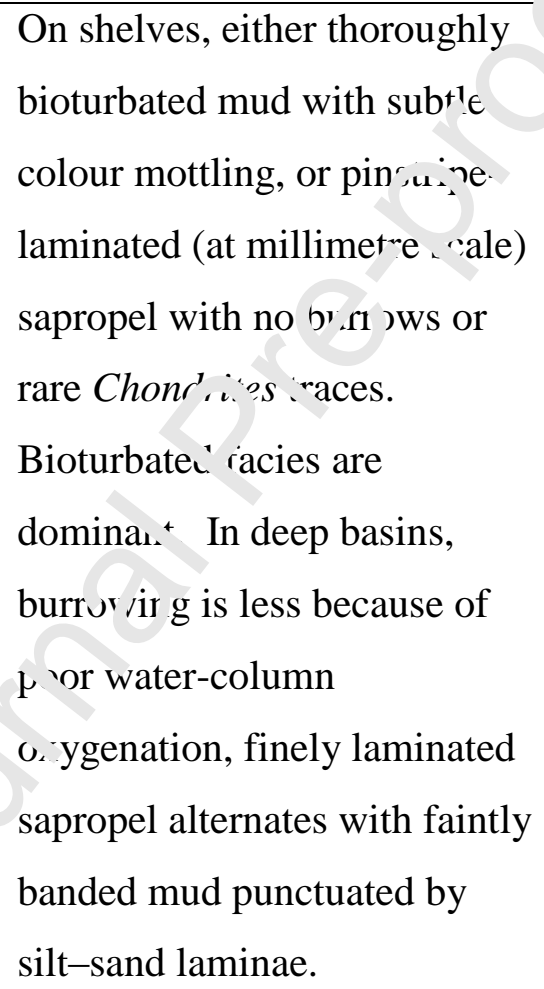 & $\begin{array}{l}\text { C: ğatay et al. (2000), Aksu et } \\
\text { al. (2002, 2016), Beck et al. } \\
(2007), \text { Eriş et al. (2012) }\end{array}$ \\
\hline Sand to coarse silt fraction & $\begin{array}{l}\text { Predominantly biogenic } \\
\text { carbonate grains } \\
\text { (foraminifera, juvenile or } \\
\text { fragmented molluscs) with } \\
\text { increased siliciclastic detritus } \\
\text { in very fine sand fraction, } \\
\text { including many mafic } \\
\text { minerals and metamorphic }\end{array}$ & $\begin{array}{l}\text { Aksu et al. (2002), Beck et al. } \\
\text { (2007), Hiscott et al. (2017) }\end{array}$ \\
\hline
\end{tabular}




\begin{tabular}{|l|l|l|}
\hline & grains. In deep basins, silt is & \\
& rich in fresh plagioclase, & \\
amphibole and pyroxene, & \\
brown mica, opaques & minerals and detrital (rather \\
than biogenic carbonate). & \\
\hline Clay minerals & $\begin{array}{l}\sim 50 \% \text { smectite, } \sim 25-30 \% \\
\text { illite, 10-20\% kaolinite, } \\
<10 \% \text { chlorite }\end{array}$ & $\begin{array}{l}\text { Bayhan et al. (2001), Kazanc1 } \\
\text { et al. (2004), Ehrmann et al. } \\
(\angle \uparrow) 7)\end{array}$ \\
\hline
\end{tabular}

Table 1 continued.

\begin{tabular}{|c|c|c|}
\hline Feature or parameter & Value or description & Sources \\
\hline Organic carbon & $\begin{array}{l}\text { TOC mostly } 0.5-3.0 \% \text {, } \\
\text { highest in deep b in: and } \\
\text { laminated sal rop.ls. }\end{array}$ & $\begin{array}{l}\text { Çağatay et al. (2000), } \\
\text { Abrajano et al. (2002), Ergin } \\
\text { et al. (2007) }\end{array}$ \\
\hline Carbonate content & $\begin{array}{l}7-20 \% \text { but } \text {, nically } \sim 10-15 \% \\
\text { as } \mathrm{CarC}_{3}\end{array}$ & $\begin{array}{l}\text { Çăgatay et al. (2000), Ergin et } \\
\text { al. (2007), Beck et al. (2007) }\end{array}$ \\
\hline Macrofossils & $\begin{array}{l}\text { Mnllu s, : Corbula gibba, } \\
\text { M, tilus galloprovincialis, } \\
\text { 7ımoclia ovata, Paphia } \\
\text { discrepans, Donax trunculus, } \\
\text { Cardium (or Cerastoderma) } \\
\text { edule, Parvicardium exiguum, } \\
\text { Bittium reticureticulatum, } \\
\text { Chlamys varia, Spisula } \\
\text { subtruncata, Abra alba, } \\
\text { Turritella communis, Myrtea } \\
\text { spinifera; species of Vermetus, } \\
\text { Patella, Cyrcomphalus, } \\
\text { Hydrobia, Dentalium, Nucula. }\end{array}$ & $\begin{array}{l}\text { Çağatay et al. (2000), Aksu et } \\
\text { al. (2016), Büyükmeriç (2016) }\end{array}$ \\
\hline
\end{tabular}




\begin{tabular}{|c|c|c|}
\hline & $\begin{array}{l}\text { Rare serpulid tubes, } \\
\text { echinoderm plates, crustacean } \\
\text { claws. }\end{array}$ & \\
\hline Microfossil groups & $\begin{array}{l}\text { Benthic and planktonic } \\
\text { foraminifera, nannofossils, } \\
\text { dinoflagellate cysts, pollen } \\
\text { and spores, diatoms }\end{array}$ & $\begin{array}{l}\text { Çağatay et al. (2000), Aksu et } \\
\text { al. (2002), Kaminski et al. } \\
\text { (2002), Mudie et al. (2002a, } \\
\text { 2002b), McHugh et al. (2008), } \\
\text { Londeix et al. (2009), } \\
\text { va'secchi et al. (2012) }\end{array}$ \\
\hline Colour & 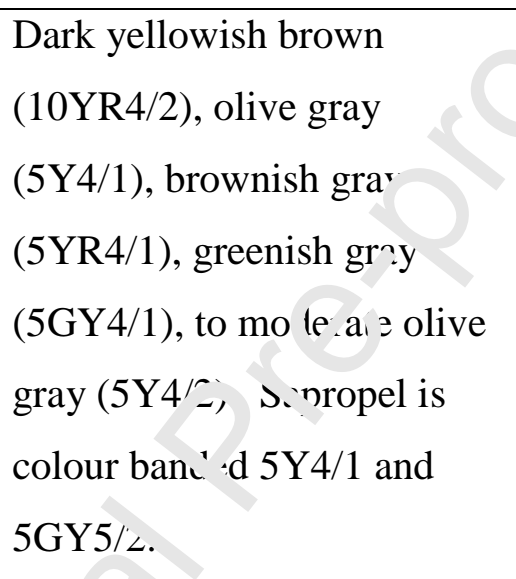 & $\bar{A}^{1}$ su et al. (2002) \\
\hline
\end{tabular}

Table 2.

\begin{tabular}{|l|l|l|}
\hline Do & T & V \\
m & h & o \\
n & i & I \\
& c & u \\
& k & m \\
& n & e \\
& e & w \\
& S & i \\
& r & h \\
& a & $\mathbf{p}$ \\
\hline
\end{tabular}




\section{Journal Pre-proof}

\begin{tabular}{|c|c|c|}
\hline & $\begin{array}{l}\text { g } \\
\text { e } \\
\text { ( } \\
\text { m } \\
\text { ) }\end{array}$ & $\begin{array}{l}\mathbf{o} \\
\mathbf{r} \\
\mathbf{e} \\
\mathbf{w} \\
\mathbf{a} \\
\mathbf{t} \\
\mathbf{e} \\
\mathbf{r} \\
( \\
\mathbf{k} \\
\mathbf{m} \\
\mathbf{3} \\
\text { ) }\end{array}$ \\
\hline $\begin{array}{l}\text { (1) } \\
\text { So } \\
\text { uth } \\
\text { ern } \\
\text { sh } \\
\text { elf }\end{array}$ & $\begin{array}{l}0 \\
- \\
2 \\
5\end{array}$ & . \\
\hline $\begin{array}{l}\text { (2) } \\
\text { So } \\
\text { uth } \\
\text { we } \\
\text { ste } \\
\text { rn } \\
\text { sh } \\
\text { elf }\end{array}$ & $\begin{array}{l}0 \\
- \\
2 \\
5\end{array}$ & $\begin{array}{l}4 \\
. \\
5\end{array}$ \\
\hline $\begin{array}{l}\text { (3) } \\
\text { No } \\
\text { rth } \\
\text { ern }\end{array}$ & $\begin{array}{l}0 \\
- \\
3 \\
0\end{array}$ & 4 \\
\hline
\end{tabular}




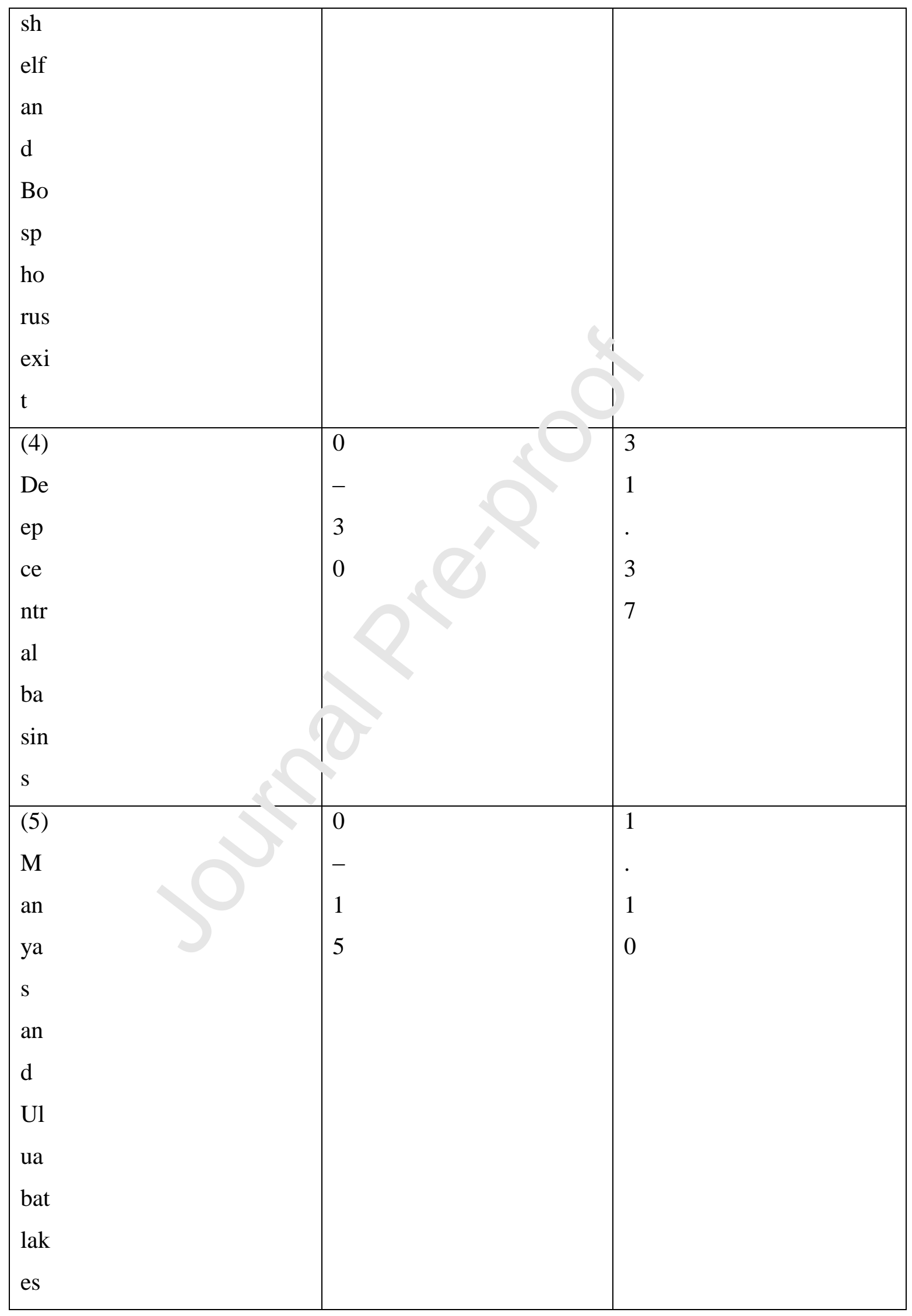




\begin{tabular}{|l|l|l|}
\hline onl & & \\
\hline To & & 4 \\
tal & 5 \\
(d & & 6 \\
om & & 0 \\
ain & & 1 \\
s & & \\
1, & & \\
\hline 2, & & \\
\hline
\end{tabular}


Table 3.

\begin{tabular}{|c|c|c|c|c|c|c|c|c|c|c|}
\hline 1 & 2 & 3 & 4 & 5 & 6 & 7 & 8 & 9 & 10 & 11 \\
\hline $\begin{array}{l}\text { Syste } \\
\text { m }\end{array}$ & $\begin{array}{l}\text { Bran } \\
\text { ch }\end{array}$ & $\begin{array}{l}\text { yrs } \\
\text { of } \\
\text { dai } \\
\text { ly } \\
\text { dat } \\
\text { a }\end{array}$ & $\begin{array}{l}{\mathrm{t} \mathrm{yr}^{-1}} \\
\text { Holoce } \\
\text { ne }\end{array}$ & $\begin{array}{l}\mathbf{t} \mathbf{y r}^{-1} \\
\text { YD }\end{array}$ & $\begin{array}{l}13 . \\
8- \\
11 . \\
7 \\
\text { Gt }\end{array}$ & $\begin{array}{l}11.7 \\
-7.0 \\
\text { Gt }\end{array}$ & $\begin{array}{l}7.0 \\
- \\
4.1 \\
\text { Gt }\end{array}$ & $\begin{array}{l}4.1- \\
0 \\
\text { Gt }\end{array}$ & $\begin{array}{l}\text { Tota } \\
\text { I } \\
\text { Gt }\end{array}$ & $\begin{array}{l}\text { Total } \\
\text { at } \\
60 \% \\
\text { poros } \\
\text { ity } \\
\left(\mathrm{km}^{3}\right)\end{array}$ \\
\hline \multirow[t]{4}{*}{$\begin{array}{l}\text { Koca } \\
\text { su }\end{array}$} & $\begin{array}{l}\text { Kocaç } \\
\text { ay }\end{array}$ & 55 & $\begin{array}{l}48745 \\
6\end{array}$ & $\begin{array}{l}2273 \\
14\end{array}$ & $\begin{array}{l}0.5 \\
73\end{array}$ & $\begin{array}{l}2.74 \\
9\end{array}$ & $\begin{array}{l}0 \% \\
i ?\end{array}$ & $\begin{array}{l}0.79 \\
9\end{array}$ & $\begin{array}{l}4.80 \\
0\end{array}$ & 4.98 \\
\hline & $\begin{array}{l}\text { Emet } \\
+ \\
\text { Orhan } \\
\text { eli }\end{array}$ & 61 & $\begin{array}{l}19246 \\
83\end{array}$ & $\begin{array}{l}8868 \\
18\end{array}$ & $\begin{array}{l}2.2 \\
35\end{array}$ & $\begin{array}{l}10.8 \\
1,\end{array}$ & 2.6 & $\begin{array}{l}3.15 \\
6\end{array}$ & $\begin{array}{l}18.9 \\
26\end{array}$ & 19.64 \\
\hline & Simav & 59 & $\begin{array}{l}15975 \\
74\end{array}$ & $\begin{array}{l}7342 \\
00\end{array}$ & $\begin{array}{l}1 . \bar{c} \\
50\end{array}$ & $\begin{array}{l}9.01 \\
0\end{array}$ & $\begin{array}{l}2.2 \\
24\end{array}$ & $\begin{array}{l}3.14 \\
4\end{array}$ & $\begin{array}{l}16.2 \\
28\end{array}$ & 16.84 \\
\hline & $\begin{array}{l}\text { Nilüfe } \\
\text { r }\end{array}$ & 49 & $\begin{array}{l}12331 \\
1\end{array}$ & 675 & $\begin{array}{l}0.1 \\
58\end{array}$ & $\begin{array}{l}0.69 \\
5\end{array}$ & $\begin{array}{l}0.1 \\
72\end{array}$ & $\begin{array}{l}0.24 \\
3\end{array}$ & $\begin{array}{l}1.26 \\
7\end{array}$ & 1.32 \\
\hline \multirow[t]{2}{*}{$\begin{array}{l}\text { Göne } \\
\text { n }\end{array}$} & $\begin{array}{l}\text { Göne } \\
\mathrm{n}\end{array}$ & 37 & $\overline{73727}$ & $\begin{array}{l}3621 \\
5\end{array}$ & $\begin{array}{l}0.0 \\
91\end{array}$ & $\begin{array}{l}0.41 \\
6\end{array}$ & $\begin{array}{l}0.1 \\
03\end{array}$ & $\begin{array}{l}0.14 \\
5\end{array}$ & $\begin{array}{l}0.75 \\
5\end{array}$ & 0.78 \\
\hline & Keçi & 29 & $\angle \therefore 4 \overline{0}$ & 1563 & $\begin{array}{l}0.0 \\
04\end{array}$ & $\begin{array}{l}0.01 \\
4\end{array}$ & $\begin{array}{l}0.0 \\
03\end{array}$ & $\begin{array}{l}0.00 \\
5\end{array}$ & $\begin{array}{l}0.02 \\
6\end{array}$ & 0.03 \\
\hline Biga & Biga & 46 & 62426 & $\begin{array}{l}3086 \\
2\end{array}$ & $\begin{array}{l}0.0 \\
78\end{array}$ & $\begin{array}{l}0.35 \\
2\end{array}$ & $\begin{array}{l}0.0 \\
87\end{array}$ & $\begin{array}{l}0.12 \\
3\end{array}$ & $\begin{array}{l}\underline{0.64} \\
\underline{0}\end{array}$ & $\underline{0.66}$ \\
\hline $\begin{array}{l}\text { Gran } \\
\text { d } \\
\text { total }\end{array}$ & & & & & & & & $\begin{array}{l}42.6 \\
42\end{array}$ & $\begin{array}{l}44.2 \\
5\end{array}$ & \\
\hline
\end{tabular}


Table 4.

\begin{tabular}{|c|c|c|c|c|c|c|c|c|c|c|}
\hline 1 & 2 & 3 & 4 & 5 & 6 & 7 & 8 & 9 & $\begin{array}{l}1 \\
0\end{array}$ & $\begin{array}{l}1 \\
1\end{array}$ \\
\hline $\begin{array}{l}\text { B } \\
\mathbf{r} \\
\mathbf{a} \\
\mathbf{n} \\
\mathbf{c} \\
\mathbf{h}\end{array}$ & $\begin{array}{l}\mathbf{R} \\
\mathbf{a} \\
\mathbf{n} \\
\mathbf{g} \\
\mathbf{e}\end{array}$ & B & $\mathbf{Q}$ & $\mathbf{A}$ & $\mathbf{R}$ & $\mathbf{T}$ & $\begin{array}{l}\mathbf{Q} \\
\mathbf{S}\end{array}$ & $\begin{array}{l}\mathbf{D} \\
\mathbf{u} \\
\mathbf{r} \\
\mathbf{a} \\
\mathbf{t} \\
\mathbf{i} \\
\mathbf{o} \\
\mathbf{n}\end{array}$ & $\begin{array}{l}\mathbf{T} \\
\mathbf{o} \\
\mathbf{t} \\
\mathbf{a} \\
\mathbf{l}\end{array}$ & $\begin{array}{l}\mathbf{T} \\
\mathbf{0} \\
\mathbf{t} \\
\mathbf{a} \\
\mathbf{l} \\
\mathbf{a} \\
\mathbf{t} \\
\mathbf{6} \\
\mathbf{0} \\
\%\end{array}$ \\
\hline & $\begin{array}{l}\mathbf{c} \\
\mathbf{a} \\
\mathbf{l} \\
\mathbf{k} \\
\mathbf{a}\end{array}$ & & $\begin{array}{l}\mathbf{k} \\
\mathbf{m}\end{array}$ & $\begin{array}{l}\mathbf{k} \\
\mathbf{m}\end{array}$ & $\begin{array}{l}\mathbf{k} \\
\mathbf{m}\end{array}$ & $\begin{array}{l}\overline{\mathbf{o}} \\
\mathrm{C}\end{array}$ & $\begin{array}{l}\mathbf{M} \\
\mathbf{t} \\
\mathbf{y} \\
\mathbf{r} \\
- \\
\mathbf{1}\end{array}$ & $\begin{array}{l}\mathbf{y} \\
\mathbf{r}\end{array}$ & $\begin{array}{l}\mathbf{G} \\
\mathbf{t}\end{array}$ & $\begin{array}{l}\mathbf{p} \\
\mathbf{o} \\
\mathbf{r} \\
\mathbf{o} \\
\mathbf{S} \\
\mathbf{i} \\
\mathbf{t} \\
\mathbf{y}\end{array}$ \\
\hline $\begin{array}{l}\mathbf{E} \\
\mathbf{m} \\
\mathbf{e} \\
\mathbf{t} \\
\mathbf{\&} \\
\mathbf{O} \\
\mathbf{r} \\
\mathbf{h} \\
\mathbf{a} \\
\mathbf{n} \\
\mathbf{e} \\
\mathbf{l} \\
\mathbf{i}\end{array}$ & $\begin{array}{l}1 \\
3 \\
0 \\
8 \\
- \\
1 \\
1 \\
7\end{array}$ & $\begin{array}{l}0 \\
0\end{array}$ & $\begin{array}{l}1 \\
. \\
1 \\
5 \\
9\end{array}$ & $\begin{array}{l}9 \\
6 \\
2 \\
9\end{array}$ & $\begin{array}{l}1 \\
. \\
1 \\
2 \\
5\end{array}$ & $\begin{array}{l}1 \\
0 \\
0 \\
0\end{array}$ & $\begin{array}{l}0 \\
6 \\
6 \\
9 \\
3\end{array}$ & $\begin{array}{l}2 \\
1 \\
0 \\
0\end{array}$ & $\begin{array}{l}1 \\
. \\
4 \\
5 \\
6\end{array}$ & \\
\hline
\end{tabular}




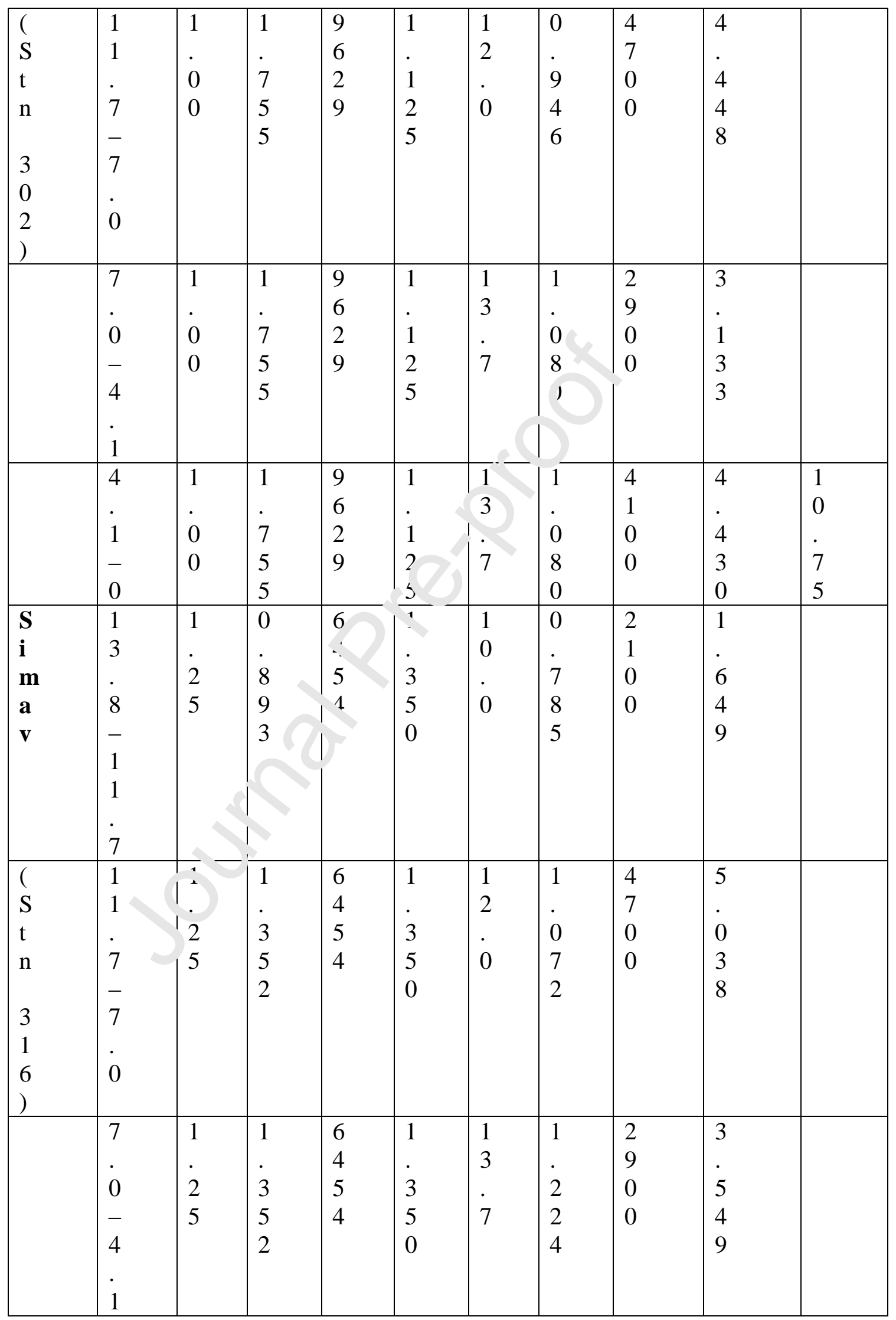




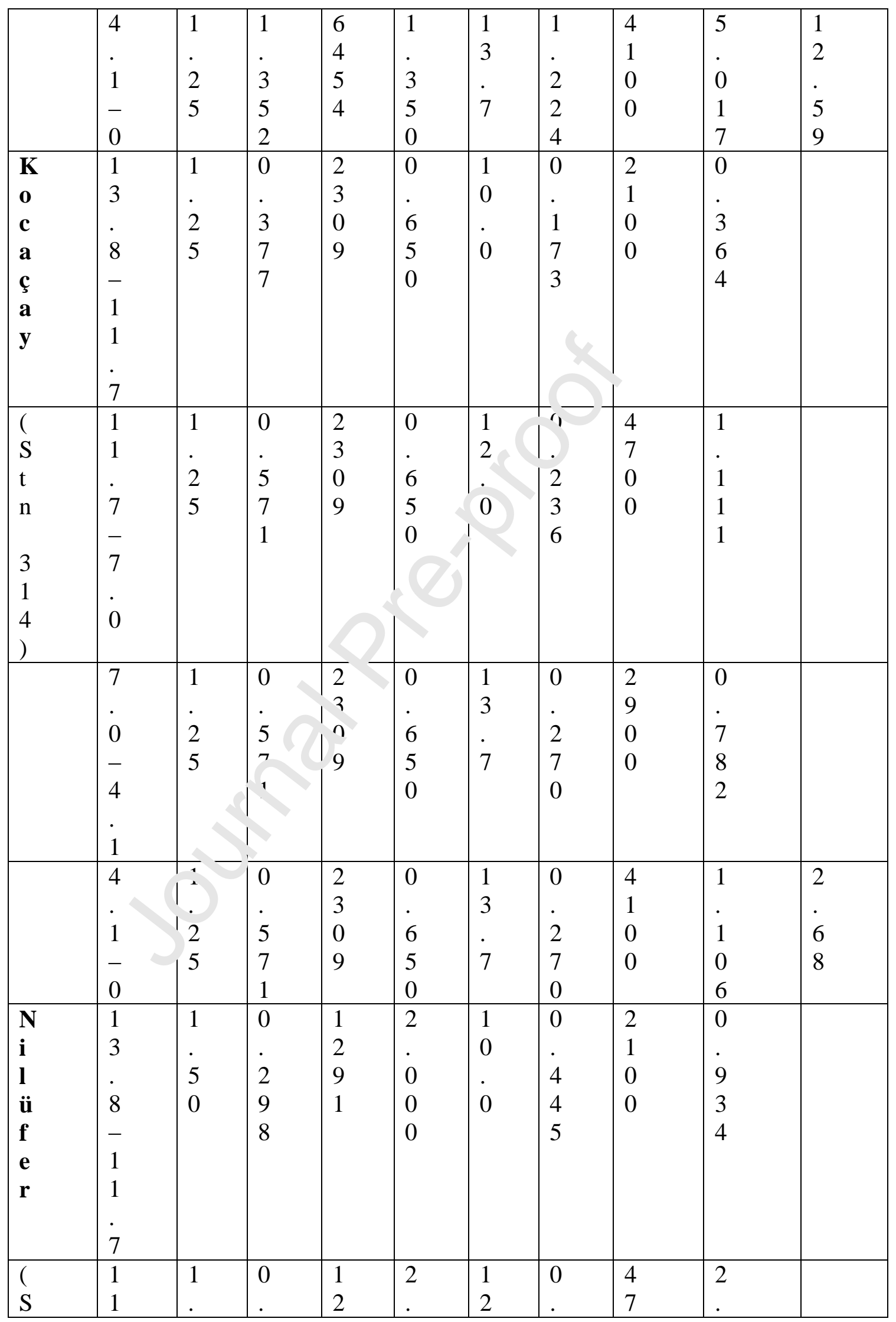




\begin{tabular}{|c|c|c|c|c|c|c|c|c|c|c|}
\hline $\begin{array}{l}3 \\
2 \\
1 \\
)\end{array}$ & $\begin{array}{l}\overline{7} \\
- \\
7 \\
\dot{0}\end{array}$ & $\begin{array}{l}5 \\
0\end{array}$ & $\begin{array}{l}4 \\
5 \\
2\end{array}$ & $\begin{array}{l}9 \\
1\end{array}$ & $\begin{array}{l}0 \\
0 \\
0\end{array}$ & $\dot{0}$ & $\begin{array}{l}6 \\
0 \\
7\end{array}$ & $\begin{array}{l}0 \\
0\end{array}$ & $\begin{array}{l}8 \\
5 \\
2\end{array}$ & \\
\hline & $\begin{array}{l}7 \\
. \\
0 \\
- \\
4 \\
1\end{array}$ & $\begin{array}{l}1 \\
5 \\
5 \\
0\end{array}$ & $\begin{array}{l}0 \\
. \\
4 \\
5 \\
2\end{array}$ & $\begin{array}{l}1 \\
2 \\
9 \\
1\end{array}$ & $\begin{array}{l}2 \\
. \\
0 \\
0 \\
0\end{array}$ & $\begin{array}{l}1 \\
3 \\
7\end{array}$ & $\begin{array}{l}0 \\
6 \\
6 \\
9 \\
3\end{array}$ & $\begin{array}{l}2 \\
9 \\
0 \\
0\end{array}$ & $\begin{array}{l}2 \\
. \\
0 \\
0 \\
9\end{array}$ & \\
\hline & $\begin{array}{l}4 \\
. \\
1 \\
- \\
0\end{array}$ & $\begin{array}{l}1 \\
5 \\
5 \\
0\end{array}$ & $\begin{array}{l}0 \\
4 \\
4 \\
5 \\
2\end{array}$ & $\begin{array}{l}1 \\
2 \\
9 \\
1\end{array}$ & $\begin{array}{l}2 \\
. \\
0 \\
0 \\
0\end{array}$ & \begin{tabular}{|l}
1 \\
3 \\
7
\end{tabular} & $\begin{array}{l}1 \\
. \\
6 \\
9 \\
3\end{array}$ & $\begin{array}{l}4 \\
1 \\
0 \\
0\end{array}$ & $\begin{array}{l}2 \\
. \\
8 \\
4 \\
0\end{array}$ & $\begin{array}{l}7 \\
. \\
1 \\
3\end{array}$ \\
\hline $\begin{array}{l}\text { G } \\
\ddot{o} \\
\mathbf{n} \\
\text { e } \\
\text { n }\end{array}$ & $\begin{array}{l}1 \\
3 \\
5 \\
8 \\
1 \\
1\end{array}$ & $\begin{array}{l}1 \\
2 \\
5\end{array}$ & $\begin{array}{l}0 \\
4 \\
1 \\
6\end{array}$ & $\begin{array}{l}1 \\
6 \\
7 \\
i\end{array}$ & $\begin{array}{l}\rho \\
0 \\
0 \\
0 \\
0\end{array}$ & $\begin{array}{l}1 \\
0 \\
0 \\
0\end{array}$ & $\begin{array}{l}0 \\
\dot{1} \\
8 \\
7\end{array}$ & $\begin{array}{l}2 \\
1 \\
0 \\
0\end{array}$ & $\begin{array}{l}0 \\
5 \\
3 \\
9 \\
2\end{array}$ & \\
\hline $\begin{array}{l}( \\
\mathrm{S} \\
\mathrm{t} \\
\mathrm{n} \\
\\
2 \\
1 \\
0\end{array}$ & $\begin{array}{l}1 \\
1 \\
5 \\
7 \\
- \\
7 \\
0\end{array}$ & $\begin{array}{l}1 \\
2 \\
5\end{array}$ & $\begin{array}{l}0 \\
6 \\
6 \\
1\end{array}$ & $\begin{array}{l}1 \\
6 \\
7 \\
0\end{array}$ & $\begin{array}{l}0 \\
. \\
8 \\
0 \\
0\end{array}$ & $\begin{array}{l}1 \\
2 \\
0 \\
0\end{array}$ & $\begin{array}{l}0 \\
2 \\
2 \\
5 \\
5\end{array}$ & $\begin{array}{l}4 \\
7 \\
0 \\
0\end{array}$ & $\begin{array}{l}1 \\
. \\
1 \\
9 \\
9\end{array}$ & \\
\hline & $\dot{0}$ & 2 & $\begin{array}{l}0 \\
6 \\
6\end{array}$ & $\begin{array}{l}1 \\
6 \\
7\end{array}$ & $\begin{array}{l}0 \\
. \\
8\end{array}$ & $\begin{array}{l}1 \\
3 \\
\text {. }\end{array}$ & $\begin{array}{l}0 \\
2 \\
2\end{array}$ & $\begin{array}{l}2 \\
9 \\
0\end{array}$ & $\begin{array}{l}0 \\
8 \\
8\end{array}$ & \\
\hline
\end{tabular}




\begin{tabular}{|c|c|c|c|c|c|c|c|c|c|c|}
\hline & $\begin{array}{l}- \\
4 \\
1\end{array}$ & 5 & $\begin{array}{l}3 \\
1\end{array}$ & 0 & $\begin{array}{l}0 \\
0\end{array}$ & 7 & $\begin{array}{l}9 \\
1\end{array}$ & 0 & $\begin{array}{l}4 \\
5\end{array}$ & \\
\hline & $\begin{array}{c}\dot{1} \\
- \\
0\end{array}$ & $\begin{array}{l}2 \\
5\end{array}$ & $\begin{array}{l}6 \\
3 \\
1\end{array}$ & $\begin{array}{l}1 \\
6 \\
7 \\
0\end{array}$ & $\begin{array}{l}8 \\
0 \\
0\end{array}$ & $\begin{array}{l}1 \\
3 \\
7\end{array}$ & $\begin{array}{l}2 \\
9 \\
1\end{array}$ & $\begin{array}{l}4 \\
1 \\
0 \\
0\end{array}$ & $\begin{array}{l}1 \\
. \\
1 \\
9 \\
4\end{array}$ & $\begin{array}{l}0 \\
0\end{array}$ \\
\hline $\begin{array}{l}\text { B } \\
\mathbf{i} \\
\mathbf{g} \\
\mathbf{a}\end{array}$ & $\begin{array}{l}1 \\
3 \\
8 \\
8 \\
- \\
1 \\
1 \\
7\end{array}$ & $\begin{array}{l}2 \\
5\end{array}$ & $\begin{array}{l}3 \\
3 \\
3\end{array}$ & $\begin{array}{l}2 \\
0 \\
9 \\
6\end{array}$ & $\begin{array}{l}5 \\
5 \\
0\end{array}$ & $\begin{array}{l}1 \\
0 \\
0 \\
0\end{array}$ & $\begin{array}{l}1 \\
3 \\
+\end{array}$ & $\begin{array}{l}2 \\
1 \\
0 \\
0\end{array}$ & $\begin{array}{l}0 \\
2 \\
8 \\
2\end{array}$ & \\
\hline $\begin{array}{l}( \\
\mathrm{S} \\
\mathrm{t} \\
\mathrm{n}\end{array}$ & $\begin{array}{l}1 \\
1 \\
. \\
7 \\
- \\
7 \\
0\end{array}$ & $\begin{array}{l}2 \\
5\end{array}$ & $\begin{array}{l}5 \\
0 \\
5\end{array}$ & $\begin{array}{l}2 \\
0 \\
9\end{array}$ & $\begin{array}{l}5 \\
5 \\
0\end{array}$ & $\begin{array}{l}2 \\
2 \\
0\end{array}$ & $\begin{array}{l}1 \\
8 \\
3\end{array}$ & $\begin{array}{l}4 \\
7 \\
0 \\
0\end{array}$ & $\begin{array}{l}0 \\
. \\
8 \\
6 \\
2\end{array}$ & \\
\hline & $\begin{array}{l}7 \\
0 \\
0 \\
4 \\
1\end{array}$ & 2 & $\begin{array}{l}5 \\
0 \\
5\end{array}$ & $\begin{array}{l}2 \\
0 \\
9 \\
6\end{array}$ & $\begin{array}{l}5 \\
5 \\
0\end{array}$ & $\begin{array}{l}1 \\
3 \\
7\end{array}$ & $\begin{array}{l}2 \\
0 \\
9\end{array}$ & $\begin{array}{l}2 \\
9 \\
0 \\
0\end{array}$ & $\begin{array}{l}0 \\
. \\
6 \\
0 \\
7\end{array}$ & \\
\hline & $\begin{array}{l}4 \\
1 \\
1 \\
0\end{array}$ & $\begin{array}{l}2 \\
5\end{array}$ & $\begin{array}{l}5 \\
5 \\
0 \\
5\end{array}$ & $\begin{array}{l}2 \\
0 \\
9 \\
6\end{array}$ & $\begin{array}{l}5 \\
5 \\
0\end{array}$ & $\begin{array}{l}1 \\
3 \\
7\end{array}$ & $\begin{array}{l}\dot{2} \\
0 \\
9\end{array}$ & $\begin{array}{l}4 \\
1 \\
0 \\
0\end{array}$ & $\begin{array}{l}\underline{0} \\
\overline{\overline{8}} \\
\frac{8}{5} \\
\underline{8} \\
\end{array}$ & $\begin{array}{l}\overline{\overline{1}} \\
\underline{5}\end{array}$ \\
\hline & & & & & & & & & $\begin{array}{l}\mathrm{T} \\
\mathrm{O} \\
0 \\
0 \\
5 \\
4 \\
\mathrm{~A}\end{array}$ & $\begin{array}{l}3 \\
8\end{array}$ \\
\hline
\end{tabular}




\begin{tabular}{|l|l|l|l|l|l|l|l|l|l|}
\hline & & & & & & & & L & 2 \\
& & & & & & & & & \\
\hline
\end{tabular}


Table 5.

\begin{tabular}{|c|c|c|c|c|c|c|}
\hline 1 & 2 & 3 & 4 & 5 & 6 & 7 \\
\hline & $\mathbf{a}$ & $\begin{array}{l}\mathbf{0} \\
\mathbf{3} \\
/ \\
\mathbf{1}\end{array}$ & $\begin{array}{l}\text { b } \\
\mathbf{a} \\
\mathrm{s} \\
\mathbf{i} \\
\mathrm{n} \\
\mathrm{s}\end{array}$ & $\begin{array}{l}\mathbf{0} \\
\mathbf{v} \\
\text { e } \\
\text { r } \\
\text { l } \\
\text { a } \\
\text { p }\end{array}$ & $\begin{array}{l}\text { o } \\
\text { v } \\
\text { e } \\
\text { r } \\
\text { l } \\
\text { a } \\
\text { p }\end{array}$ & $\mathbf{t}$ \\
\hline & $\begin{array}{l}\mathbf{g} \\
-\end{array}$ & $\begin{array}{l}\mathbf{g} \\
-\end{array}$ & $\begin{array}{l}\mathbf{g} \\
- \\
\end{array}$ & $\begin{array}{l}9 \\
5 \\
y\end{array}$ & $\begin{array}{l}9 \\
5 \\
\%\end{array}$ & 0 \\
\hline $\begin{array}{l}\mathbf{m} \\
\mathbf{e} \\
\mathbf{n}\end{array}$ & 7 & $\begin{array}{l}1 \\
5\end{array}$ & $\begin{array}{l}\mathrm{n} \\
= \\
2 \\
3\end{array}$ & \begin{tabular}{|l}
$\mathrm{C}$ \\
$\cdot$ \\
$\mathrm{I}$ \\
$\cdot$
\end{tabular} & $\begin{array}{l}\mathbf{C} \\
\cdot \\
\text { I } \\
.\end{array}$ & \\
\hline $\mathbf{R}$ & 5 & $\begin{array}{l}\cdot \\
0 \\
7\end{array}$ & $\begin{array}{l}0 \\
\cdot \\
0 \\
7 \\
8\end{array}$ & & $X$ & \\
\hline I & $\begin{array}{l}1 \\
2\end{array}$ & 2 & $\begin{array}{l}0 \\
. \\
1 \\
6\end{array}$ & & & \\
\hline
\end{tabular}




\begin{tabular}{|c|c|c|c|c|c|c|}
\hline & 1 & 1 & 2 & & & \\
\hline $\mathbf{A}$ & $\begin{array}{l}0 \\
. \\
1 \\
5 \\
7\end{array}$ & $\begin{array}{l}2 \\
5\end{array}$ & $\begin{array}{l}0 \\
. \\
1 \\
8 \\
0\end{array}$ & & & \\
\hline $\begin{array}{l}\mathbf{T} \\
\mathbf{m}\end{array}$ & $\begin{array}{l}\cdot \\
2 \\
4 \\
1\end{array}$ & $\begin{array}{l}4 \\
7\end{array}$ & $\begin{array}{l}0 \\
. \\
2 \\
2 \\
1\end{array}$ & $X$ & $X$ & $X$ \\
\hline $\mathbf{L}$ & $\begin{array}{l}0 \\
. \\
2 \\
6 \\
1\end{array}$ & $\begin{array}{l}\cdot \\
3 \\
3\end{array}$ & $\begin{array}{l}0 \\
. \\
2 \\
3 \\
3\end{array}$ & $X$ & & \\
\hline $\begin{array}{c}\mathbf{T} \\
\mathbf{b}\end{array}$ & $\begin{array}{l}0 \\
. \\
4 \\
6 \\
5\end{array}$ & $\begin{array}{l}\cdot \\
4 \\
4\end{array}$ & $\begin{array}{l}J \\
3 \\
3 \\
3 \\
9\end{array}$ & & $X$ & $X$ \\
\hline $\mathbf{H}$ & $\begin{array}{l}0 \\
. \\
6 \\
0 \\
6\end{array}$ & $\begin{array}{l}0 \\
4\end{array}$ & $\begin{array}{l}0 \\
. \\
4 \\
5 \\
8\end{array}$ & & $X$ & \\
\hline $\begin{array}{l}\text { M } \\
\text { o }\end{array}$ & $\begin{array}{l}0 \\
. \\
6 \\
8 \\
5\end{array}$ & $\begin{array}{l}7 \\
4 \\
3\end{array}$ & $\begin{array}{l}2 \\
0 \\
. \\
7 \\
4 \\
9 \\
\end{array}$ & & $X$ & $X$ \\
\hline $\mathbf{E}$ & 0 & 8 & $\begin{array}{l}0 \\
\\
5\end{array}$ & $X$ & $X$ & $X$ \\
\hline
\end{tabular}




\begin{tabular}{|c|c|c|c|c|c|c|}
\hline & $\begin{array}{l}8 \\
4\end{array}$ & $\begin{array}{l}3 \\
8\end{array}$ & $\begin{array}{l}6 \\
3\end{array}$ & & & \\
\hline $\begin{array}{l}\text { C } \\
\text { d }\end{array}$ & $\begin{array}{l}\cdot \\
9 \\
3\end{array}$ & 1 & $\begin{array}{l}1 \\
. \\
2 \\
4 \\
3\end{array}$ & & & \\
\hline $\begin{array}{l}\mathbf{S} \\
\mathbf{b}\end{array}$ & $\begin{array}{l}8 \\
5 \\
6\end{array}$ & 5 & $\begin{array}{l}0 \\
. \\
6 \\
8 \\
8\end{array}$ & & & \\
\hline $\begin{array}{l}\mathbf{Y} \\
\mathbf{b}\end{array}$ & 9 & $\begin{array}{l}2 \\
5\end{array}$ & $\begin{array}{l}\cdot \\
6 \\
2\end{array}$ & $x$ & $X$ & X \\
\hline $\begin{array}{l}\mathbf{E} \\
\mathbf{r}\end{array}$ & $\begin{array}{l}9 \\
5\end{array}$ & $\begin{array}{l}7 \\
2\end{array}$ & $\begin{array}{l}5 \\
9\end{array}$ & & & \\
\hline $\begin{array}{l}\mathbf{T} \\
\mathbf{a}\end{array}$ & $\begin{array}{l}2 \\
7\end{array}$ & 6 & $\begin{array}{l}1 \\
4 \\
4 \\
4\end{array}$ & & & \\
\hline $\mathbf{U}$ & 4 & 9 & $\begin{array}{l}2 \\
5 \\
5 \\
8\end{array}$ & & & \\
\hline $\begin{array}{l}\text { G } \\
\mathrm{e}\end{array}$ & $\begin{array}{l}\cdot \\
5 \\
4\end{array}$ & $\begin{array}{l}4 \\
0\end{array}$ & $\begin{array}{l}3 \\
0 \\
0 \\
2\end{array}$ & & & \\
\hline G & 3 & 4 & 1 & $X$ & & \\
\hline
\end{tabular}




\begin{tabular}{|c|c|c|c|c|c|c|}
\hline d & 0 & $\begin{array}{l}0 \\
4\end{array}$ & $\begin{array}{l}9 \\
1\end{array}$ & & & \\
\hline $\begin{array}{l}\mathbf{D} \\
\mathbf{y}\end{array}$ & 1 & $\begin{array}{l}2 \\
\cdot \\
8 \\
2\end{array}$ & $\begin{array}{l}2 \\
. \\
4\end{array}$ & & & \\
\hline $\begin{array}{l}\mathbf{S} \\
\mathbf{m}\end{array}$ & $\begin{array}{l}0 \\
5 \\
\end{array}$ & $\begin{array}{l}3 \\
\cdot \\
5 \\
3 \\
\end{array}$ & $\begin{array}{l}3 \\
. \\
0 \\
3\end{array}$ & & & \\
\hline $\begin{array}{l}\mathrm{S} \\
\mathrm{n}\end{array}$ & $\begin{array}{l}6 \\
5\end{array}$ & $\begin{array}{l}5 \\
\cdot \\
4 \\
0\end{array}$ & $\begin{array}{l}2 \\
. \\
6 \\
0\end{array}$ & $\mathrm{X}$ & $\mathrm{X}$ & \\
\hline $\begin{array}{l}\text { H } \\
\text { f }\end{array}$ & 7 & $\begin{array}{l}4 \\
\cdot \\
8 \\
3 \\
\end{array}$ & $\begin{array}{l}3 \\
8 \\
8\end{array}$ & $X$ & $X$ & $X$ \\
\hline $\begin{array}{l}\mathbf{P} \\
\mathbf{r}\end{array}$ & 7 & $\begin{array}{l}5 \\
\cdot \\
6 \\
1\end{array}$ & $\begin{array}{l}4 \\
6 \\
6 \\
3\end{array}$ & $\mathrm{X}$ & $\mathrm{X}$ & \\
\hline $\begin{array}{l}\text { T } \\
\mathbf{h}\end{array}$ & $\begin{array}{l}1 \\
2\end{array}$ & $\begin{array}{l}1 \\
1 \\
8 \\
8\end{array}$ & $\begin{array}{l}1 \\
0 \\
3\end{array}$ & & $\mathrm{X}$ & $X$ \\
\hline $\begin{array}{l}\mathbf{P} \\
\mathbf{b}\end{array}$ & $\begin{array}{l}1 \\
3\end{array}$ & $\begin{array}{l}1 \\
5 \\
\cdot \\
0\end{array}$ & $\begin{array}{l}7 \\
7\end{array}$ & & $X$ & $X$ \\
\hline $\begin{array}{l}\mathbf{G} \\
\mathbf{a}\end{array}$ & 1 & $\begin{array}{l}1 \\
8 \\
6 \\
6\end{array}$ & $\begin{array}{l}1 \\
9 \\
0 \\
0\end{array}$ & & $\mathrm{X}$ & \\
\hline
\end{tabular}




\begin{tabular}{|c|c|c|c|c|c|c|}
\hline C & 1 & $\begin{array}{l}1 \\
2 \\
. \\
0\end{array}$ & $\begin{array}{l}1 \\
2 \\
. \\
8\end{array}$ & & & \\
\hline $\mathbf{Y}$ & 1 & $\begin{array}{l}6 \\
.\end{array}$ & $\begin{array}{l}1 \\
4 \\
6 \\
6\end{array}$ & & $X$ & \\
\hline $\mathbf{N}$ & 7 & $\begin{array}{l}0 \\
.\end{array}$ & $\begin{array}{l}1 \\
7 \\
. \\
2\end{array}$ & $X$ & $X$ & $X$ \\
\hline $\mathbf{N}$ & 0 & $\begin{array}{l}6 \\
. \\
0\end{array}$ & $\begin{array}{l}1 \\
5\end{array}$ & & & \\
\hline
\end{tabular}

Table 5. continued.

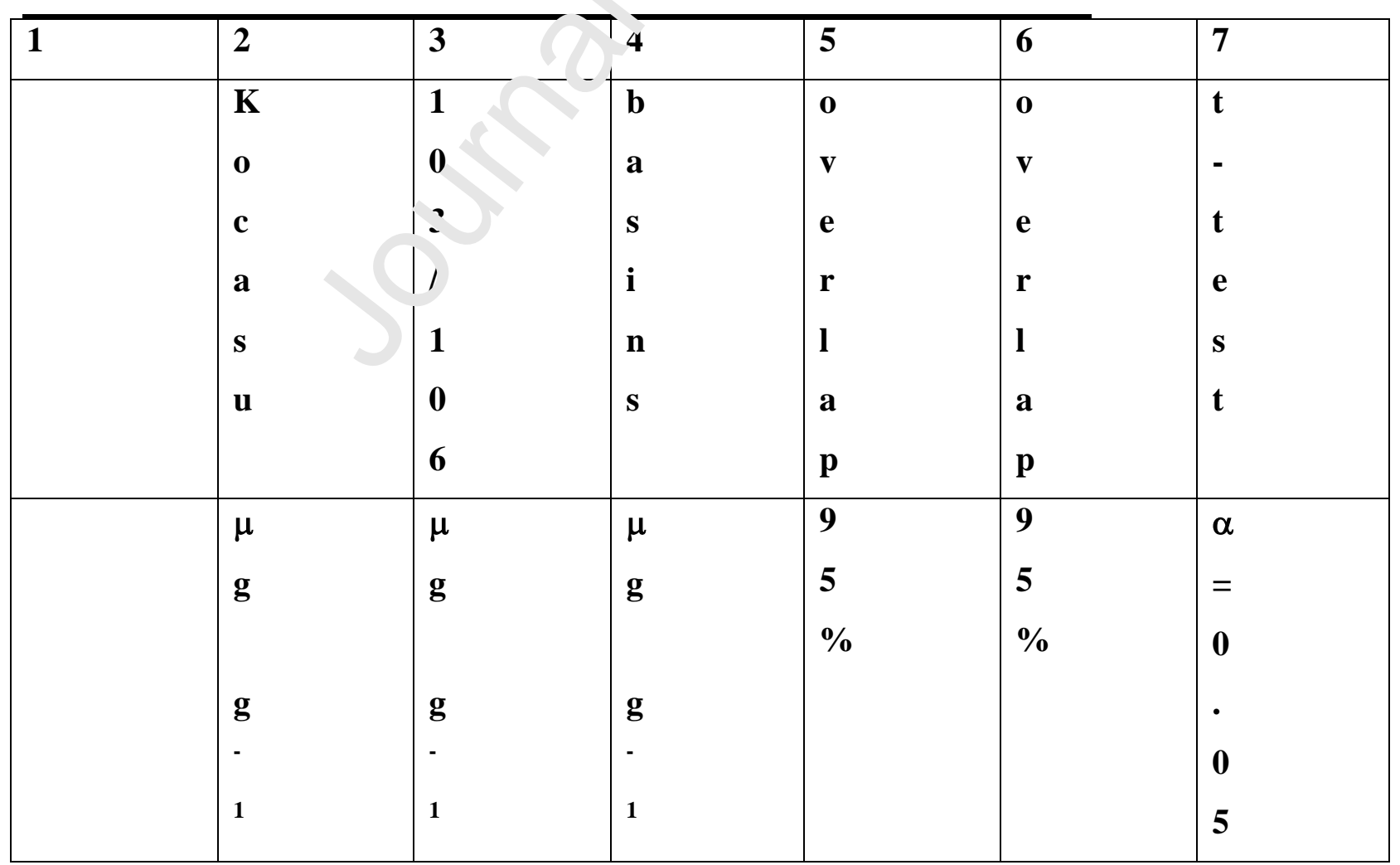




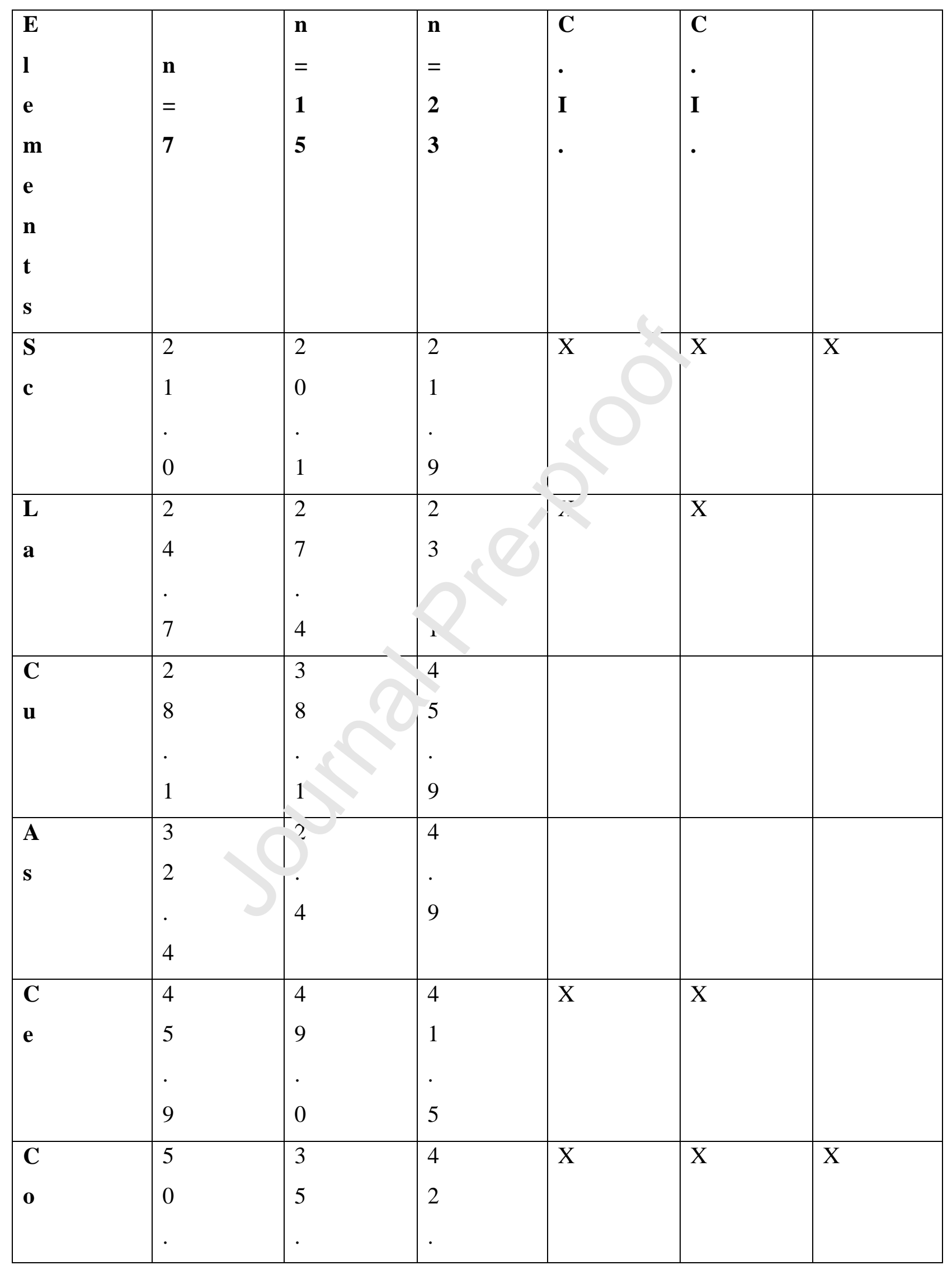




\begin{tabular}{|c|c|c|c|c|c|c|}
\hline & 9 & 9 & 8 & & & \\
\hline $\begin{array}{l}\mathbf{Z} \\
\mathrm{n}\end{array}$ & $\begin{array}{l}3 \\
.\end{array}$ & $\begin{array}{l}7 \\
5 \\
\cdot \\
3\end{array}$ & $\begin{array}{l}8 \\
1 \\
. \\
2\end{array}$ & & & \\
\hline $\begin{array}{l}\text { R } \\
\mathbf{b}\end{array}$ & 1 & $\begin{array}{l}1 \\
3 \\
5\end{array}$ & $\begin{array}{l}1 \\
4 \\
3\end{array}$ & & & \\
\hline $\mathbf{V}$ & 1 & $\begin{array}{l}1 \\
3 \\
4\end{array}$ & $\begin{array}{l}1 \\
5 \\
0\end{array}$ & $\mathrm{X}$ & $X$ & $\mathrm{X}$ \\
\hline $\begin{array}{l}\mathbf{S} \\
\mathbf{r}\end{array}$ & 1 & $\begin{array}{l}1 \\
2 \\
6\end{array}$ & 8 & & $\mathrm{X}$ & $\mathrm{X}$ \\
\hline $\begin{array}{l}\mathbf{N} \\
\mathbf{i}\end{array}$ & 1 & $\begin{array}{l}1 \\
6 \\
1\end{array}$ & $\begin{array}{l}4 \\
2\end{array}$ & $\mathrm{X}$ & $\mathrm{X}$ & $\mathrm{X}$ \\
\hline $\bar{W}$ & 1 & $\begin{array}{l}7 \\
6\end{array}$ & 5 & $\mathrm{X}$ & & \\
\hline $\begin{array}{l}Z \\
\mathbf{r}\end{array}$ & $\begin{array}{l}8 \\
9\end{array}$ & $\begin{array}{l}1 \\
y \\
0\end{array}$ & 1 & $X$ & $\mathrm{X}$ & $\mathrm{X}$ \\
\hline $\begin{array}{l}\mathrm{C} \\
\mathbf{r}\end{array}$ & 8 & $\begin{array}{l}1 \\
7 \\
1\end{array}$ & 8 & & & \\
\hline $\begin{array}{l}\text { B } \\
\mathbf{a}\end{array}$ & 4 & $\begin{array}{l}3 \\
9 \\
5\end{array}$ & $\begin{array}{l}5 \\
1\end{array}$ & & & \\
\hline $\begin{array}{l}\mathbf{M} \\
\mathbf{n}\end{array}$ & 4 & $\begin{array}{l}2 \\
9\end{array}$ & $\begin{array}{l}3 \\
2\end{array}$ & & & \\
\hline
\end{tabular}




\begin{tabular}{|c|c|c|c|c|c|c|}
\hline & 3 & 4 & 7 & & & \\
\hline $\mathbf{P}$ & $\begin{array}{l}5 \\
1\end{array}$ & $\begin{array}{l}1 \\
7 \\
7\end{array}$ & $\begin{array}{l}7 \\
8 \\
4\end{array}$ & $X$ & & \\
\hline $\begin{array}{l}\text { T } \\
\mathbf{i}\end{array}$ & 3 & $\begin{array}{l}5 \\
5 \\
9 \\
8\end{array}$ & $\begin{array}{l}5 \\
2 \\
2 \\
5\end{array}$ & & & \\
\hline $\begin{array}{l}\mathbf{N} \\
\mathbf{a}\end{array}$ & 0 & $\begin{array}{l}9 \\
6 \\
7\end{array}$ & $\begin{array}{l}6 \\
9 \\
7 \\
8\end{array}$ & & & \\
\hline $\begin{array}{l}\mathbf{C} \\
\mathbf{a}\end{array}$ & 2 & 8 & $\begin{array}{l}1 \\
4 \\
1 \\
9\end{array}$ & & & \\
\hline $\mathbf{K}$ & $\begin{array}{l}8 \\
1 \\
5\end{array}$ & $\begin{array}{l}1 \\
0\end{array}$ & $\begin{array}{l}3 \\
1\end{array}$ & $X$ & $X$ & $\mathrm{X}$ \\
\hline $\begin{array}{l}\text { M } \\
\text { g }\end{array}$ & $\begin{array}{l}1 \\
3\end{array}$ & $\begin{array}{l}9 \\
4\end{array}$ & $\begin{array}{l}1 \\
7 \\
2 \\
8 \\
0\end{array}$ & & & \\
\hline $\begin{array}{l}\mathbf{F} \\
\mathbf{e}\end{array}$ & 4 & 4 & $\begin{array}{l}4 \\
3\end{array}$ & $X$ & $\mathrm{X}$ & \\
\hline
\end{tabular}




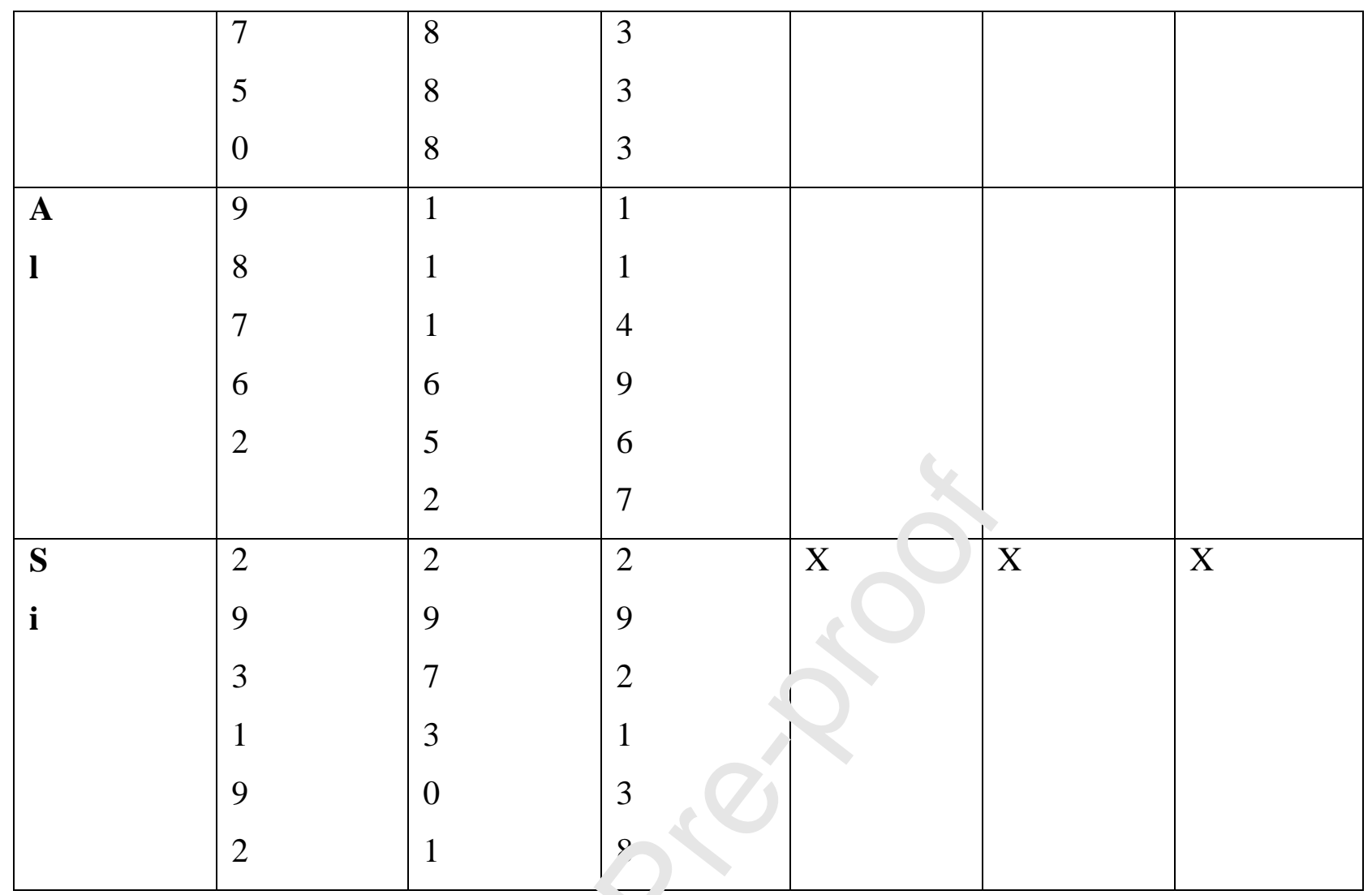

Table 6.

\begin{tabular}{|l|l|l|}
\hline Age span & Underlying cause \\
\hline (cal ka) & 17.2-15.7 & $\begin{array}{l}\text { Melting of Scandinavian ice } \\
\text { sheet swells Neoeuxine Lake } \\
\text { which spills southward into } \\
\text { the Marmara Sea and onward } \\
\text { to the Aegean Sea. Levels } \\
\text { were, respectively, } \sim-35 \mathrm{~m},- \\
73 \text { m and }-120 \mathrm{~m} .\end{array}$ \\
\hline $\mathbf{1 5 . 7 - 1 3 . 8}$ & Subaerial & $\begin{array}{l}\text { Evaporative drawdown of } \\
\text { Marmara Sea to } \sim 84 \mathrm{~m} . \\
\text { Propontis valley Lake phase } \\
\text { begins. }\end{array}$ \\
\hline $\mathbf{1 3 . 8}$-13.2 & $100 \% \mathrm{NE}$ & $\begin{array}{l}\text { Rising global ocean overtops } \\
\text { the Dardanelles sill, quickly } \\
\text { raising the level of the } \\
\text { Marmara Sea from } \sim-84 \mathrm{~m} \text { to } \\
\sim-60 \text { m. Only } \sim 140 \mathrm{~km}{ }^{3}\end{array}$ \\
& & $\begin{array}{l}\text { would have been required, } \\
\sim 75 \% \text { of this pooling in the }\end{array}$ \\
\hline
\end{tabular}




\begin{tabular}{|c|c|c|}
\hline & & $\begin{array}{l}\text { Tekirda } \breve{g} \text { Basin. The } \\
\text { Marmara Sea became an } \\
\text { embayment of the Aegean } \\
\text { Sea. }\end{array}$ \\
\hline 〜3.2-11.1 & $50: 50$ & $\begin{array}{l}\text { Slow and weak density-driven } \\
\text { exchange of saline Aegean } \\
\text { water but a trickle for } \\
\text { brackish residual Propontis } \\
\text { Lake water, in equal amounts, } \\
\text { as base level in the Marmara } \\
\text { Sea rises slowly from } \sim-60 \mathrm{~m} \\
\ldots \sim-43 \mathrm{~m} \text {. }\end{array}$ \\
\hline $11.1-10.2$ & $100 \% \mathrm{SW}$ & $\begin{array}{l}\text { Vo ous outflow from the } \\
\text { Ne seuxine Lake (at } \sim-35 \mathrm{~m} \\
\text { elevation) into the Marmara } \\
\text { Sea (at }-43 \mathrm{~m} \text { rising to } \sim-35 \\
\mathrm{~m} \text { ) caused by increased } \\
\text { central Asian and European } \\
\text { river discharges and possible } \\
\text { glacial-lake outburst floods. } \\
\text { Entry of Aegean water was } \\
\text { blocked by this outflow as it } \\
\text { continued southwestward } \\
\text { through the Strait of } \\
\text { Dardanelles. }\end{array}$ \\
\hline $10.2-9.4$ & $10 \tilde{u}$ & $\begin{array}{l}\text { Weakening Neoeuxine Lake } \\
\text { outflow is lifted off the floor } \\
\text { of the Strait of Bosphorus as } \\
\text { a 'salt wedge' penetrates up } \\
\text { that strait against the surface } \\
\text { brackish outflow. With no } \\
\text { entry of saline water into the } \\
\text { Neoeuxine Lake, flow } \\
\text { through the Strait of } \\
\text { Dardanelles continues to be } \\
\text { entirely toward the Aegean } \\
\text { Sea. }\end{array}$ \\
\hline \multirow[t]{2}{*}{ 9.4-8.0 } & $>80 \% \mathrm{SW}$ & $\begin{array}{l}\text { Significant but episodic } \\
\text { intrusion of saline water into } \\
\text { the Black Sea }\end{array}$ \\
\hline & $<20 \% \mathrm{NE}$ & $\begin{array}{l}\text { with a large initial pulse } \\
\text { sufficient to sharply raise the } \\
{ }^{87} \mathrm{Sr} /{ }^{86} \mathrm{Sr} \text { ratio but not to } \\
\text { elevate salinity enough to } \\
\text { accommodate euryhaline }\end{array}$ \\
\hline
\end{tabular}




\begin{tabular}{|c|c|c|}
\hline & & $\begin{array}{l}\text { faunas. Aegean water started } \\
\text { to move northeastward along } \\
\text { the floor of the Dardanelles. }\end{array}$ \\
\hline \multirow[t]{2}{*}{$8.0-7.5$} & $<80 \% \mathrm{SW}$ & $\begin{array}{l}\text { Establishment of two-way } \\
\text { flow in both straits and } \\
\text { eventual }\end{array}$ \\
\hline & $>20 \% \mathrm{NE}$ & $\begin{array}{l}\text { colonizing of the Black Sea } \\
\text { by euryhaline molluscs and } \\
\text { ostracods. }\end{array}$ \\
\hline \multirow[t]{2}{*}{ 7.5-today } & $\sim 67 \% \mathrm{SW}$ & $\begin{array}{l}\text { Modern two-way flow, so in } \\
\text { the Strait of Dardanelles } \\
\end{array}$ \\
\hline & $\sim 33 \% \mathrm{NE}$ & $\begin{array}{l}\mathrm{s}-3 y \text { water runs } \\
\cdots \text { cheastward along the } \\
\text { jottom }\left(5-25 \mathrm{~cm} \mathrm{~s}^{-1}\right) \text { and } \\
\text { predominantly Black Sea } \\
\mathrm{S}=20 \text { water exits to the } \\
\text { Aegean Sea as an } \sim 30 \mathrm{~m}- \\
\text { thick surface layer }(10-30 \mathrm{~cm} \\
\left.\mathrm{s}^{-1}\right) \text {. }\end{array}$ \\
\hline
\end{tabular}

Declaration of interests

The authors declare that they have no knowı, -ompeting financial interests or personal relationships that could have appeared to influence tl $e^{\prime} v_{k}{ }^{-k} k$ reported in this paper.

The authors declare the following f $n_{\mathrm{c}}$ ncial interests/personal relationships which may be considered as potential competing interests: 


\section{Highlights}

- Latest Pleistocene-Holocene Unit 1 forms a blanket of $43-47 \mathrm{~km}^{3}$ in Marmara Sea

- Kocasu River and its tributaries can account for 85-90\% of the volume of Unit 1

- Sediment budget calculations rely on data from gauging stations and BQART model

- Isolated Marmara basins allow reliable quantification of the sedimentary budget 


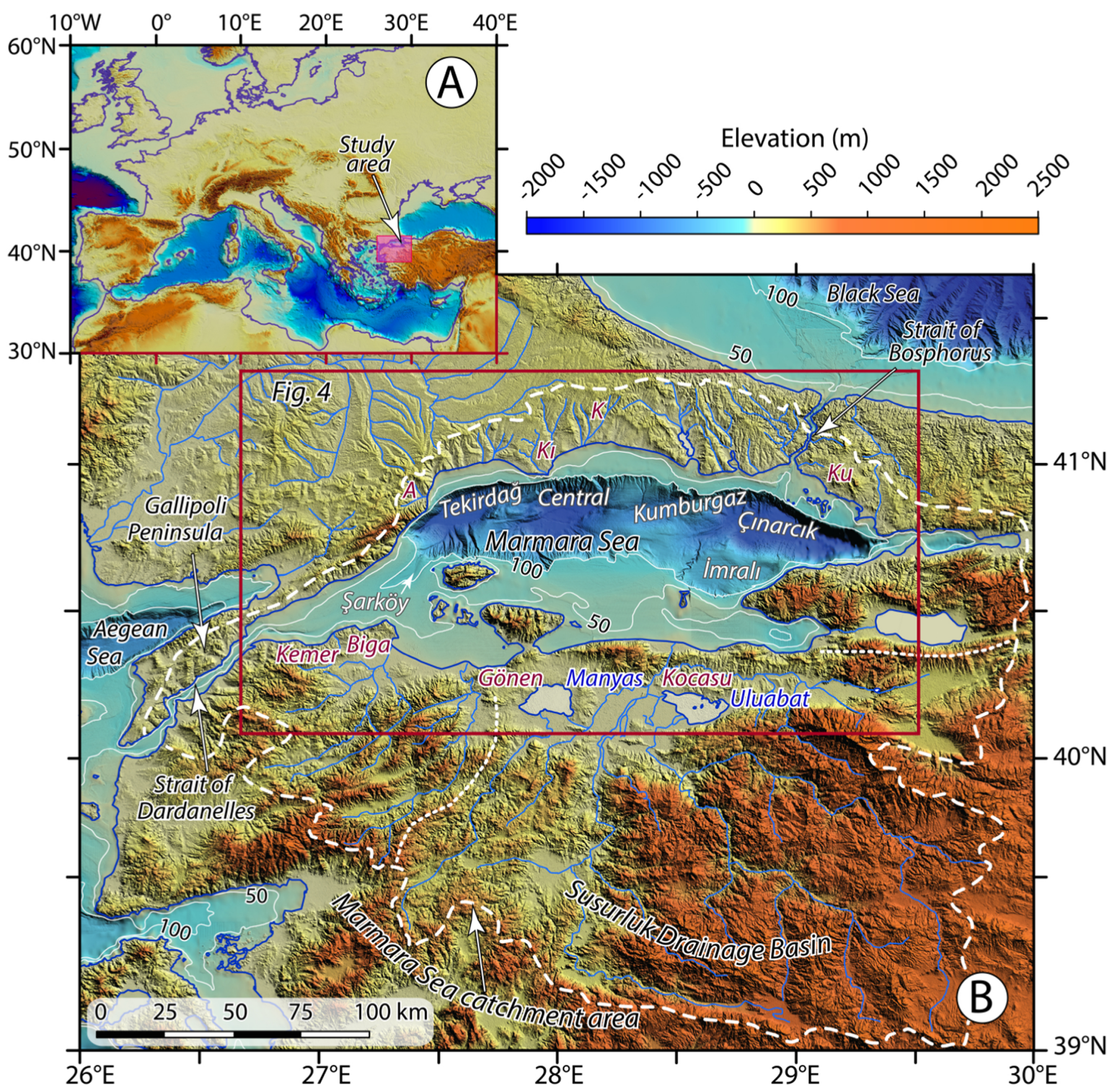

Figure 1 


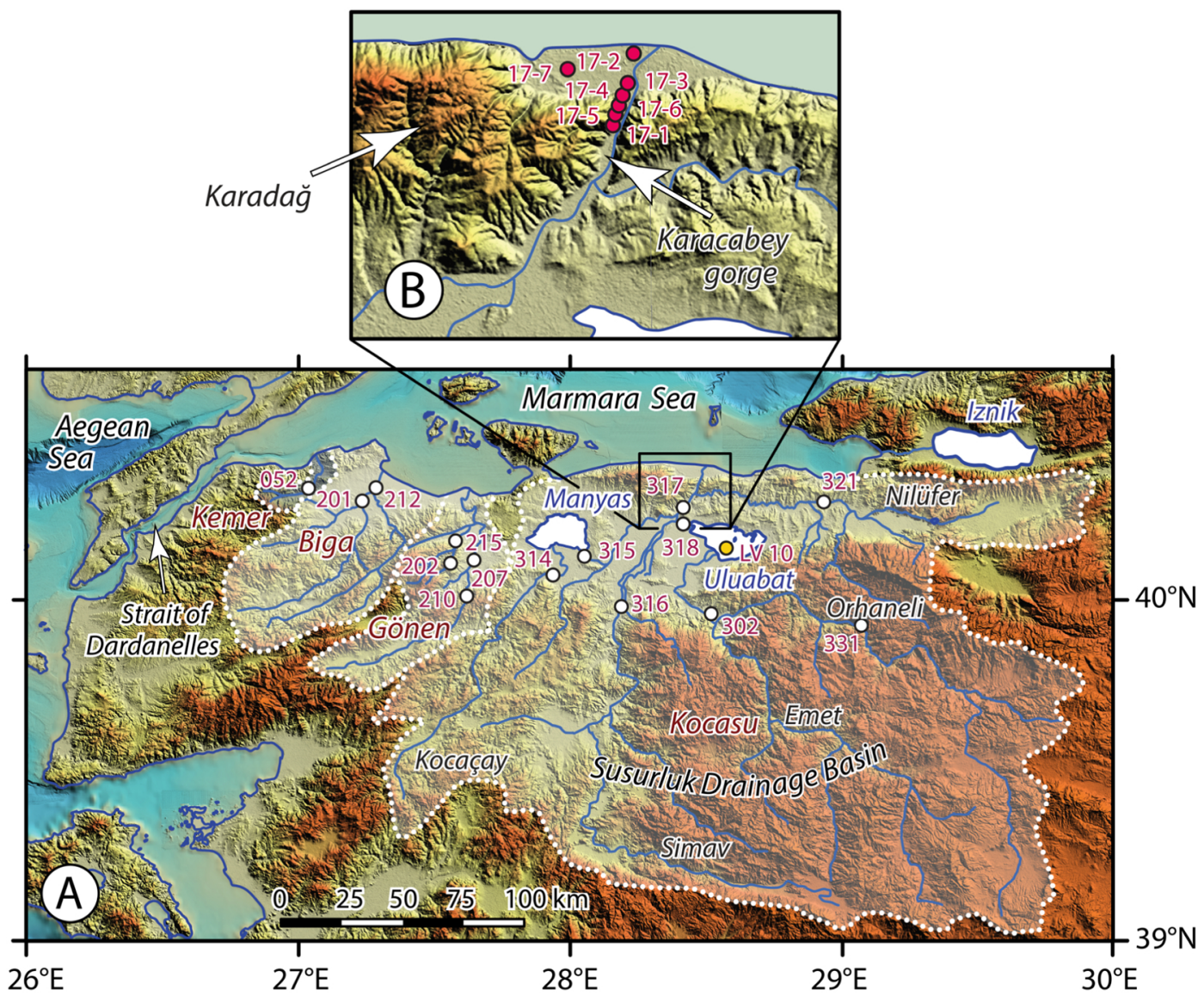

Figure 2 


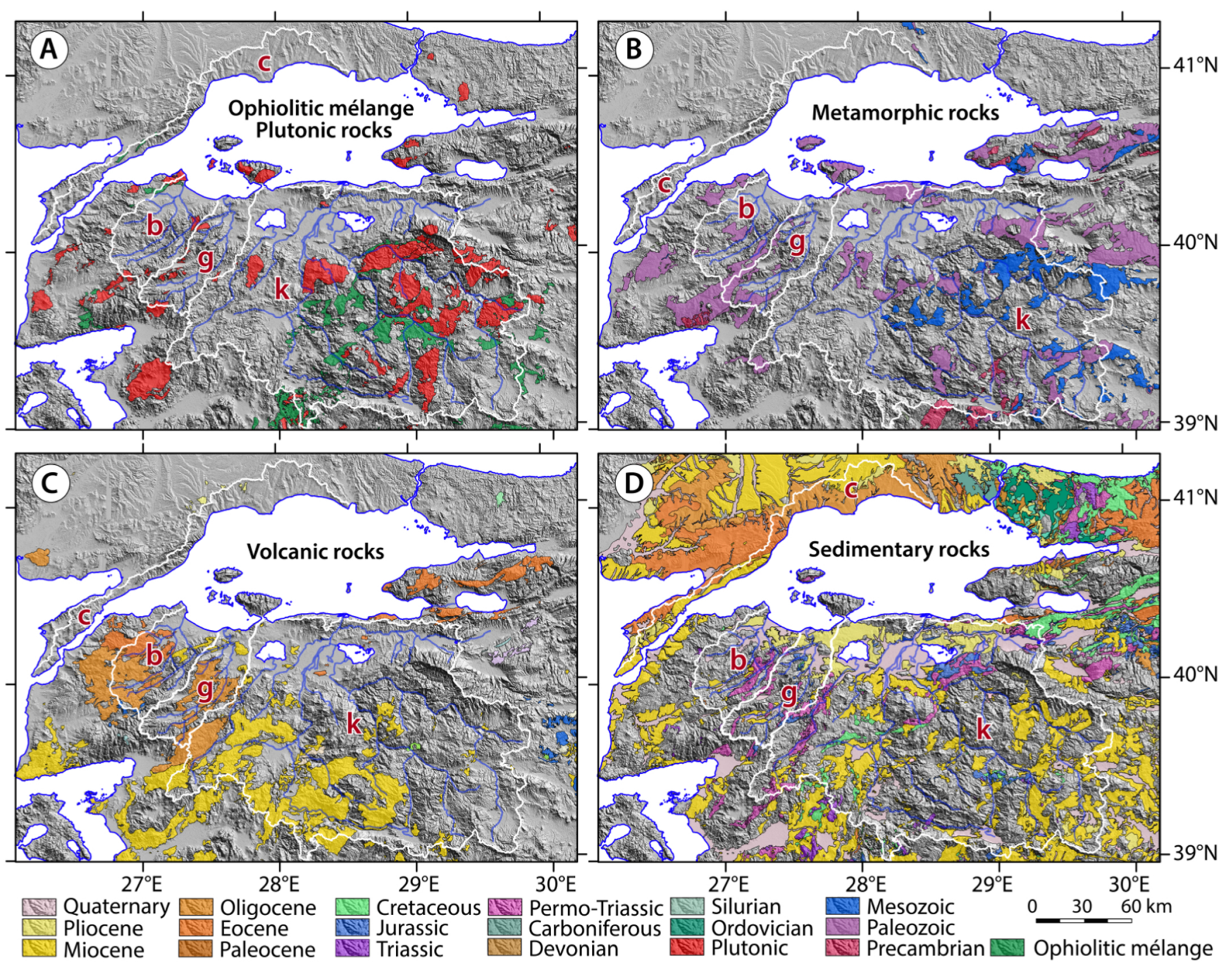

Figure 3 


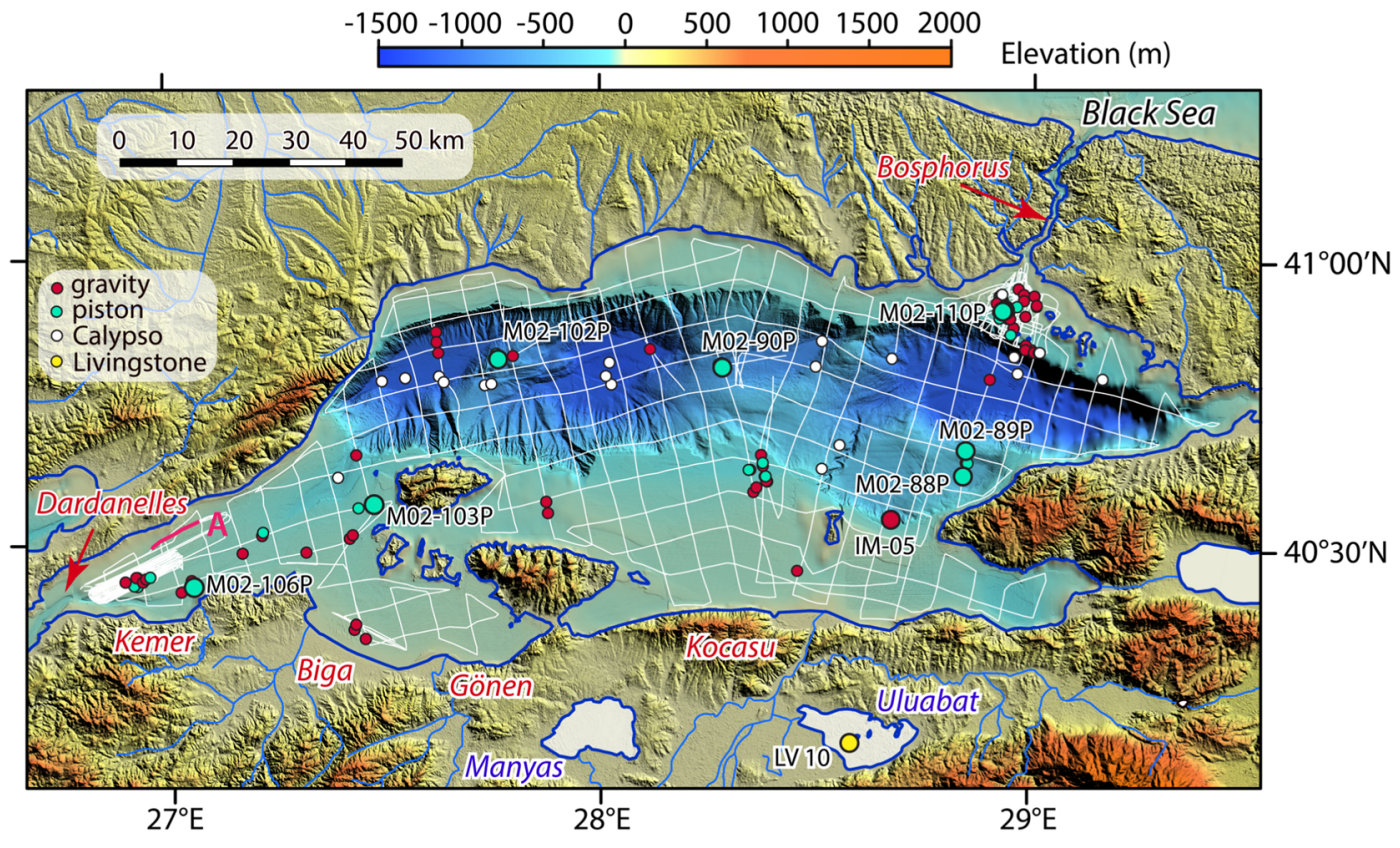

Figure 4 

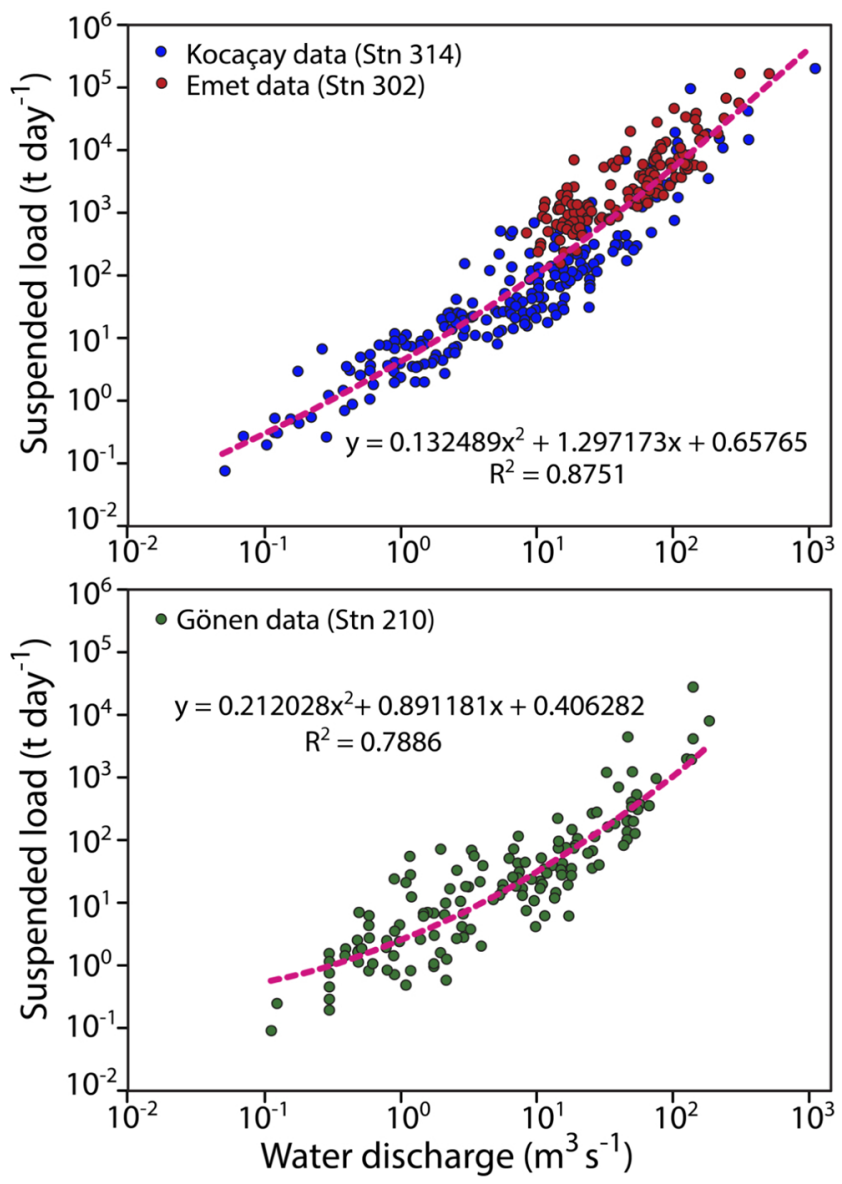

Figure 5 


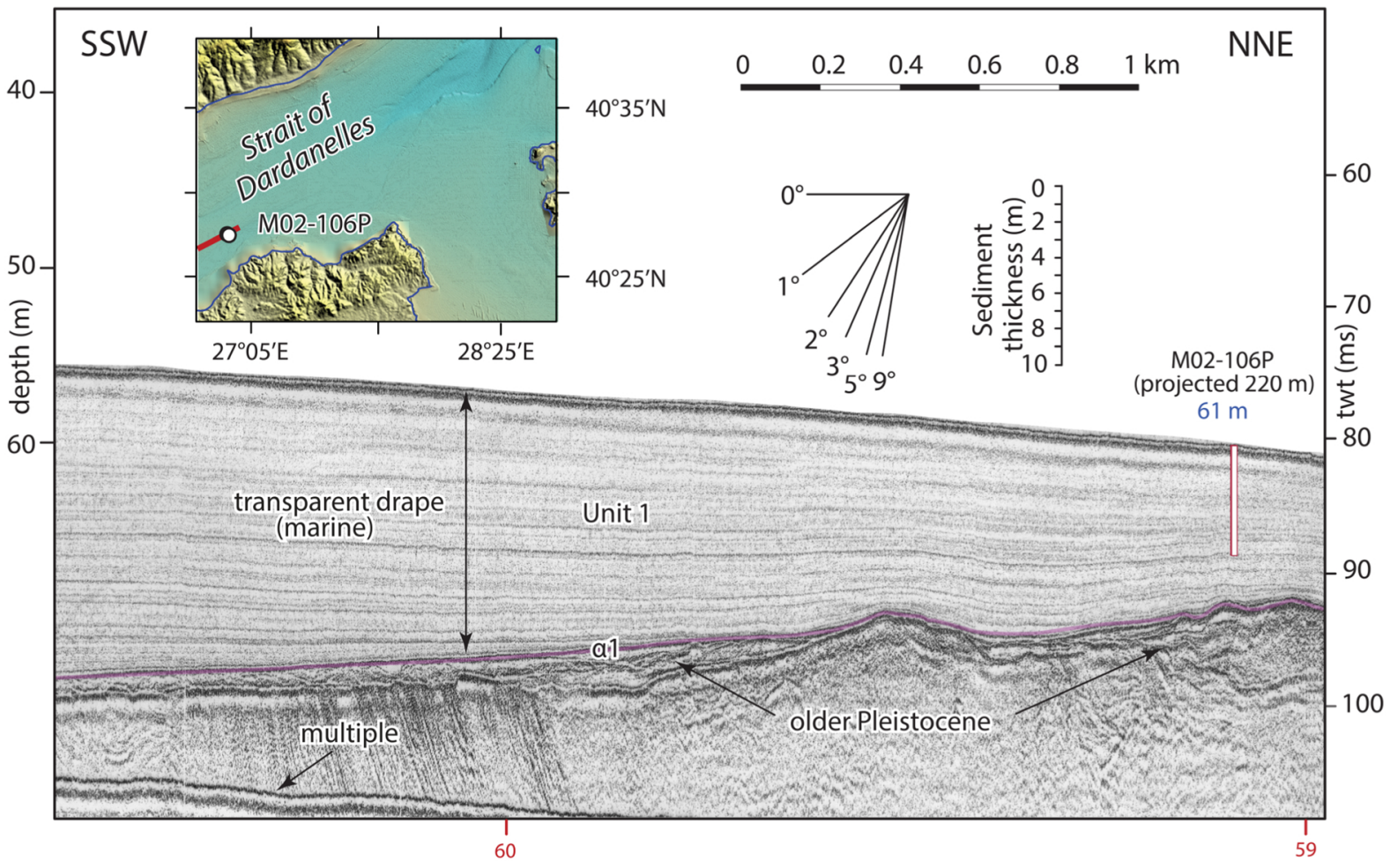

Figure 6 


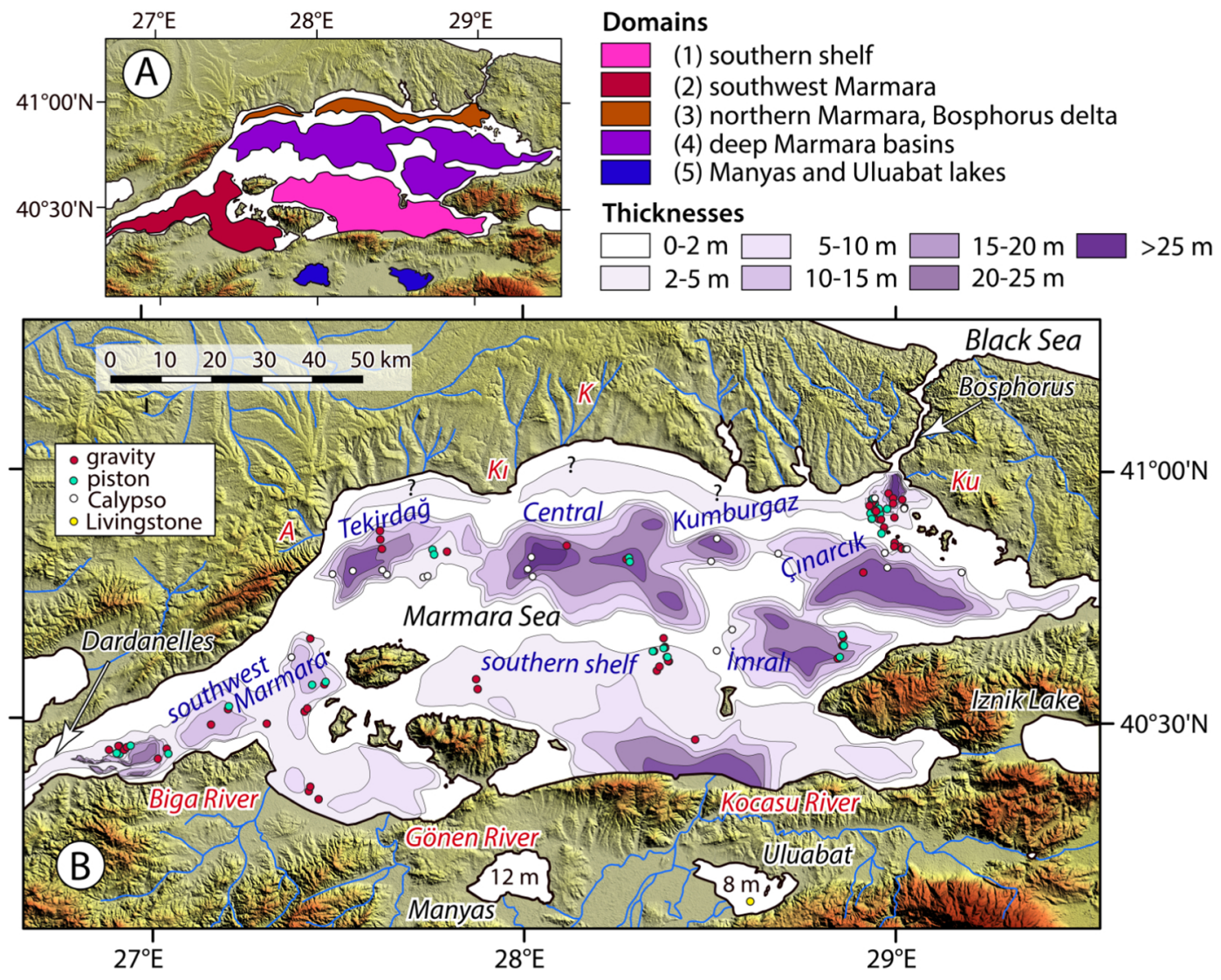

Figure 7 


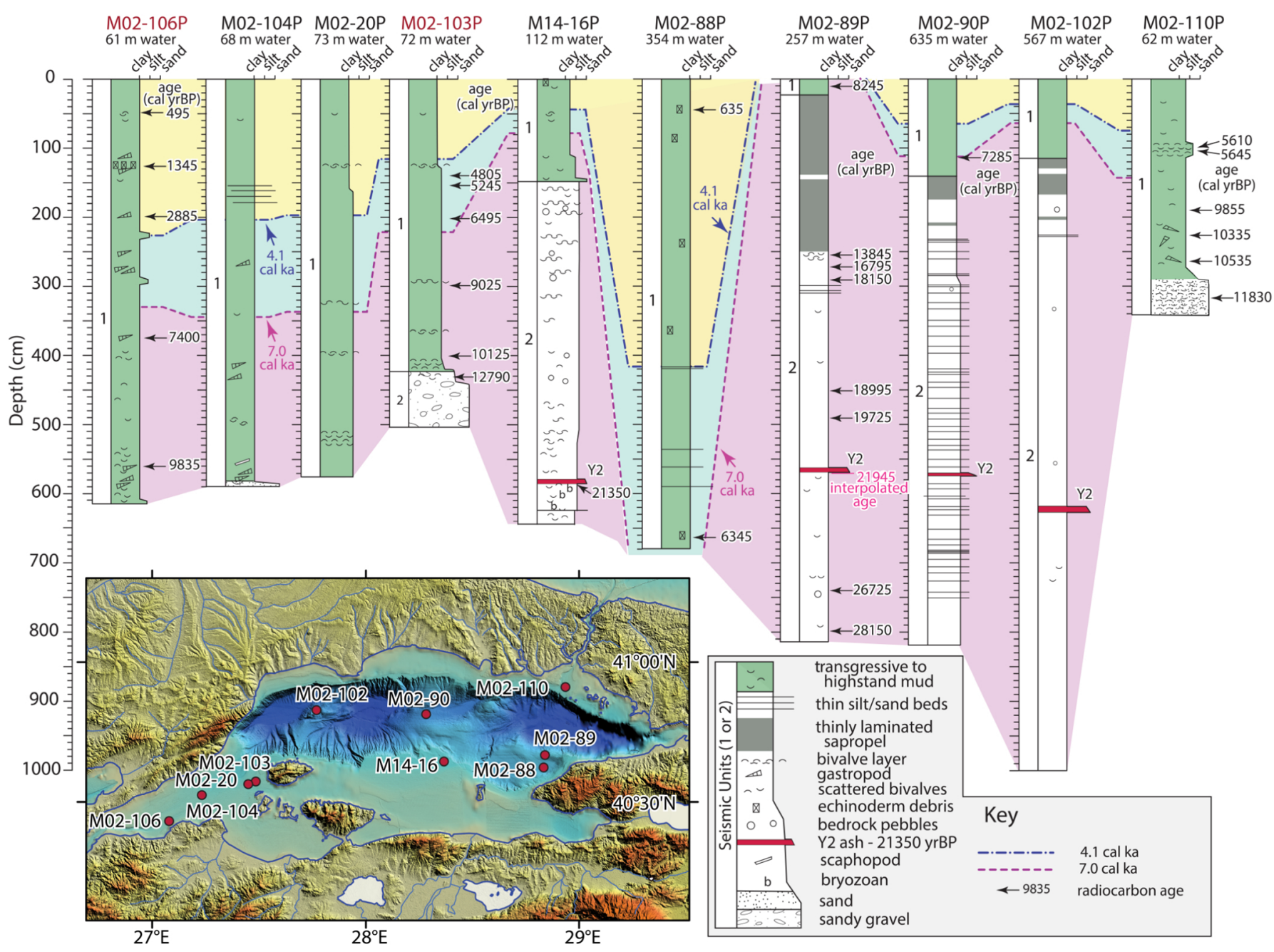

Figure 8 


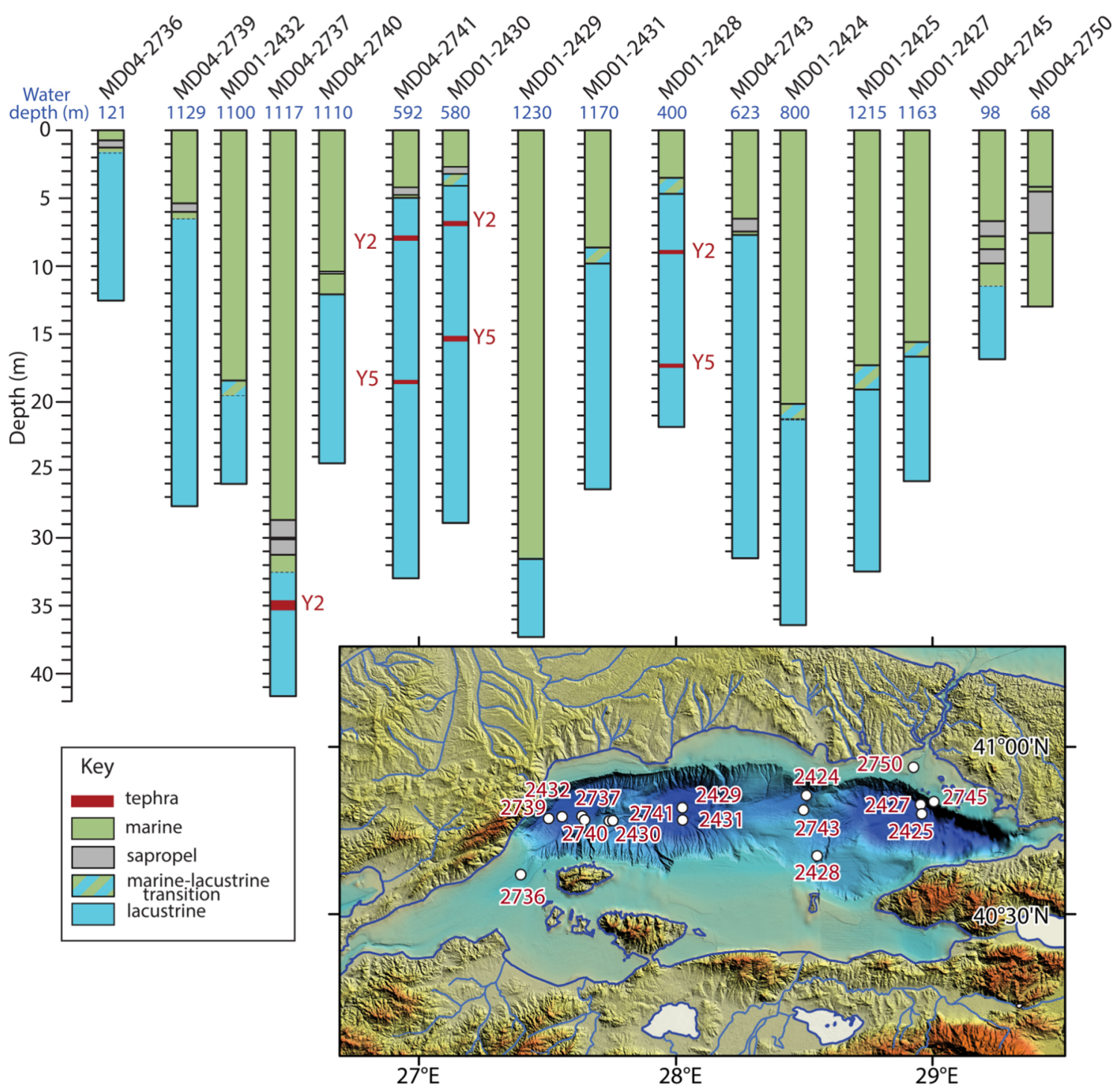

Figure 9 


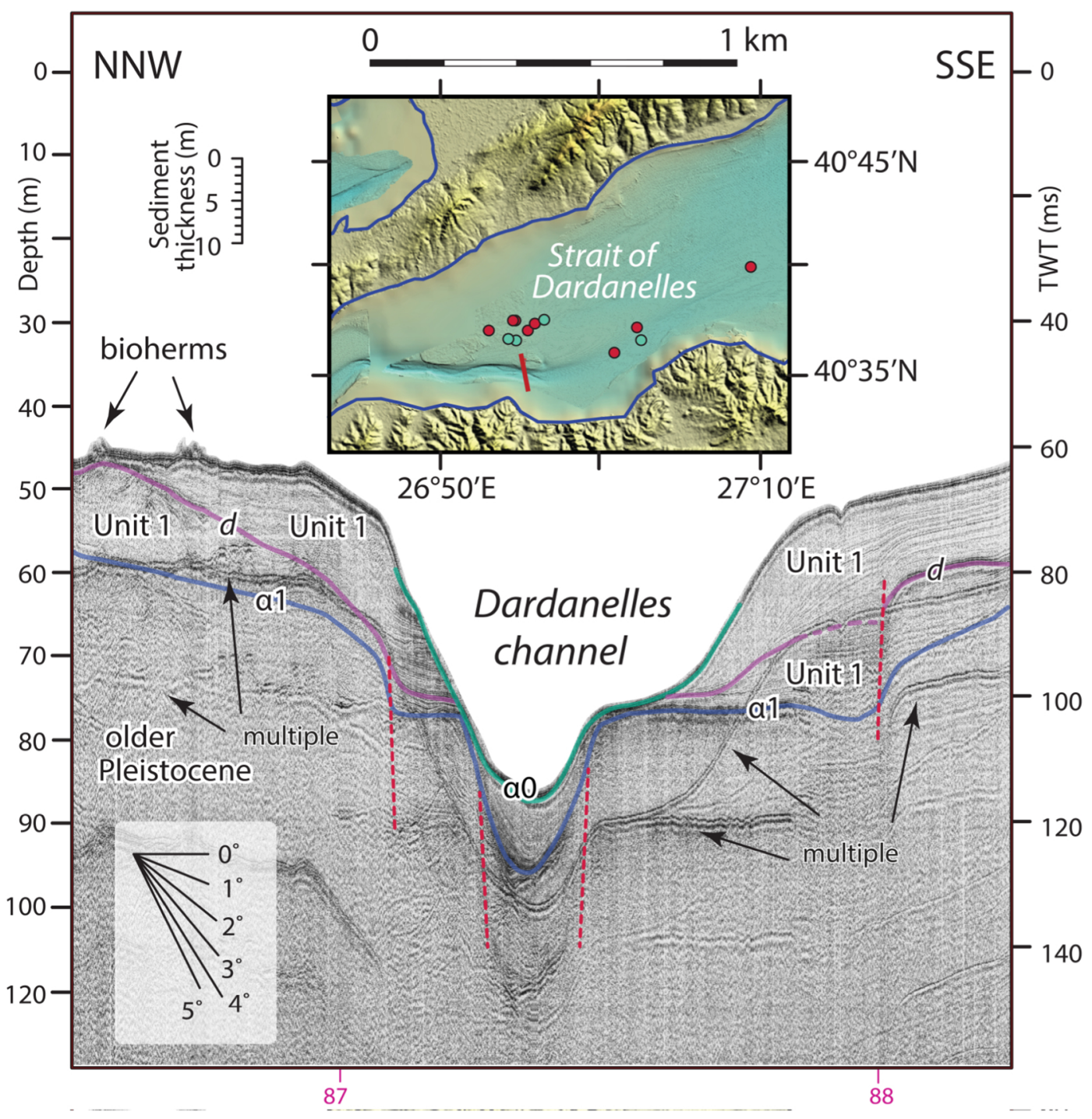

Figure 10 


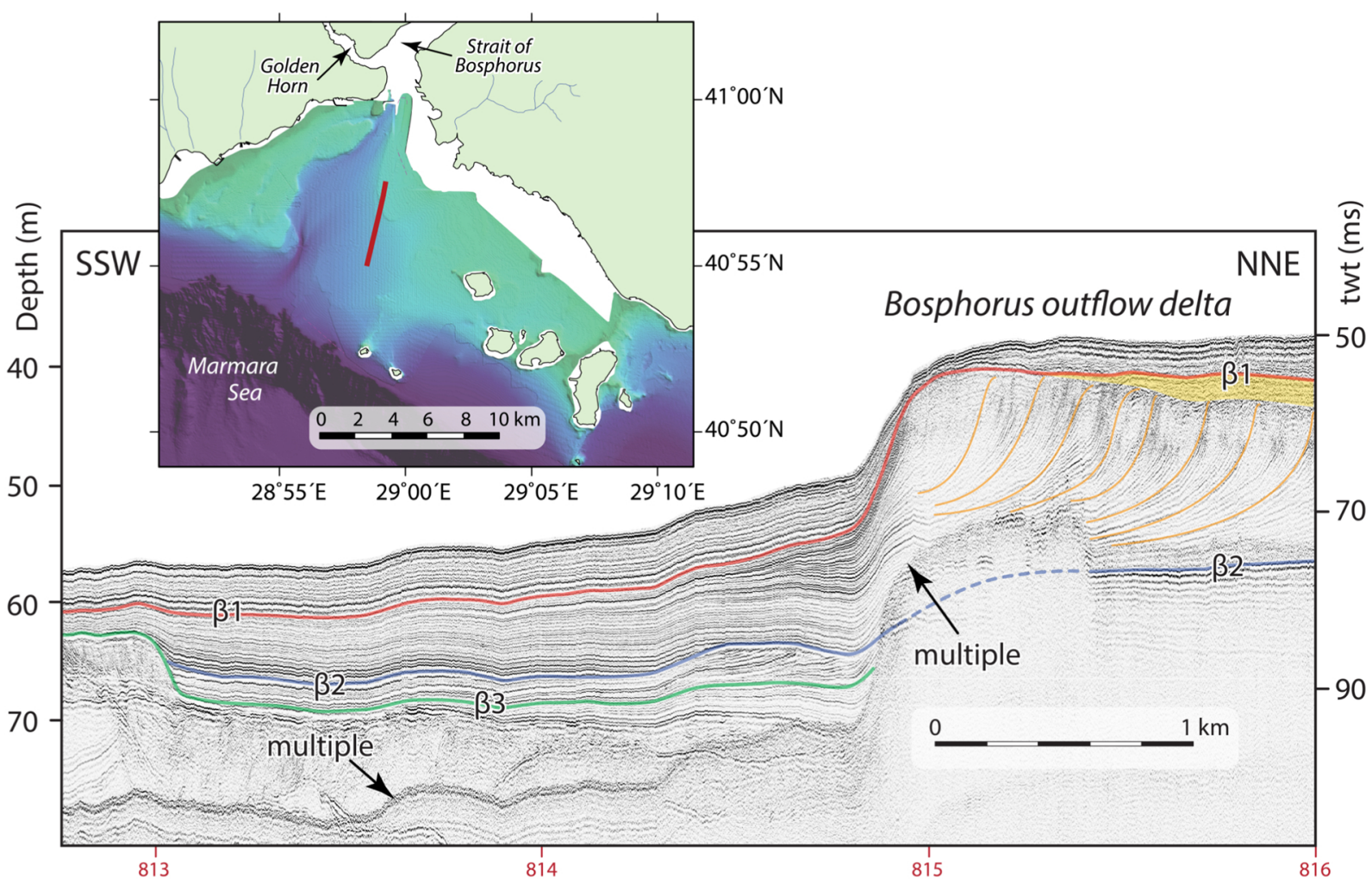

Figure 11 


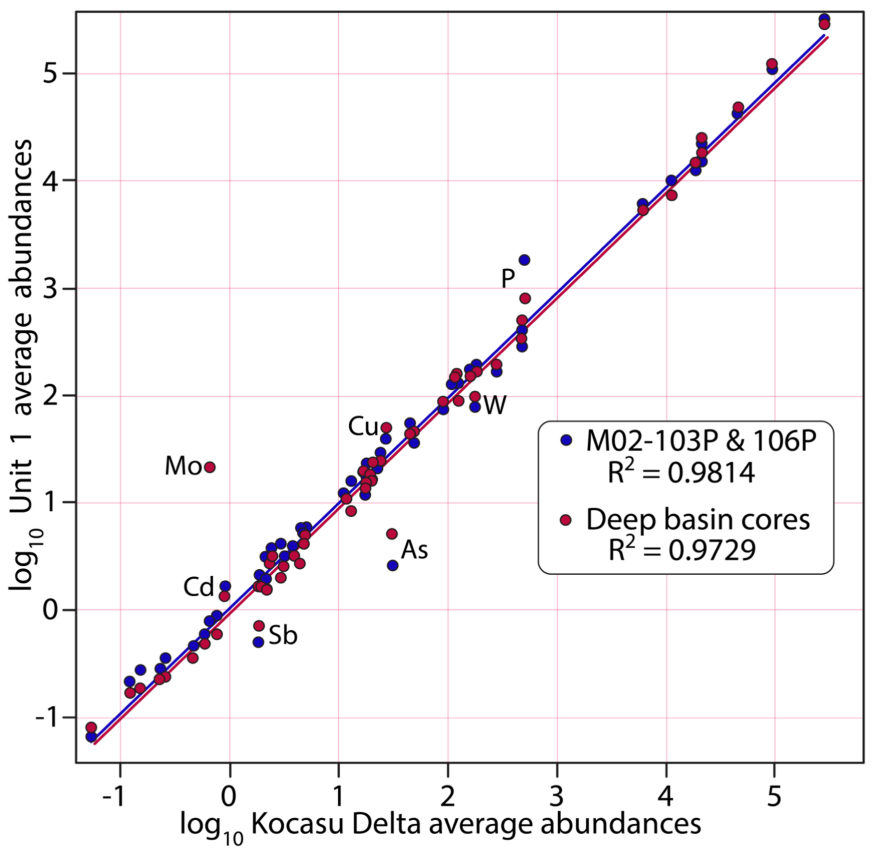

Figure 12 